

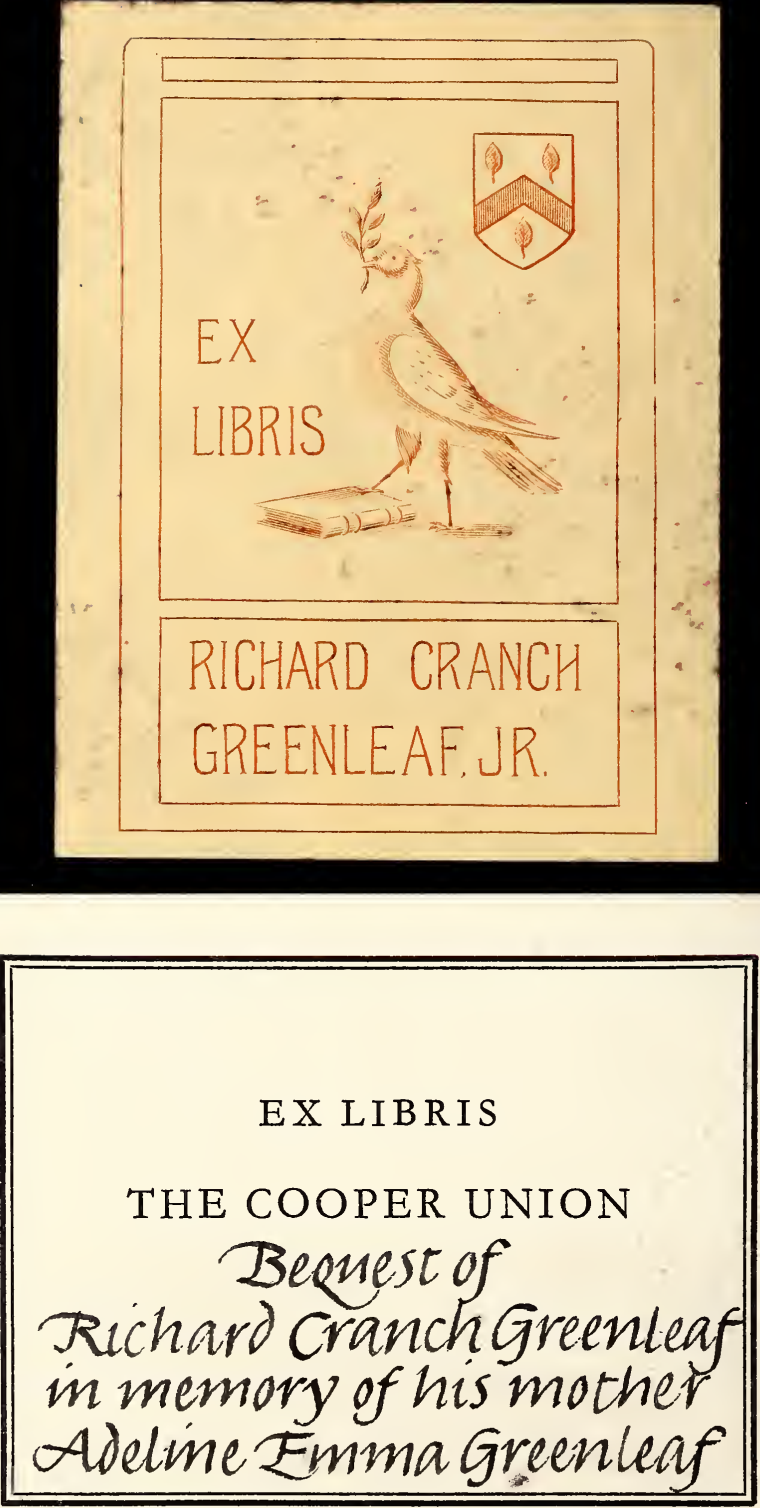
13.50 


OLD FRENCH PLATE:

A HANDBOOK FOR THE COLLECTOR. 









\section{OLD FRENCH PLATE}

ITS MAKERS AND MARKS.

By WILFRED JOSEPH CRIPPS, C.B., F.S.A. AUthoR OF "OLD ENGLISH PLATE,' ETC., ETC.

SECOND EDITION.

WITH ILLUSTRATIONS.

LONDON :

JOHN MURRAY, ALBEMARLE STREET. 1893 , 

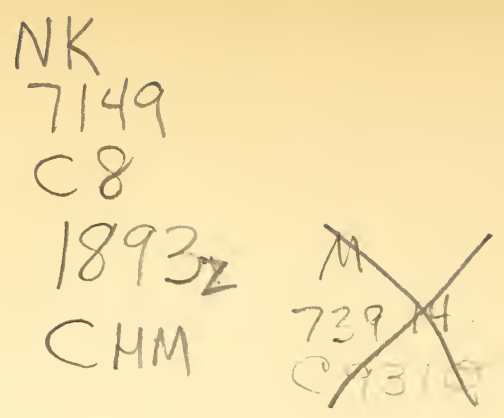

BY THE SAME AUTHOR.

OLD ENGLish PLATE: Ecclesiastical, Decoratrve, and Domestic; its Makers and Marks. With Improved Tables of the Date Letters used in England, Scotland, and Ireland. With 117 Illustrations. Fourth Edition. Medium 8vo. 21s.

\section{6}




\section{PREFACE.}

The high esteem in which old French plate is held amongst connoisseurs and collectors at home and abroad renders a knowledge of the ancient marks used to distinguish it as genuine, desirable and even necessary.

The comparatively modern marks placed upon French plate since the Revolution are well known, having been published both in France and in England. But whilst these, which are of little interest, have been so often printed, no attempt had been made until the appearance of the first edition of the present treatise to interpret the marks by which the beautiful works of the old French goldsmiths may be identified.

Many mistakes must needs occur when an art subject is first dealt with by a foreign author: but even allowing for these, the complete exhaustion of the first edition and the demand for a new one of Old French Plate is some proof that it has been a useful handbook; and it is hoped that the many corrections and additions which have been made in the present edition will enable the reader better than before, to fix the date of almost every 
specimen of old plate made in Paris, and the origin of a good deal of the old provincial French plate, which he has the opportunity of examining.

The author wishes to acknowledge his indebtedness to all the best works on the subject of French gold and silver-work, including those of Labarte, de Laborde, Lacroix, Lasteyrie, Germain Bapst and Eudel, and especially to the works of that celebrated expert the Baron Jérôme Pichon, whose catalogue of the Lenoir Don in the Musée du Louvre, and "catalogues raisonnées" of the collections of ancient plate the property of himself and of M. Eudel (prepared for the notable sales in the years 1878 and 1884 at the Hotel Drouot which have so greatly called the attention of collectors to the beauty of old French plate,) are full of the most valuable information.

It has too long been hoped that M. le Baron Pichon would some day give the world the advantage of his unrivalled learning: in the meantime the author has endeavoured to condense into the present treatise as much of the information to be gathered from these authorities and from his own observations as will be useful to the English amateur, collector, and dealer in old French plate.

W. J. C.

Cirencester,

November, 1892. 


\section{CONTENTS.}

\section{CHAPTER I.}

French weights and measures-The old marc weight-The modern metric system - Table for the conversion of Troy weight into grammes-Table comparing grammes, Troy weight, and marcs -Coin used as weights--French standards for gold-Value of gold of different qualities-Standards for silver-Value of various qualities of silver . . . . . . . . . . . .

\section{CHAPLER II.}

The early goldsmiths of Limoges - St. Martial and St. Eloi-The goldsmiths' guild in Paris-Ancient code for their government -Ordinances of Philippe le Hardi and Philippe le Bel-Letters of confirmation of King John-The craft in the Provinces-The goldsmiths of Montpellier-The Ordinance of 1506-Introduction of date-letters-The Renaissance of Art-List of goldsmiths of the sixteenth century-The school of the Louvre-Destruction of plate under Louis XIV.-Imposition of the droit de marque -The goldsmiths of the seventeenth century - The plate of the Regency-The Rococo period-The classical style-Summary of the marks on old Paris plate, with facsimiles-Table of the Paris date-letters-Table of the marks of the Farmers-General of the duty-Alphabetical list of goldsmiths of the eighteenth century .

\section{CHAPTER III.}

Ancient provincial hall-marks-The Mint letters of provincial centres - The marks of 1783-The standards of Burgundy and Lorraine - Table of arms of towns where plate was made before 1783Table of the marks used under the administration of Jn. Bte. Fouache, 177t-1780-Table of the town marks used from 17831789 
viii

CONTENTS.

CHAPTER IV.

The modern hall-marks of $1797,1809,1819$, and 1838, with tables $\quad{ }^{\text {PAGE }}$

APPENDIX.

Examples of old French plate with makers' names and marks . 99

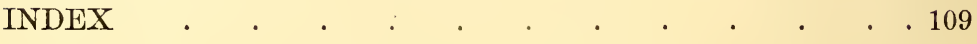


A

\section{HANDBOOK FOR THE COLLECTOR}

\section{oF \\ OLD FRENCH PLATE.}

\section{CHAPTER I.}

FRENCH WEIGHTS AND STANDARDS.

French weights and measures - The old marc weight-The modern metric system - Table for the conversion of Troy weight into grammes-Table comparing grammes, Troy weight, and marcsCoin used as weights-French standards for gold-Value of gold of different qualities-Standards for silver-Value of French standard silver.

IN the Statutes of the Goldsmiths of Paris it is prescribed that the aspirant for reception into the Guild as "Maître et Marchand" must be examined by the six wardens in the divisions of the marc weight, the prices and qualities of gold and silver wares, and the mode of alloying base and fine metal so as to raise or reduce it to the proper standards for working according to the various ordinances of the craft.

If some of this learning would be profitless to the amateur, the divisions of the marc weight still have an interest from an antiquarian point of view ; and a comparison of these old weights with the more modern French, and the Troy weights (which are still used in 
England) will be found of use by the purchaser of old French plate.

Enough has been said elsewhere about the alloys of gold and silver and the methods of assaying those metals, but a few preliminary remarks upon the French standards for coin and plate, seem as necessary as some knowledge of French weights. Taking then the above statute for our text, let us devote a page or two first to weights, and then to standards.

\section{TABLE OF OLD FRENCH MARC WEIGHTS.}

$$
\begin{aligned}
& 1 \text { Marc }=8 \text { ounces }=64 \text { gros }=192 \text { deniers }=4608 \text { grains } . \\
& 1 \text { ounce }=8 \text { gros }=24 \text { deniers }=576 \text { grains. } \\
& 1 \text { gros }=3 \text { deniers }=72 \text { grains. } \\
& 1 \text { denier }=24 \text { grains. }
\end{aligned}
$$

In the old French royal accounts and inventories of the fifteenth and subsequent centuries, the weight of gold and silver plate is usually given in marcs, ounces, and gros or deniers. In the thirteenth and fourteenth century the ounce was as often divided into 20 esterlins.

1360-68. Sis cuillers dor, de plaine euvre, toutes pareilles, sanz différence, pesans 1 marc 11 onces xxd.-Inventaire du Duc d'Anjou.

1380. Un hanap d'or, plain, à couvercle, de la façon d'un calice et a un fruitelet d'une roze, pesant ij marcs vi onces $\mathrm{v}$ esterlins.Inventaire de Charles $V$.

1453. Une couppe d'argent dorée dedens et dehors, poinssonné dessus à ung compaignon et une damoiselle, pesant deux marcs trois onces ung gros.-Acte de vente des biens de Jacques Cour.

1506. Quatre tranchoirs d'or dont en y a deux ronds et deux carrés, pesans ensemble $\mathrm{x}$ marcs iij onces vii gros.-Inventaire de la royne Anne de Bretagne.

The mare weight was abolished at the Revolution, and in 1795 its use was prohibited. The new gramme weights of the Metric System, which was then substituted for it, are used throughout in the law of 19 Brumaire, Year VI. (1797); but the equivalents of the gramme weights, according to the old computation, were 
added in brackets, the public being as yet unfamiliar with the new mode of reckoning.

WEIGHTS OF THE METRIC SYSTEM.

1 kilogramme $=10$ hectogrammes $=100$ décagrammes $=1,000$ grammes $=10,000$ décigrammes.

1 hectogramme $=10$ décagrammes $=100$ grammes $=1,000$ décigrammes.

1 décagramme $=10$ grammes $=100$ décigrammes.

1 gramme $=10$ décigrammes.

It will be seen by the following tables of comparison that the gramme is equivalent to about 19 of the old French grains, or about 15 grains of Troy weight.

TABLE FOR THE CONVERSION OF TROY WEIGHT INTO GRAMMES.

\begin{tabular}{|c|c|c|c|c|c|}
\hline Troy. & & Grammes. & & oy. & Grammes. \\
\hline 1 dwt. & & $=1.555$ & & oz. & $=155 \cdot 517$ \\
\hline 5 ,, & ( $\frac{1}{4}$ oz.) & $7 \cdot 775$ & 6 & , & $=1 S 6 \cdot 621$ \\
\hline 10 ,, & ( $\frac{1}{2}$ oz.) & $=15 \cdot 551$ & 7 & , , & $=217 \cdot 724$ \\
\hline 15 & $\left(\frac{3}{4}\right.$ oz. $)$ & $=23 \cdot 327$ & 8 & , & $=248 \cdot 828$ \\
\hline 20 , & $(1 \mathrm{oz})$. & $=31 \cdot 103$ & 9 & , , & $=279 \cdot 931$ \\
\hline $2 \mathrm{oz}$ & & $=62 \cdot 207$ & 10 & , & $=311 \cdot 035$ \\
\hline 3 , & & $=93 \cdot 310$ & 11 & , & $=342 \cdot 138$ \\
\hline 4, & & $=124 \cdot 414$ & 12 &,,$\quad$ (1 llb.) & $=373 \cdot 242$ \\
\hline
\end{tabular}

COMPARATIVE TABLE OF GRAMMES, TROY WEIGITT, AND MARCS.

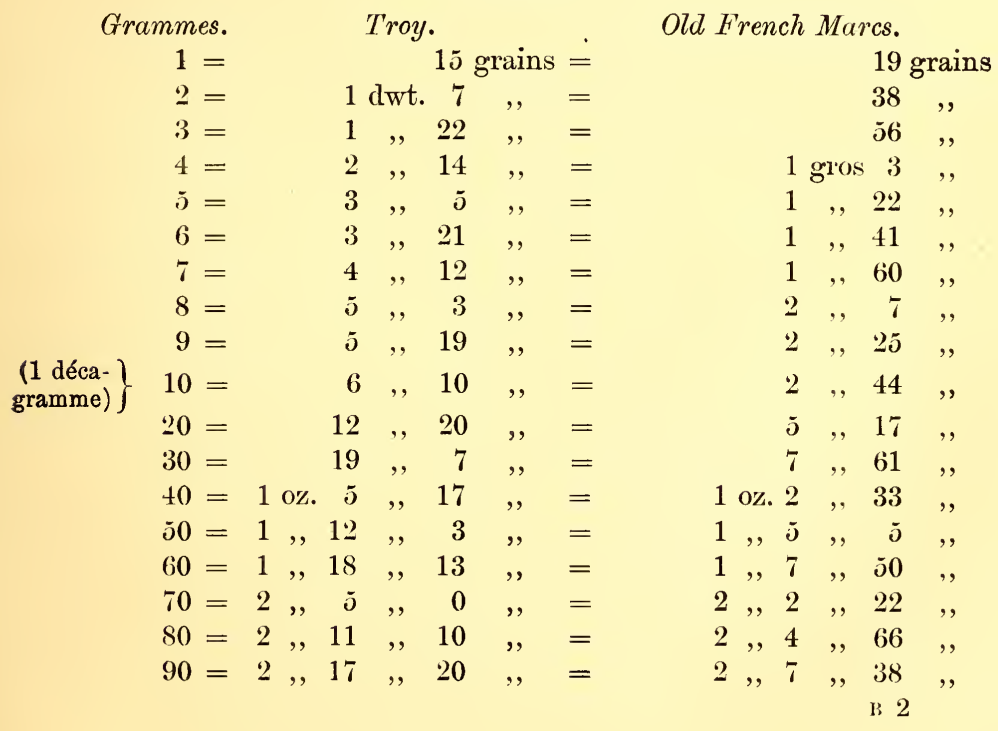


COMPARATIVE TABLE OF GRAMMES, ETC.-continued.

Grammes. Troy. Old French Marcs.

$\left.\begin{array}{l}\text { (1 hecto- } \\ \text { gramme) }\end{array}\right\} 100=3$ oz. 4 dwt. 7 grains $=\quad 3$ oz. 2 gros 11 grains

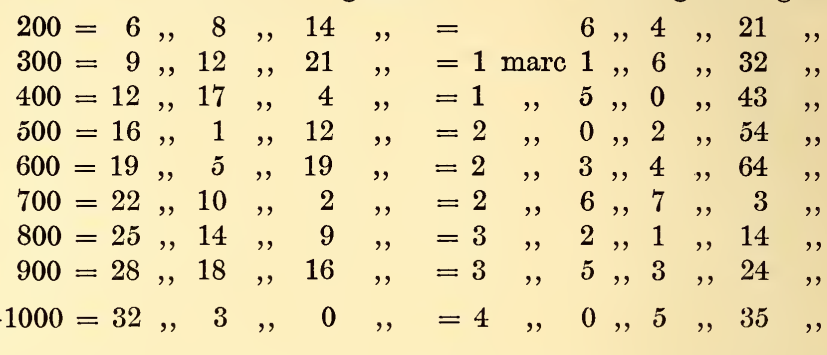

It may be added that the French silver franc piece weighs 5 grammes, the 2 -franc piece 10 grammes, and the 5 -franc piece 25 grammes. The bronze 5-centime piece weighs 5 grammes, and the 10 -centime piece 10 grammes. Unworn French coin of such descriptions can, therefore, be used as weights on emergency at these rates.

\section{FRENCH (PARIS) STANDARDS.}

GoLD.-Gold is divided into 24 carats, and the carat into 32 grains.

The old French standard for gold plate was 191 carats, which was called gold "of the touch of Paris," or or de touche. This standard is mentioned in the thirteenth, fourteenth, and fifteenth centuries.

In 1554 the standard was raised to 22 carats, with a remedy of a quarter of a carat or 8 grains. It may be mentioned that from 1578,22 -carat gold, or, given in millièmes, gold of millesimal fineness 916.66 , has been the English standard for plate, and from the year 1660 for coin also.

In 1721 a second quality of gold was allowed to be used for small wares; this was $20 \frac{1}{4}$ carats fine, with a remedy of a quarter of a carat. 
In 1797 these two standards were abolished by the law so well known as that of 19 Brumaire, Year VI., and the following new ones adopted, which have remained the French standards to the present day:

$$
\begin{aligned}
& \text { 1st standard }=\cdot 920 \text {, or } 22 \frac{5}{65} \text { carats, fine. } \\
& \text { 2nd , }=\cdot 840 \text {, or } 20 \frac{1}{6} \frac{1}{4} \text { carats, fine. } \\
& \text { 3rd }, \quad=\cdot 750, \text { or } 18 \text { carats, fine. }
\end{aligned}
$$

A remedy of 3 millièmes is allowed in the case of all these three standards.

In England a second standard of 18 carats was first allowed in 1798, or about the same time as in France.

The French standard for gold coin is 900 , or in French carat measure, 21 carats 19 grains (English 21 carats $2 \frac{3}{8}$ grains) fine; and its value per Troy ounce would be $£ 316 s$. $5 \frac{1}{4} d$., at the English Mint price of 22-carat gold, which is £3 17 s. $10 \frac{1}{2} \mathrm{~d}$. per ounce. This would be, in grammes and French money, 3.0718 francs per gramme.

At the same rate the following intrinsic values per gramme may be given for the three other qualities of French gold that have been mentioned above, viz. :

$$
\begin{aligned}
& \cdot 920=3 \cdot 137 \text { francs per gramme. } \\
& \cdot 840=2 \cdot 867 \quad, \quad, \quad, \\
& \cdot 750=2 \cdot 561 \quad,, \quad,
\end{aligned}
$$

Fine gold is worth $3 \cdot 414$ francs per gramme.

Silver. - The fineness of silver was measured in deniers, oboles and grains: the unit or ounce being divided into 12 deniers, and each denier into 2 oboles or 24 grains.

The earliest recognized standard was that of the English sterling, of 11 deniers $2 \frac{2}{5}$ grains fine, or in millièmes 925 . This was the standard in 1260 , and no 
other is mentioned till 1355, when argent-le-roy is heard of for the first time. The argent-le-roy was 11 deniers 12 grains fine without the solder, for which a remedy of 3 grains in the case of large wares (grosserie), and 5 for small articles (menuierie), was allowed from 1378. It will be observed that this is of the same quality as the English higher standard silver used since 1697, and would be in millièmes 959 fine.

The remedy was reduced to a uniform one for all wares of 2 grains in 1554, and except for this small change, the argent-le-roy of 1355 remained the standard until 1797, when the law of 19 Brumaire, Year VI. set up the two present standards in place of it. These are:

$$
\begin{aligned}
& \text { 1st standard }=\cdot 950, \text { or } 11 \text { deniers } 9 \frac{7}{10} \text { grains, fine. } \\
& \text { 2nd },, \quad=\cdot 800, \text { or } 9 \text { deniers } 14 \frac{1}{8} \text { grains, fine. }
\end{aligned}
$$

The remedy allowed is 5 millièmes for either quality.

Modern French silver coin, like the gold coinage, is .900 fine, or $4 \cdot 5$ silver to 5 of alloy. This is not so good as the silver of which old French plate was made, nor even as the first quality of modern silver plate, but it is much better than the lower of the two modern standards introduced in 1797.

It must always be remembered that silver francs, like English silver coins, pass current for more than their intrinsic value as metal; a hectogramme of coinage standard silver being coined in France into 20 franc pieces, whilst its intrinsic value as metal is but little more than 13 francs, at the present low price of standard silver, say $3 s .3 d$. English per ounce. 


\section{CHAPTER II.}

THE GOLDSMITHS OF FRANCE, AND THE MARKS USED IN PARIS TILL 1789.

The early goldsmiths of Limoges-St. Martial and St. Eloi-The goldsmiths' guild in Paris-Ancient code for their government-Ordinances of Philippe le Hardi and Philippe le Bel-Letters of confirmation of King John-The craft in the Provinces-The goldsmiths of Montpellier-the Ordinance of 1506-Introduction of date-lettersThe Renaissance of Art-List of goldsmiths of the sixteenth century -The school of the Louvre-Destruction of plate under Louis XIV. -Imposition of the droit de marque-The goldsmiths of the seventeenth century-The plate of the Regency-The Rococo period-The classical style-Summary of the marks on old Paris plate-Table of the Paris date-letters-Table of the marks of the Farmers-General of the duty-The goldsmiths of the eighteenth century.

Acthough the regular records of the Confrérie de St. Eloi, as the most ancient of the guilds of goldsmiths in Paris was wont to style itself, do not commence before the middle of the thirteenth century, but little earlier in fact than those of their brethren in London, nowhere do we find such distinct notices of the art of working in the precious metals during the Middle Ages, as in France.

And if France was the nursery of the goldsmith's art in mediæval Europe, Limoges was its cradle. St. Martial, Bishop of Limoges, was known as the patron of the goldsmiths long before the canonization of St. Eloi. It was hard by, at Solignac, that early in the seventh century St. Eloi, who was destined, as it proved, to supersede St. Martial in popularity with the craft, 
founded an abbey, the monks of which, under his skilful direction, devoted themselves to working in gold and silver, and formed a school, whose members went abroad to spread the fame of their founder, and to encourage the art in other cities. Amongst those which profited most by this instruction were Metz, Paris, and Lyons, whose goldsmiths in their turn, and no long time after, rivalled the craftsmen of Limoges itself.

Some few specimens of the work of this period, one at least attributed to St. Eloi's own hand, remain to the present time to attest the skill of these mediæval artists. The Bibliothèque Nationale at Paris can show the chair of Dagobert, whilst the Imperial Treasury of Vienna can boast of the crown and sword of Charlemagne himself.

In the eleventh century French work other than ecclesiastical or royal comes into notice for the first time. John de Garlandia, writing at the end of it, mentions as a separate class of craftsmen the goldsmiths who held leurs fourneaux et leurs tables sur le, Grand Pont, and made hanaps, buckles, necklaces, pins, and clasps in gold and silver, besides rings set with turquioise, ruby, sapphires, and emeralds. He describes, too, their mode of working as if it were some novelty :-Le métier de ces orfèvres consiste a battre avec de petits marteaux sur l'enclume, des lames d'or et d'argent et à enchâsser les pierres précieuses dans les chatons des bagues à l'usage des barons et des nobles dames.

Here, then, we have the first mention of the goldsmiths of Paris already in their famous quarter on the Grand Pont, which was better known, perhaps, in its connection with their name as the Pont-au-Change, and was occupied by them until it was shaken down once, if not twice, in the course of the thirteenth century, so it is said, by the vibration caused by their hammers. 
St. Eloi had by this time quite superseded St. Martial as their patron, at least in Paris ; his festival day was kept by the craft with great pomp on the 1st of December in each year, and their processional hymus commemorated not only his saintly skill, but even a miracle wrought by him or for him, a conclusive mark of the divine favour.

"Dum vas regi Clothario

Ex auri massâ fabricat

Aurum in fabri studio

Summus Faber multiplicat."

Still there are but few remains of the cunning work of these ancient guilds. Here and there a chasse or reliquary of the eleventh or twelfth century is about all that can be found either in the treasuries of cathedrals or monasteries, or in the Louvre, Cluny, and other such collections.

There is better evidence of the frauds of which they were too often, as it would appear, guilty alike in England and France. Not only are they already open to the charge of substituting inferior for good gold, but of gilding and silvering laten and pewter, and selling it for standard gold or silver, and also of counterfeiting precious stones.

We have incidentally referred, when upon the subject of English plate, to the well-known code of statutes for the regulation of the trade guilds of Paris, that was compiled under these circumstances by direction of Etienne Boileau, the provost of the city, in 1260.

It is obvious that no trade would require more careful supervision than that of the goldsmiths, and here it will be necessary to notice a little more in detail the portion of the code which relates to this craft, for it is practically the first definite date we come to in the history of 
the Confrérie de St. Eloi. It is a mistake, however, to consider this event to mark the foundation of the guild. In point of fact, the goldsmiths' was only one of several trades that owed a sort of codification of their existing traditions to the opportune intervention of the provost of Paris, probably a result of the general move that seems to have taken place in such matters in the thirteenth century. Its regulations (which stand eleventh in the provost's Livre des Métiers) seem to have been compiled from the voluntary depositions of the sworn masters of the craft as to their ancient usages and customs, taken at the Chatelet, where they were summoned for the purpose. It was no new code, though possibly it had never before been reduced to writing. Be this as it may, some of its clauses are of the greatest interest and importance, and such of them must be given in their own quaint words :-

"Il est ì Paris orfèvres qui veut et qui faire le set pour qu'il oevre ad us et as coustumes du mestier qui tex sunt :

"Nus orfèvres ne puet ouvrer d'or à Paris qu'il ne soit à la touche de Paris ou mieudres laquele touche passe tous les ors de quoi on oevre en nule terre.

"Nus orfèvre ne puet ouvrer à Paris d'argent que il ne soit aussi bon comme estelins ou mieudres."

A later clause provides for the good government of the craft in these terms :-

"Et est à savoir que li preudome du mestier eslisent ii preudeshomes ou iii pour garder le mestier liquel preudhome jurent que ils garderont le mestier bien et loiaument as us et as coustumes devants diz et quand cil preudome ont finé leur service li communs du mestier ne les pueent mès remetre à garder le mestier devant iii ans se il n'i voleent entrer de leur bone volenté."

The other provisions forbid taking more than a single apprentice unless he be of the family of the master or of his wife, and forbid taking any apprentice at all for 
less than ten years or for less than 100 sols and his keep (nouriture) ; they also forbid working at night unless it be for the King, Queen, their children or brothers, or the Bishop of Paris; they place it upon record that the goldsmith pays no taxes in regard of his craft ; they prescribe the closing of the forges on feast days, with certain exceptions, when the gains are to be devoted to an annual dinner to the poor in the Hôtel Dieu at Paris; they exempt the craft from "watch" (guet), but not from other dues to the King; and lastly, they enable the ancients to bring any who work bad gold or silver before the provost of Paris, who shall punish them with banishment for four or six years, according to their deserts.

From this time the craft seems to have had a separate existence, with wardens and a common seal; we should expect, therefore, soon to find it the subject of royal ordinances. And we have no long time to wait, for some fifteen years afterwards, in 1275, Philippe le Hardi obliges all. silversmiths working in fine silver to mark their work with the mark (seign) of the town they dwell in, under pain of forfeiture, saying nothing, however, at this time about gold. This omission was remedied by a General Ordinance of the month of June, 1313, in which Philippe le Bel enjoins the marking of gold as well as silver, and, more important still, entrusts the care of the town mark (poinçon) to two prud'hommes, to be elected in each town for that purpose.

"Voulons et ordonnons qu'en chaque ville où il y aura orfèvre, ait un seing propre à seigner les ouvrages qui y seront faits et sera gardé par deux prud-hommes establis et esleus à ce faire: et que un seing ne ressemble à l'autre et qui sera trouvé faisant le contraire il perdra l'argent et sera puni de corps et d'avoir."

Here we come to the establishment of the town mark, 
or poinçon de maison commune. We have already found from the English royal accounts of 1300 that the Paris mark was the flos glegelli, or fleur-de-lis, and we know that the standard of gold it denoted was good enough to command its adoption in that year as the authorised English standard also for gold wares. It was in 1330 that the Paris goldsmiths could boast of a grant of armorial bearings, the very seal of respectability in that age.

It is highly probable that the craftsmen had even earlier than this been in the habit of marking their work each with his own private and peculiar mark; but there is no positive mention of this custom, if custom it were, as yet.

In Paris, the number of the gardes, or wardens, who had charge of the punch, was quickly raised to six, and from 1337 their names are handed down in an unbroken series lasting into the eighteenth century.

No doubt the stringent regulations of a sumptuary kind which were prompted by the necessities of Philippe le Bel, seriously affected the prosperity of the craft.M. Lacroix states that the number of the craftsmen became reduced as well as the size of the articles they were permitted to make.-The goldsmiths, however, seem to have been in a position to demand, or deserve, in 1355, a renewal of their old privileges. The Letters of Confirmation obtained from King John, form the second great landmark in their history, counting the code of Etienne Boileau as the first. They were given at St. Ouen in the month of August, 1355, and contain, amongst others, the following items important for our present purpose.*

* Collection de pièces relatives à l'histoire de France, par C. Leber, Paris, 1838. Vol. XIX. 348. 
"Premièrement. Il est à Paris orfèvre qui veut et qui faire le sect pourtant (pourvu) quil ait ésté aprentis à orfèvre à Paris ou ailleurs aus us et coustumes du mestier ou quil soit tel esprouvé par les maistres et bonnes gens du mestier estre souffisant d'estre orfèvre et de tenir et lever forge et d'avoir poinçon à contreseign.

“2. Item. Si celuy éprouvé est tel qu'il doive estre orfèvre et avoir poinçon et il a été ouvrier d'autres metaux autres que d'or ne d'argent et il veut etre orfèvre et il le sera mais il n'ouvrera ne fera ouvrer jamais d'autre metal que de bon or et de bon argent, si ce n'est en joyaux d'Eglise commes Tombes, Chasses, Croix, Encensiers ou autre joyaux accoutumez à faire servir Sainte Eglise ou se ce n'est du congié et licence des maistres du mestier et jurra à tenir (forge) et ouvrer aux us et coustumes du mestier qui telles sont.

“3. Nul orfèvre ne peut ouvrer d'or à Paris qu'il ne soit à la touche de Paris ou meilleur la quelle touche passe tous les ors dont l'on euvre en mille terres, lequel est à dix neuf carats et un quint.

“12. Nul orfèvre ne peut ouvrer d'argent qui ne se revienne aussi bon comme Argent-le-Roy sans les soudures lequel est dit argent de gros."

Twenty-five other clauses repeat all the regulations collected and recorded in 1260 , but in far more minute detail, and provide for the annual election of six wardens, "pour le garde de l'orfèvrerie," with power to reprimand offenders, or at a third offence of bringing them before the provost of Paris.

This charter is noteworthy for several reasons. It illustrates the course of legislation in England, and forms an important point in the history of French marks and standards. In the first place, it definitely mentions a maker's mark for the first time, and not only so, but describes it as a punch with a countersign. This countersign has been explained to be some small emblem, such as a heart or other figure of that kind, to be added to the initials of the maker's name for the purpose of distinguishing it more specifically from that of any other maker. In later French this small addition would be called devise. 
It will be observed, too, that the quality of gold of the touch of Paris is defined as gold $19 \frac{1}{5}$ carats fine. Laborde quotes an entry from the accounts of the Duke of Burgundy of the year 142:3, three-quarters of a century later than this, in which "or de touche" is still "xix karas et un quint," and a standard below which one dare not work. It held its own until the middle of the sixteenth century.

Thirdly, the charter brings us to the afterwards familiar "argent-le-roy," the quality of which, we may remark in passing, is the same as our English higher, or Britannia, standard silver. This was 11 deniers 12 grains fine, and containing therefore, only one twentyfourth part of alloy, it must be admitted to have deserved its name.

In 1378, we come upon the first allowance of a remedy or margin from the actual standard, if within which, the metal should be considered as of standard quality.

In that year, Charles V., supplementing the Ordinance of 1355 in this and other respects, at the request of the wardens of the craft, prescribes that the silver used should be "argent qui soit aussi bien et se revienne sans les soudures comme l'argent appelé l'argent le roi lequel est a onze deniers douze grains fins, et auront remède de trois grains au marc d'argent et surplus." This remedy is specified to be for large works, and a remedy of five grains and no more is to be allowed for smaller wares. It permits no such tolerance in the case of gold.

All this time the art was flourishing in various provincial towns and cities of France, no less than in Paris : in fact, the trade must have been in full work everywhere, to judge by the inventories of plate and jewels of the Dukes of Burgundy ; of Louis, Duke of Anjou, which was 
drawn up about the middle of the fourteenth century; and the other royal and ducal accounts of the same period. All of these are full of information and interest for the historian and antiquary.

Letters conveying similar privileges to those already granted to the goldsmiths of Paris, were, no long time afterwards, obtained from the same sovereign by their brethren of Puy-en-Velay (in 1367), and by Troyes (in 1369); to which must be added Tours and Bordeaux about a generation later. Limoges and Montpellier, too, maintained their ancient reputation. Of most of these cities mention is made in the inventories above referred to; and besides Paris, Avignon, Limoges and Montpellier could boast of styles and standards of their own, which were well enough known to command special entry and notice. Possibly these local standards were not very high ones : 14 carats, or afterwards 16 carats, was the gold standard of Puy-en-Velay in this century, and that of Montpellier seems to have been no higher than 14. As early as 1260 there is a warning recorded against using Montpellier gold; and its silver was not first-rate, containing but a third part of alloy, and being thought good enough if it came out of the fire white. This quality was actually called "argent de Montpellier." The curious accounts of the goldsmiths of this city which have been collected by local archæologists* throw much light upon our subject generally. We find from them that the mode of assay as now practised was in use in the fourteenth century, and that the workers in gold and silver there constituted a regular fraternity, governed by statutes in which the above Montpellier standards

* Publications de la Société Archéologique de Montpellier, No. 14. Title Argentiers. 
were prescribed, and by which the goldsmiths were expressly forbidden to manufacture articles in gilt or silvered copper or brass, save ornaments and utensils for churches, to mount real stones in jewellery of base metal or to set false stones in silver or gold.

It appears that by 1355 great abuses had grown up in the fabrication of articles of silver, and the result of the consequent disputes between the consuls of the town and the goldsmiths was that the following regulations for the trade of goldsmiths were made :-

All vessels and works of silver made by the silversmiths (argentiers) of Montpellier were to be of the standard of 11 deniers and 1 obole, or 12 grains, at the least. They were to make two patterns, or trial pieces, of silver of the standard of 11 deniers 14 grains, marked with the punch of Montpellier, after which they should work with an allowance or remedy of 2 grains. One of these trial plates was to be kept at the Consulate, and the other by the warden of the goldsmiths. A third trial plate was to be made 11 deniers 1 obole fine, and similarly marked, which was to remain with the consuls for the trial of suspected works. Every master was to mark with his own particular mark the pieces of his work, and to deliver them himself to the warden, who before marking them with the poinçon of Montpellier was to remove a portion of the silver, called the borihl, which he was to put into a box, keeping a separate box for each workman. Once or twice a year he was to make an assay of these borihls, and if the standard was found below the 11 deniers 1 obole, he was to summon the worker before the consuls, who should make a second assay, and if they found the fraud confirmed, should deliver him over to justice. The wardens were to break such articles as seemed to them insufficient. It is ordered, 
moreover, that in assaying the trial pieces and the borihls, the same ashes, lead and fire should be used; so it is clear that the assay was by the cupel. Nothing had hitherto been said or done about gold; but though less worked than silver, there were equal abuses; and in 1401 the consuls and wardens of the mystery, assisted by several argentiers, made a regulation in presence of the consuls of the city by which the standard of gold, which had been originally only 14 carats, but had by a subsequent decree been raised to 18 carats, was now reduced to 16 , and there is a question about the trial of gold by the "touch," showing that it was then in use.

All this may serve to show that the regulations under which the goldsmiths of Paris worked and the privileges they obtained, were much the same as those which ordered and dignified the craft all over France. Each city had its mark, and its makers each their poinçon $\dot{d}$ contreseign. It may also be inferred from the inventories of the century that the prosperity of the goldsmiths was not, at this time, seriously affected by the sumptuary laws of which so much is heard both earlier and later on. Other troubles indeed they had late in the century, for the domestic dissensions of the reign of Charles VI. must have gone far to drive such a craft as theirs out of the country for security. Although neither its work nor the course of its records was actually broken, there is plenty of evidence that the goldsmiths of Flanders were largely profiting at the cost of France. And these troubles ended not with the century. The English invasions of the next must have been simply ruin to the trade. The goldsmiths of Bruges, Brussels, Gand, or Dijon, rather than those of France, had name of note all through the reigns of Charles VII. and Louis XI., whilst craftsmen of Tours, Blois, Rouen, and 
Boulogne are mentioned more often than those of the capital. It would be difficult to pick out more than a dozen names to represent Paris, or even France, for the whole of the fifteenth century, and more difficult still to find any specimens of their work. Herman Roussel was goldsmith to Charles VI., and Hans Croist was of the household of the Duke of Orleans, in the double capacity of goldsmith and "varlet-de-chambre." Gilhert Jehan of Tours is known as the goldsmith of Charles VII. ; Jehan Gallant of Charles VIII. ; and to these may be added the names of Haliévre, Fernicle, and Barbier, goldsmiths in ordinary to Louis XI. It may be doubted whether these were all Frenchmen. Amongst the provincial craftsmen were André Mangot, Guillaume Poissonier, and Conrad of Cologne, all dwelling at Tours, Michel Blondel at Blois, Jehan Martin at Boulogne; and their names seem of as much consequence in the inventories as if they had been citizens of Paris itself.

Foreign wares of base alloy and without any marks at all were at this time sold, says Lacroix, by itinerant dealers all over the country, and it was not until the very end of the fifteenth century or the beginning of the next, that law and order in these matters began to reassert themselves.

Signs of reviving prosperity may however be observed about 1470 in the provisions contained in the royal letters to the goldsmiths of Tours in that year, directing that nothing hut reliquaries should be made of base metal; and also in the increasing stringency towards the end of the century of the ordinances enjoining on the officers of the Mint the more careful surveillance of the goldsmiths and their work.

In 1506 comes what we may call a third great point 
in the history of the guild of Paris. By the Ordinance of Blois, given in the month of November in that year, all the goldsmiths were ordered to make themselves new punches, and the sworn masters of the craft were directed to mark all plate with a counter-mark, to be changed every year, registered at the Mint, and stamped upon a copper plate beside the name of the wardens to whom the punch belonged.

Here at last we have distinct mention of what must be the Annual Letter that is always for the future to be found upon Paris plate, at least until 1783.

But, as in England so in France, it is clear that such a letter had been already long in use; and just as the London letter can be traced to 1478, although it is never formally mentioned till 1507 , so in Paris an annual letter had certainly been used since 1461 .

It is known that a new alphabet began with the letter A on Feb. 5, 1506-7, followed by B on Dec. 10 in the same year 1507, the last-mentioned day being the time of the new wardens' election.

An earlier alphabet, of which the letter $M$ stood for 1472, is referred to by Pierre de Rosnel in the Third Part of his Mercure Indien, published in 1667. To this the A of 1506-7 is in proper sequence, 23 letters being always the length of the Paris alphabet; and in the other direction a letter $\mathrm{M}$ for 1472 will take us back to 1461 for the commencement of an alphabet half a century older than that of 1506 .

It is a curious coincidence, if nothing more, that another cycle of 23 letters would bring us to the year 1431, allowance being made for some irregularity in the election of successive wardens, or within three years of the date at which a date-letter was first used at Montpellier. Each letter, as a rule, represents a set of 
wardens, whether their period of office endured more or less than a year.

If we turn again to the records of Montpellier we shall see what strong reason there is for crediting that town with the invention of this simple plan of fixing the wardens of each year with their proper responsibilities and of tracing any laches to the proper offenders.

In the fifteenth century abuses and frauds in the trade had greatly multiplied. Public clamour was raised against the principal silversmiths for working below the standard of 1355, and a process was instituted against them in 1427. The consuls seized several of their works, had them assayed, found them fraudulent, and made them appear before the tribunal. In their defence they pleaded that the ordinances of 1355 were obsolete with regard to small orfêvreries. They were condemned to pay a fine of ten mares of silver each, and on appeal the sentence was confirmed. Then they claimed exemption from marking girdles and small works; an inquest was held, and the following ordinances resulted, which were solemnly renewed in 1436 with still stricter conditions. They show with what care the fabrication of works of gold and silver was now regulated. To insure for the future the legal standard, they ordained, besides. the ordinary precaution of the box, the borihls, and the mark of the smith, that the name of the warden of the mystery inscribed on the register of the city and on the private book of the silversmith should be followed by one of the letters of the alphabet, which should be reproduced beneath the shield of arms (écusson) of the town on each work in order that it might be known under what warden it was marked. The minute detail in which this new plan, and the specific reason for its. 
introduction, are here described, gives the transaction all the appearance of being the original invention of the alphabetical mark, and if so the first invention and adoption of this celebrated and now time-honoured mode of marking plate must be attributed to the authorities at Montpellier in 1427. What can be more probable than that the improved security against fraud soon commended itself to the goldsmiths of Paris, and that they too adopted the date-letter in 1431.

Whether it will ever be traced to any earlier period or not, the Paris date-letter appears to have been used with an almost complete regularity from 1461; so much so, that although some few letters have served for rather more and others for rather less than a year, if alphabetical tables of twenty-three letters are used (that is to say, alphabets omitting $\mathrm{I}$ or $\mathrm{J}, \mathrm{U}$ or $\mathrm{V}$, and $\mathrm{W}$ ), any letter will fall within a year or so of that in which it was really used from 1461 to 1783 . The slight irregularities are owing to each letter representing not exactly a year but the term of office of a particular set of wardens.

We must now go back to 1506 and the ordinance of Blois, to which is attached the usual clause forbidding any plate to be made of more than a certain weight, this time the limit being three mares in weight and under, except by authorization of the king. Prohibitions of this kind were fast becoming insupportable, and indeed impossible to enforce now that prosperity was reviving and trade upon the increase. Four years later, in 1510, all restriction was removed, and the goldsmiths might fashion articles of any weight they liked, provided only that they were the proper alloy.

It is at about this time that the goldsmith is said to have added to his private mark the initial letters of his 
Christian name and surname. The maker's mark seems previously to this to have consisted of some device surmounted by a fleur-de-lis or a crown or both, to which had been added about the end of the fifteenth century, it is said in 1493, two small dots or points in allusion to the two grains of tolerance or remedy which they were allowed.

It must, however, be remarked that the remedy was three, or in some cases, five grains from 1378 ; and that nothing is positively known of a remedy of two grains till 1554.

Brighter times are coming with the revival of art, so well known as the Renaissance, that distinguished the sixteenth century. For France it was the century of Francis I. and Henri II., whilst the name of Benvenuto Cellini alone is enough to mark it in the history of art. The restraints of sumptuary legislation are heard of no more. The personal interest taken in the work of the goldsmith by Francis I. was equalled if not surpassed by that of his successor, and Diana of Poitiers, the mistress of the latter, is not unjustly called by Lacroix, the queen of the arts of the Renaissance. It was under Francis I. that we come upon the first of the infringements of the rights of the guild by the Crown that afterwards became more common. However bitterly they may have resented it, they were not able to prevent the establishment by this monarch in $154 \tilde{J}$ of the Hospital of the Trinity, with certain privileges for such of its inmates as were goldsmiths. These privileges, although somewhat abridged from time to time, were still in existence in 1734.

After an abortive and Quixotic attempt in 1540 to raise the standard of gold-work to absolute purity save only for a remedy of a quarter of a carat, or at least to 
establish a standard of twenty-two carats without any remedy at all, which was an equally hopeless project, the very prosperity of the Paris guild, continually on the increase as it was, almost of itself necessitated its reorganisation. It had now remained on the same basis without any reform since 1378. The number as well as the wealth of the craftsmen had increased with that of the population generally, and in 1554 the Edict of Fontainebleau, dated in March of that year, following close upon and superseding one given at Sainte Menehould a few months earlier, did what the abortive attempt of 1540 had failed to effect from trying to do too much. It raised the standard of gold-work for the future to twenty-two carats with a remedy of a quarter of a carat; a similar step to that taken in England by Queen Elizabeth a very few years later, in 1578. The French Edict of 1554 did much more than this, limiting the number of goldsmiths and remedying thereby the abuses which their excessive numbers had rendered it impossible to prevent, resettling the always vexed question of apprenticing, establishing as we have said a gold standard of twenty-two carats with a remedy of a quarter of a carat, and a silver standard of 11 deniers 12 grains with a remedy of 2 grains, under heavy penalties, and regulating the craft in many other particulars, some of which were modified in the following year, but not any of those of chief importance. All the privileges and rights of the guild were solemnly recognized and confirmed by a further set of royal letters in 1572, granted by Charles IX.

The best known names of the century, besides that of Cellini, are Pierre Mangot, goldsmith to Francis I., Étienne Delaulne, born 1520, and François Dujardin, goldsmith to Charles IX. in 1574. We must not, how- 
ever, forget François Briot, who was a goldsmith, though better known for his masterpieces in pewter, which were probably models for execution in more precious metal.

It is impossible to leave this brilliant period without a few more words. Cellini himself testified to the excellent workmanship of the Paris goldsmiths, among whom he found himself on leaving Italy in 1540, and though he worked in Paris but five years before returning to Florence for the rest of his life, his influence was so marked that exception must not be taken to his being reckoned amongst the artists of France for the purposes of this sketch. Few of the works now ascribed to him are so on any authority except their general style and excellence; but a salt-cellar made for Francis I., which he himself counted for a chef-d'cuvre, is preserved at Vienna; and Lasteyrie specially mentions a magnificent ewer of mounted onyx by his hand which, formerly in the Louvre, was since in the collection of the late Mr. A. J. Beresford Hope. Of the other names, no doubt that of Etienne Delaulne stands pre-eminent. The interior of his workshop is given on the cover of the South Kensington Museum Penny Handbook on Gold and Silver, as well as in the treatises of Lacroix and Lasteyrie, after an engraving which is preserved in the Bibliothèque Nationale together with a large number of Delaulne's designs. These designs are all by the artist's own hand, and are on this account of very great artistic value. Ruling the school of French goldsmiths for nearly a quarter of a century, he seems, especially when working farther east at Strasbourg, to have had no less influence with the craftsmen of Augsburg, and possibly of Nuremberg also. The goldsmiths of the end of the century hardly rivalled those of the preceding generation, though 
the names of Vimont and of Jean de la Haye are not unknown.*

The seventeenth century, on entering which we pass from the fashions of the Renaissance to those of more modern art, teem with the names of craftsmen of celebrity. At the very commencement of it we find Henri IV. establishing a royal school of art in the Louvre by letters patent of 1608, lodging there a number of the most skilful painters, sculptors, clockmakers, and others, not forgetting the goldsmiths. Amongst the latter were the brothers Masbraux, natives of Limoges, after whom follow in brilliant succession Réné de la Haye, Pierre Lescot, Alexis Loir, who was one of the first of the goldsmiths lodged by Louis XIV. at Gobelins, Claude Ballin, and his equally celebrated son-in-law Nicholas Delaunay, to whom we must add the name of Pierre Germain, father of a still more distinguished son. The style of decoration a medailles, so popular at the very commencement of the eighteenth century, is attributed by the baron Jérôme Pichon for its invention to Nicholas Delaunay when executing a toilet service for the Duchess of Burgundy. Examples of this style are found in 1703, 1707, 1710, 1719, and 1723.

* Chronological List of some of the best known French Goldsmiths of the Sixteenth Century.

Matthieu Le Vachet, 1480-1512.

Pierre Mangot, c. 1510-1540; goldsmith to Louis XII. and Francis I.

Pirame Triboullet, c. 1529.

Benedict Ramel, c. 1538 .

Claude de la Haye, c. 1550; goldsmith to Charles IX.

Etienne Delaulne, b. 1520.

Benvenuto Cellini, worked in France, 1540-154う.
Claude Marcel, b. 1520.

Richard Routin, temp. Henry II.

Jean Regnard, c. 1570.

Pierre Nicolas, c. 1580.

François Dujardin, c. 1572; goldsmith to Charles IX.

Jean de la Haye, son of Claude; goldsmith to Gabrielle d'Estrées.

David Vimont, goldsmith to Henri IV.' 
Where are the works of these favoured artists, so envied by their brethren for their extraordinary privileges? Alas! it must be said that they are entirely gone, though some at least, including those of the famous Ballin, were preserved, or at all events the memory of them, by the drawings made by Delaunay before they fell one and all under the ban of 1688 . The destruction of plate in England, under William III. in 1697, had been anticipated by a far more thorough holocaust in France, Louis XIV. himself hesitating not to set the royal example by melting up all that had rendered the great fête at Versailles in 1668 famous for all time. It is said that an hundred thousand mares of metal, all in masterpieces of Ballin and the other chief artists of the day, were sacrificed by the Grand Monarque to State necessities. Much of it consisted of silver tables. and such sumptuous furniture as that of the same date and fashion which in England is still preserved at Windsor and Knole to tell of the luxury of the reign of Charles II. With such an example no wonder that each loyal noble and courtier followed suit, nor that so little old French plate can now be found, how diligently soever it be searched for by amateur and collector. The less matters it perhaps that by the Revocation of the Edict of Nantes in 1685 a number of workmen of great merit were lost to a country, which would so soon have sacrificed their choicest productions.

We had almost passed by what is for our purpose one of the most important steps in our record, namely, the imposition of a duty on plate by a declaration of 31 March, 1672. Earlier sovereigns had not overlooked such a means of increasing the revenue; but attempts in this direction made by Henri III. and Louis XIII. had failed, and it was not until the days of Louis XIV. that 
the successful imposition of a droit de marque incidentally supplies the student with a means for the future of dating French plate. Hitherto it had borne the mark of the worker and that of the common hall, which for some two hundred years had been a date-letter. By means of this last mark one would suppose that it was a comparatively easy matter to assign a date to any specimen of plate upon which it appears. This is, however, not the case, or at all events it is a much greater difficulty than in the case of English plate, owing first to the smaller difference that there is between the style of one French alphabet and another, and secondly to there being, in the case of French plate, no such additional marks as the lion passant and leopard's head crowned, which are so great a help for dating old English plate. In point of fact it is not until 1672 that the addition of the mark of the farmer of the duty, enables us to identify with certainty the year signified by any particular alphabetical letter.

The mark of the farmer was to be the Mint letter of the town surmounted by a fleur-de-lis, and a new design for the letter was adopted by each successive tenant of that perhaps lucrative post. From 1672 French plate bears this third mark, called the poinçon de charge, in addition to the other two. For Paris it was the letter A.

A fourth but less important mark was added in 1681, when the farmers obtained the right of marking plate both in its rough state and again when finished; the one mark by way of denoting its liability to the charge, and the second certifying to its due payment or discharge. This fourth mark was called the poinçon de décharge.

From 1681 there are accordingly four Paris marks; and the punches of the charge and discharge used by 
each successive farmer of the duty being of different fashion from those of any of his predecessors in office, enable us to fix the date of any alphabetical letter with which they are found, the names, dates, and marks of each farmer being known. Thus it will be observed by the aid of the tables at the end of this chapter, that the letter $\mathrm{S}$ of 1734 can be as readily distinguished from that of 1711 as from those for 1758 or 1781 ; the letter for 1734 being associated with the punch of the farmergeneral, Hubert Louvet, and the other letters with one or other of the quite different punches affected by his predecessor, Étienne Baligny, or his successors in administration, Eloi Brichard and Henri Clavel. These marks will enable the English amateur to fix the date of specimens of old French plate, at least from 1672; and there is very little older plate left for him to date, owing to the circumstances we have narrated. These punches remained in use until the abolition of all taxes in 1791.

The size of the maker's mark as well as of the dateletter was fixed in 1679 as two lines high by one and a quarter wide, a matter which had hitherto been left to individual discretion.

It is amid the lamentations of writers on French art that we have arrived at the end of the seventeenth century-lamentations on the decay of taste which relegated the task of designing to a school of architects and sculptors who had but one style for everything. "On ne mettait pas de différence," says Lacroix, "entre la décoration monumentale d'un hôtel et celle d'une église ; on ne croyait pas qu'une statue de saint ou d'apôtre devait peu ressembler à celle d'un demi-dieu païen, on manquait de ce sentiment qui fait l'art s'inspire toujours de son but et de son objet." It may be admitted that 
the plate of the days of Louis XIV. was sometimes too gross and massive in style to be actually pleasing, but many good judges have a real admiration, if only half avowed, for the work of the school that was ruled over by Mansard and Lebrun. It has merits of its own, even if it does not appeal to every standard of taste; it is characteristic of its time, and worst styles have had their day.*

Between this and what may be called the Rococo period, there comes the same transitional style in French, that is noticed in the history of English, art. In England there was the plain, perhaps too plain, plate of William III. and Queen Anne, of which gadrooning was almost the only ornament, yielding first to the sort of decoration that is associated with the name of the engraver Hogarth before it is covered with the exquisite chasing, chiefly in flowers, insects, and other natural objects, of the later days of Paul Lamerie the Frenchman, who working in London from 1712 to 1751 made for English silver a celebrated name which it thus owed in reality to France. In France we find the style that has been aptly called the style of the Regency, prevailing from about 1710 to 1735 , and leading up by a. natural step to the period of Louis XV.

* Chronological List of some of the best known French Goldsmiths of the Seventeenth Century.

Réné de la Haye, 1620-1640; goldsmith to Mazarin.

Pijard, c. 1630.

Pierre Lescot.

Jacques Delaunay.

Pierre Baille, c. 1646.

Mellin, 1650-1700.

Claude Ballin, b. 1615, d. 1678 ; goldsmith to Louis XIV.
Alexis Loir, b. 1640, reçu 1669 (Gobelins).

Nicholas Delaunay, son-in-law of Ballin, reçu 1672, d. 1727.

Pierre Germain, $d$. 1684, aged 39.

Pierre Bain, $c .1685, d .1700$ (Louvre).

Montarsy, c. 1690.

Louis Loir, 1692 -1710.

Alexis Loir, son of Alexis, reçu $1689, d .1713$. 
For a time the dire necessity which compelled the sacrifice of every art treasure of intrinsic value in 1688 served also to forbid or delay their being replaced; and with such rigour were the ordinances in that behalf enforced, that the trade of the goldsmith may be almost said to have been in a state of suspended animation until about 1720. The age of copper, says Lacroix, had succeeded to the age of gold and the age of silver.

Nevertheless, some means were found of educating the skilful hands of the younger Ballin, of Thomas Germain, so celebrated for his toilet services,* and of Besnier, names which no long time afterwards compose a group, the mere mention of whose work is enough to send the French connoisseur of their style into a rhapsody. It has been thus happily described by a distinguished French amateur:- "Dans ce style aimable et tout français, si français qu'il n'a guère été imité à l'étranger, on trouve la correction et la grandiose du style de Louis XIV., mais dépouillé de sa raideur. La grâce la plus parfaite, l'esprit le plus ingénieux, le goût le plus riant, viennent se joindre à l'ampleur, à la noblesse, à la solidité des ouvrages du grand siècle. Dans l'orfèvrerie, les artistes travaillant dans ce style ont fort usé du chanlevé, c'est-à-dire, de ces ornements pris sur pièce avec un relief très-doux, mais assez fort pour préparer la voie à ces effets de lumière, qui donnent tant de valeur et de charme à l'ornementation des métaux; cela ne les a pas empêchés d'user du hautrelief, avec une douceur et un fini de ciselure qu'on ne saurait trop louer." And truth to say, this high esteem is not unjustified, for to the eye wearied with the

* He made no less than five services for royal personages between the years 1725 and 1733 . 
ostentatious grandeur and weight of an earlier school, the fine chasing of the new style de la Régence which now came into fashion, and its exquisitely graduated bas-reliefs, with their pleasing effects of light and shade, had an irresistible charm. Curiously enough, the texture of the metal used at this time sometimes strikes one as rather coarse-grained, and even when highly ornamented and chased looks rather like what iron founders cali "fine cast." This is probably due to the alloying metal. It is also of rather a yellow tone of colour, owing to the same cause.

To the goldsmiths of Paris nearly all the finest examples of this period are to be ascribed. The capital was now able to attract and keep the best talent of the craft in its permanent service; and this is not so much the effect of royal patronage or the influence of the schools of the Louvre and Gobelins, as of a centralisation that has never since relaxed its force.

Sumptuary legislation at last entirely gave way before modern enlightenment and the growing luxury of the times, and the year 1721 makes an end of restrictions, at all events as to the use of silver, which would in any case have been out of joint with the days of Madame de Pompadour and the Dubarry.

At the same time a second standard of twenty and a quarter carats, with a remedy of a quarter of a carat, was allowed for gold wares of small size.

Unfettered, then, by antiquated legislation, and fostered by the great ladies of the Court of Louis XV., the full tide of the Rococo period succeeds to the fashions of the Regency. Nicholas Besnier gives place to his son-in-law Roettiers, and the chaste style of Germain to the caprices of the gout de rocailles which were affected even by Ballin. 
Delaunay resigns in 1723 the post of orfèvre du Roy which he had held for forty-two years, and to him succeeded the trio composed of N. Besnier, C. Ballin, and T. Germain, each of them to serve for a year successively-T. Germain in 1725 .

But the real rival of T. Germain was neither of these, but rather Meissonnier, who was succeeded in style by J. Roettiers, just as the school of T. Germain was perpetuated in his pupils, Buron, Lenhendrick, F. T. Germain, and eventually R. J. Auguste.

Grace, purity, and truth, were the characteristics of Germain and his school, while the exuberances of the rococo distinguished the work designed by Meissonnier and his successors.

This rococo style was in fullest vigour for some twenty years only, from 1735 to 1755 ; and then its extravagances sobered down into the flower sprays and ornamental gadrooning which distinguished the same period (1755-1765) in England also. This, which is the period of ordinary Louis XV. taste, as distinguished from the rococo, carries us on to the classical period of Louis XVI. with its delicate hinds' feet, its mantlings and folds of drapery tied up with ribands over medallions, and the other features of this well-known style, so celebrated for its furniture as well as its plate.

A few words about the pieces of plate which afford us examples of the work of the notable periods we have mentioned.

First the ecuelle or low bowl with two flat handles, a cover, and a plate or tray to stand in, was a very favourite piece both in the Regency and the Rococo period. Examples are found from 1720 to 1765 , first in the style de la Régence and later with the most extravagant ornament of the time. 
The aiguière avec sa cuvette, or ewer of jug shape with a handle and cover, standing in a deep dish or basin, was equally fashionable for the same period; and beautiful specimens of such ewers, some with busts on the handles, and bulrushes arising in bunches around the body from water waves, others with canaux tournans rising out of a base of waves, are found from 1720 to 1735 .

Grand terrines and soupières are found from 1730 to 1750 with a heap of dead game, or vegetables, or shellfish on the covers; and a little later than this, say 1760 to 1770 , these inanimate objects are replaced by groups of men and dogs, sporting or military groups. Canaux tournans without water waves are a little later than when they occur, as we have mentioned, with them, say from 1760 to 1770 , and the figures of swans are found upon pieces of the years 1753, 1765, and even as late as 1773 .

But most of these beautiful vessels have disappeared, for as in the last generation, so again in 1759 , much good work was melted up almost as soon as made, the King as before leading in the patriotic sacrifice, followed by the princes of the blood, the Dauphinesse, Madame de Pompadour, Belleisle, and Choiseul.

[From this to the Revolution of 1789 there is only a single step, but before taking it, passing mention must be made of a name that has made itself famous in the annals of the goldsmiths of Paris. It was to Pierre Le Roy, one of their past wardens, that they owed a complete code of the statutes and privileges of their guild, as they were in 1734. It is only less valuable than the old compilation of Etienne Boileau; and it is the more to be lamented that the scope of his researches did not include the ancient marks used by the corporation as well as its ancient privileges, for it is clear that he had access to sources of information that have now 
for ever disappeared. Though it is not a chronological account verified by references, it is nevertheless a complete summary of all that then regulated the craft, arranged in chapters and clauses for the use and guidance of the wardens and craftsmen of the day. For us it may serve to show what of the various regulations we have noticed remained in force in his time.

We gather from it that the government of the guild remained the same as we have given it; that the standards both of gold and silver were unaltered-notice being taken of the then new one of a second quality of gold, introduced under Louis XV. only a few years before; - and that the counter-mark, or poinçon de Paris, was in the same careful keeping as ever.

The number of Paris goldsmiths was still three hundred, as fixed in 1612; but those who dwelt within the privileges of the Hospital of the Trinity, as well as those of the Louvre and Gobelins, and also those who enjoyed arrêts and letters patent, were considered supernumerary to this established limit. All alike were recognised as members of the guild for every other purpose.

The goldsmith's own mark was to be a punch bearing a fleur-de-lis crowned, with his name and device; its size was to be as before, two lines high by one and a quarter wide.

They were to keep in their shops tables of the value of the marc of gold and silver, of the prescribed standards according to which they ought to work, and of the sub-divisions of the marc weight.

There are a few other clauses of interest, amongst them one that shows how carefully the ability and knowledge of aspirants for the honourable position of mastership in the craft was inquired into by the wardens. They were charged to examine such aspirants not only 
in the sub-divisions of the mare weight and the prices and alloys of gold and silver wares, but in the manner of alloying base and fine metal so as to render it of the quality required by the various ordinances. The wardens were also to inform themselves as to the manners and moral conduct of such candidates.

Another good regulation is that which requires the goldsmith to sell the metal of their works separately, as it were, from the fashion, distinguishing in the bills rendered to customers the amount paid for material and for workmanship respectively.

It may here be remarked in passing, that from 1749 foreign plate imported into France was to be marked with a punch representing the letters $\mathrm{E} T$, or else the single letter E.]

Let us now take the last step in our historical sketch. To complete it, there remains but the reign of Louis XVI. and its well-known classical style. The same oval pointed vases, the same hanging wreaths of flowers or folds of drapery, tied up with knots of riband and carried over medallions, which in England are perpetuated in the designs of the artist Flaxman, form the principal features in French art; but the goldsmiths of Paris were distinguished from those of all other countries by the skill which they lavished upon small objects, such as snuff-boxes, bonbonnières, étuis, and the like.

Two members of the family of Ducrollay, P. J. Antoine, J. George, C. B. Șageret, and A. J. M. Vachette, are amongst the best known of this school, which Lasteyrie, in his Histoire de l'Orfèvrerie, considers to have been the single branch of the goldsmith's art which really flourished in the last quarter of the eighteenth century. R. J. Auguste was almost the only great goldsmith of the reign of Louis XVI. 
If nothing else survived, we may the less regret the general shipwreck of 1789 , in which the history of old French plate and its marks comes to a sudden and disastrous end. The time-honoured series of Parisian date-letters had already terminated in 1783 , the first of many coming changes. For the six remaining years up to 1789 , the poinçon de maison commune was the letter $\mathrm{P}$ crowned, and the stamp was to bear, in the hollow between the crown and the letter, the last two figures of the date (e.g., 84 for 1784), or else some small secret and variable device.* Some think that the mark used in 1789 will be found on plate up to 1791, and perhaps till 19 Brumaire, Year VI. (1797). But the famous statute of this last year, being the foundation of the modern system of hall-marking, must be considered in a later chapter.

\section{SUMMARY.}

To sum up; the marks that will be found on plate made in Paris before 1791 are as follows :-

1. The punch of the common hall (poingon de maison commune) from $1275-1791$.

2. The maker's mark (poinçon du maître) from very early times.

3 . The mark of the farmer of the duties (poincon de charge) from 1672-1791.

4. A second duty mark (poinçon de décharge) from 1681-1791.

Of each of these marks a few words in turn.

\section{THE PUNCH OF THE COMMON HALJ.}

This was first appointed by Philippe le Hardi in 1275, and was in early times the fleur-de-lis (flos glegelli). There is reason to think that down almost to the six-

* It certainly bore such small | the fashion of the letter P varying uumerals in some of these years; about every two years. 
teenth century it was borne upon a lozenge, or diamond, shaped stamp.

Some specimens of the fourteenth and fifteenth centuries bear the mark thus.

Afterwards, say from 1461-1733, it was a letter of the alphabet crowned. This was probably at first a letter added to the fleur-de-lis rather than substituted for it.

A beaker at Oriel College, Oxford, seems to be of Paris make in 1462, and it bears for mark the fleur-de-lis on a diamond, the lower part of which is cut off and enlarged into a second but smaller diamondshaped space, containing the Roman capital letter B placed thus $\forall$ across the bottom of the fleur-de-lis.

From about the middle of the seventeenth century the letter seems to have been simply crowned, and so remained till 1783-4. The alphabets appear to consist chiefly of Roman capital letters, some of them enclosed in a plain escutcheon, others merely countersunk on a punch of the shape of the letter. On gold snuff-boxes of the eighteenth century the letter is in italic capitals for the most part.

In 1784 the letter $\mathrm{P}$ crowned was substituted for the alphabetical letter as the Paris mark, the punch bearing the last two figures of the date (e.g., 84 for 1784) between the crown and the letter, the shape of which letter perhaps varied each year. Certainly three forms of the letter are known : one in 1784, a second appears in 1787 and 1788, and a third in 1788 and 1789.

This new system of marking only lasted till 1789 , though some think that the mark for 1789 did duty till 1791, if not until Nov. 1797 (Brumaire, an VI.). 


\section{THE MAKER'S MARK.}

This was no doubt used long before it is actually mentioned or prescribed by any statute.

In the fourteenth century it was a punch with a counter-sign, which consisted of some small emblem or device (called by Baron J. Pichon différent), with a fleur-de-lis or a crown or both.

To this was afterwards added, it is said in 1493, the two small points or dots which are commonly observed in the marks of French goldsmiths.

By 1506 the maker had added the initials of his name; some had perhaps used their initials as part of their mark long before. In 1679 the size of the maker's mark was fixed by statute at two lines high by one line and a quarter wide.

The goldsmiths who followed the Court, and those who were lodged at Gobelins, early in the eighteenth century, do not seem to have marked their work. Baron J. Pichon notes that the wares of those who belonged to the Hospital of the Trinity have a triangle in the maker's mark to distinguish them.

\section{THE MARKS OF THE FARMER OF THE DUTY.}

The first mark adopted on the imposition of a plate duty in 1672 was the Mint-letter of the Town under a fleur-de-lis. This was called the poinçon de charge, and for Paris it was the letter A.

In 1681 the farmers obtained permission to have plate stamped when finished as well as in the rough, by way of better security for the collection of the tax. The second mark, invented for that purpose, and called the poinçon de décharge, was a small one, usually a human head or that of some beast or bird. It was often not 
placed with the other marks, but will be found on the rim or edge of the article. The first mark would now admit the liability of the article receiving it to pay duty, and the second would acknowledge its due payment. These two marks lasted till the abolition of all taxes in 1791, and a list of them in their successive variations is given next after the tables of Paris date-letters appended to this chapter.

It should be remarked that from 1768 there was a special poinçon de décharge for objects that were marked gratis. This was a royal crown, and it would be applied, instead of any other mark de décharge, on articles made for such personages, royal or official, as might be exempt from liability to the duty.

\section{EXAMPLES OF PARIS MARKS.}
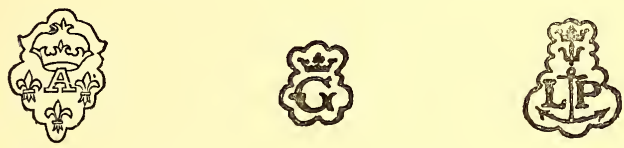

From a small bowl of $1675-6$, probably by Louis Pluviers, with the mark of the 'fermier,' Vincent Fortier.
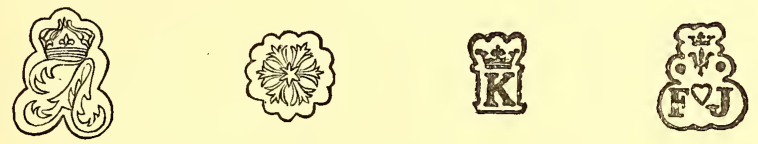

From an aiguière of 1773-4 by François Joubert, with the mark of the 'fermier,' Julien Alaterre, and the poincon de décharge.
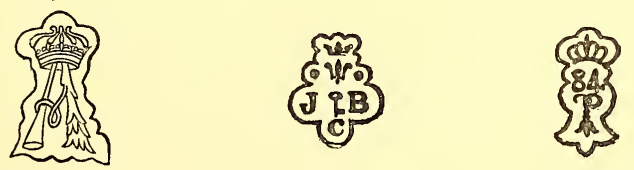

From toilet boxes of 1784 by J. B. Cheret, with the mark of the 'Régisseur,' Henri Clavel, and the Paris mark. 
Tables of the Alphabetical Date-letters used in Paris from 1461-2-1783-4.

\begin{tabular}{|c|c|c|c|}
\hline A & $\begin{array}{c}\text { LOUIS XI. } \\
1461-2\end{array}$ & $1484-5$ & $\begin{array}{c}1506-7 \text { (Feb. } 5,1506 \\
-7 \text {-Dec. } 1507 \text { ) }\end{array}$ \\
\hline B & 14623 & $1485-6$ & $\begin{array}{c}1507-8 \text { (from Dec. } \\
10,1507)\end{array}$ \\
\hline $\mathrm{C}$ & $1463-4$ & $1486-7$ & $1508-9$ \\
\hline $\mathrm{D}$ & $1464-5$ & $1487-8$ & $1509-10$ \\
\hline $\mathrm{E}$ & $1465-6$ & $1488-9$ & $1510-1$ \\
\hline $\mathrm{F}$ & $1466-7$ & $1489-90$ & $1511-2$ \\
\hline G & $1467-8$ & $1490-1$ & $1512-3$ \\
\hline $\mathrm{H}$ & $1468-9$ & $1491-2$ & $1513-4$ \\
\hline I & $1469-70$ & $1492-3$ & $1514-5$ \\
\hline K & $1470-1$ & $1493-4$ & $\begin{array}{c}\text { FRANCIS I. } \\
151 \check{-}-6\end{array}$ \\
\hline L & $1471-2$ & 1494-כ & $1516-7$ \\
\hline $\mathrm{M}$ & $1472-3$ & $149 \check{-6}$ & $1517-8$ \\
\hline $\mathrm{N}$ & $1473-4$ & $1496-7$ & $1518-9$ \\
\hline 0 & $1474-5$ & $1497-8$ & $1519-20$ \\
\hline $\mathrm{P}$ & $1475-6$ & $\begin{array}{c}\text { LOUIS XII. } \\
1498-9\end{array}$ & $1520-1$ \\
\hline $\mathrm{Q}$ & $1476-7$ & $1499-1500$ & $1521-2$ \\
\hline $\mathrm{R}$ & $1477-8$ & $1500-1$ & $1522-3$ \\
\hline $\mathrm{S}$ & $1478-9$ & $1501-2$ & $1523-4$ \\
\hline $\mathrm{T}$ & $1479-80$ & $1502-3$ & $1524-\tilde{~}$ \\
\hline $\mathrm{U}$ & $1480-1$ & $1503-4$ & $1525-6$ \\
\hline $\mathrm{X}$ & 1481-2 & $1504-5$ & $1526-7$ \\
\hline $\mathrm{Y}$ & $\begin{array}{c}1482-3 \\
\text { CHARLES VIII. } \\
1483-4\end{array}$ & $\begin{array}{c}1506-7 \text { (to Feb. } 5, \\
1506-7)\end{array}$ & $1527-8$ \\
\hline
\end{tabular}


Tables of the Alphabetical Date-letters used in Paris from 1461-2-1783-4-continued.

\begin{tabular}{|c|c|c|c|}
\hline A & $1529-30$ & $1552-3$ & $1575-6$ \\
\hline B & $1530-1$ & $1553-4$ & $1576-7$ \\
\hline $\mathrm{C}$ & $1531-2$ & $1554-5$ & $1577-8$ \\
\hline $\mathrm{D}$ & $1532-3$ & $1555-6$ & $1578-9$ \\
\hline $\mathrm{E}$ & $1533-4$ & $1556-7$ & $1579-80$ \\
\hline $\mathrm{F}$ & 1534-5 & $1557-8$ & $1580-1$ \\
\hline$G$ & $1535-6$ & $1558-9$ & $1581-2$ \\
\hline $\mathrm{H}$ & $1536-7$ & $\begin{array}{c}\text { FRANCIS II. } \\
1559-60\end{array}$ & $1582-3$ \\
\hline$I$ & $1537-8$ & $\begin{array}{l}\text { CHARLES IX. } \\
1560-1\end{array}$ & $1583-4$ \\
\hline K & $1538-9$ & $1561-2$ & $1584-5$ \\
\hline $\mathrm{L}$ & $1539-40$ & $1562-3$ & $1585-6$ \\
\hline $\mathbf{M}$ & $1540-1$ & $1563-4$ & $1586-7$ \\
\hline $\mathrm{N}$ & $1541-2$ & $1564-5$ & $1587-8$ \\
\hline 0 & $1542-3$ & $1565-6$ & $1588-9$ \\
\hline $\mathrm{P}$ & $1543-4$ & $15666-7$ & $\begin{array}{c}\text { HENRY IV. } \\
1589-90\end{array}$ \\
\hline Q & $1544-5$ & $1567-8$ & $1590-1$ \\
\hline $\mathrm{R}$ & $1545-6$ & $1568-9$ & $1591-2$ \\
\hline & $1546-7$ & $1569-70$ & $1592-3$ \\
\hline $\mathrm{T}$ & $\begin{array}{l}\text { HENRY II. } \\
1547-8\end{array}$ & $1570-1$ & $1593-4$ \\
\hline $\mathrm{U}$ & $1548-9$ & $1571-2$ & 1594-5 \\
\hline$X$ & 1549-ฮ̃0 & $1572-3$ & $1595-6$ \\
\hline $\mathrm{Y}$ & $1550-1$ & $1573-4$ & $1596-7$ \\
\hline $\mathrm{Z}$ & $1551-2$ & $\begin{array}{c}\text { HENRY III. } \\
1574-5\end{array}$ & $1597-8$ \\
\hline
\end{tabular}


Tables of the Alphabeticat Date-letters used in Paris from 1461-2-1783-4-continued.

\begin{tabular}{|c|c|c|c|}
\hline A & $1598-9$ & $1621-2$ & $1645-6$ \\
\hline B & $1599-1600$ & $1622-3$ & $1646-7$ and $47-8$ \\
\hline $\mathrm{C}$ & $1600-1$ & $1623-4$ & $1648-9$ \\
\hline $\mathrm{D}$ & $1601-2$ & $1624-5$ & $1649-50$ \\
\hline $\mathrm{E}$ & $1602-3$ & $1625-6$ & $1650-1$ \\
\hline $\mathrm{F}$ & $1603-4$ & $1626-7$ & $16 \check{1-2}$ \\
\hline $\mathrm{G}$ & $1604-5$ & $1627-8$ & ' $1652-3$ \\
\hline $\mathrm{H}$ & $1605-6$ & $1628-9$ & $1653-4$ \\
\hline I & $1606-7$ & $1629-30$ & $1654-5$ \\
\hline K & $1607-8$ & $1630-1$ & $1655-6$ \\
\hline $\mathrm{L}$ & $1608-9$ & $1631-2$ & $1656-7$ \\
\hline $\mathrm{M}$ & $1609-10$ & $1632-3$ and $33-4$ & $1657-8$ \\
\hline $\mathrm{N}$ & $\begin{array}{l}\text { LOUIS XIII. } \\
\text { 1610-1 }\end{array}$ & $1634-5$ & $16 \tilde{8}-9$ \\
\hline $\mathrm{O}$ & $1611-2$ & $1635-6$ & $\begin{array}{c}1659-60 \text { (Dec. } 11, \\
1659 \text {-July } 1,1660)\end{array}$ \\
\hline $\mathrm{P}$ & $1612-3$ & $1636-7$ & $\begin{array}{c}1660-1 \text { (from July } \\
1,1660 \text { ) }\end{array}$ \\
\hline $\mathrm{Q}$ & $1613-4$ & $1637-8$ & $1661-2$ \\
\hline $\mathrm{R}$ & $1614-5$ & $1638-9$ & $1662-3$ \\
\hline $\mathrm{s}$ & $1615-6$ & $1639-40$ & $1663-4$ \\
\hline $\mathrm{T}$ & $1616-7$ & $1640-1$ & $1664-5$ \\
\hline $\mathrm{U}$ & $1617-8$ & $1641-2$ & $1665-6$ \\
\hline $\mathrm{X}$ & $1618-9$ & $1642-3$ & $1666-7$ \\
\hline $\mathrm{Y}$ & $1619-20$ & $\begin{array}{c}\text { Lours XIV. } \\
1643-4\end{array}$ & $1667-8$ \\
\hline $\mathrm{Z}$ & $1620-1$ & $1644-5$ & $1668-9$ \\
\hline
\end{tabular}


Tables of the Alphabetical Date-letters used in Paris from 1461-2-1783-4-continued.

\begin{tabular}{|c|c|c|c|}
\hline A & $1669-70$ & $1694-5$ & $1717-8$ \\
\hline B & $1670-1$ & $1695-6$ & $1718-9$ \\
\hline $\mathrm{C}$ & $1671-2$ & $1696-7$ & 1719-20 \\
\hline $\mathrm{D}$ & $1672-3$ & $1697-8$ & 1720-1 \\
\hline $\mathrm{E}$ & $1673-4$ & 1698-9 & $1721-2$ \\
\hline $\mathrm{F}$ & $1674-5$ & $1699-1700$ & $1722-3$ \\
\hline G & $1675-6$ & $1700-1$ & $1723-4$ \\
\hline H & $1676-7$ & $1701-2$ & 1724-5 \\
\hline I & $1677-8$ & $1702-3$ & 1725-6 \\
\hline K & $\begin{array}{l}1678-9 \text { and } 79 \text { (July } \\
1678-J a n .1,1679- \\
80\end{array}$ & $1703-4$ & $1726-7$ \\
\hline $\mathrm{L}$ & $\begin{array}{c}1680-1 \text { (Jan. } 1,1679 \\
-80-J u l y, 1681)\end{array}$ & 1704-5 & $1727-8$ \\
\hline $\mathrm{M}$ & $\begin{array}{c}1681-2 \text { (from July, } \\
1681 \text { ) }\end{array}$ & $1705-6$ & $1728-9$ \\
\hline $\mathrm{N}$ & $1682-3$ & $1706-7$ & $1729-30$ \\
\hline $\mathrm{O}$ & $1683-4$ & $1707-8$ & $1730-1$ \\
\hline $\mathrm{P}$ & $1684-5$ & $1708-9$ & $1731-2$ \\
\hline $\mathrm{Q}$ & 1685 & $1709-10$ & $1732-3$ \\
\hline $\mathrm{R}$ & $1686-7$ & $1710-1$ & $1733-4$ \\
\hline $\mathrm{S}$ & $1687-8$ & $1711-2$ & 1734-5 \\
\hline $\mathrm{T}$ & $1688-9$ & $1712-3$ & $1735-6$ \\
\hline $\mathrm{U}$ or $\mathrm{V}$ & $1689-90$ & $1713-4$ & $1736-7$ \\
\hline$X$ & $\begin{array}{c}1690-1 \text { and } 1691-2 \\
\text { (July 20,1690- } \\
\text { Oct. 13, 1692) }\end{array}$ & 1714-5 & $1737-8$ \\
\hline $\mathbf{Y}$ & $\begin{array}{c}1692-3 \text { (from Oct. } \\
13,1692 \text { ) }\end{array}$ & $\begin{array}{l}\text { LOUIS XV. } \\
1715-6\end{array}$ & $1738-9$ \\
\hline $\mathrm{Z}$ & $1693-4$ & $1716-7$ & $1739-40$ \\
\hline
\end{tabular}


Tables of the Alphabetical Date-letters used in Paris from 1461-2-1783-4-continued.

\begin{tabular}{|c|c|c|c|}
\hline A & $\begin{array}{c}1740-1 \text { and } 41-2 \\
\text { (Dec. } 29,1740- \\
\text { Mar. } 9,1742)\end{array}$ & $1764-5$ & \\
\hline B & $\begin{array}{c}\text { 1742-3 (from Mar. } \\
\text { 9, 1742-3-July, } \\
1743 \text { ) }\end{array}$ & $1765-6$ & \\
\hline C & $\begin{array}{c}1743-4 \text { (from July, } \\
1743)\end{array}$ & $1766-7$ & \\
\hline $\mathrm{D}$ & $1744-5$ & $1767-8$ & \\
\hline $\mathrm{E}$ & $1745-6$ & $1768-9$ & \\
\hline $\mathrm{F}$ & $1746-7$ & $1769-70$ & \\
\hline G & $1747-8$ & $1770-1$ & \\
\hline $\mathrm{H}$ & $1748-9$ & $1771-2$ & \\
\hline I & $1749-50$ & $1772-3$ & \\
\hline $\mathrm{K}$ & $1750-1$ & $1773-4$ & \\
\hline $\mathrm{L}$ & $1751-2$ & $\begin{array}{l}\text { LOUIS XVI. } \\
1774-\tilde{5}\end{array}$ & \\
\hline $\mathrm{M}$ & $1752-3$ & $177 \check{\jmath}-6$ & \\
\hline $\mathrm{N}$ & $1753-4$ & $1776-7$ & \\
\hline $\mathrm{O}$ & 17ð4-כَ & $1777-8$ & \\
\hline $\mathrm{P}$ & $1755-6$ & $1778-9$ & \\
\hline Q & $1756-7$ & $1779-80$ & \\
\hline $\mathrm{R}$ & $1757-8$ & $1780-1$ & \\
\hline $\mathrm{S}$ & $1758-9$ & $1781-2$ & \\
\hline $\mathrm{T}$ & $1759-60$ & $1782-3$ & \\
\hline $\mathrm{U}$ or $\mathrm{V}$ & $1760-1$ & 1783-4 (from July & \\
\hline $\mathrm{X}$ & $1761-2$ & & \\
\hline$Y$ & $1762-3$ & & \\
\hline $\mathrm{Z}$ & $1763-4$ & & \\
\hline
\end{tabular}


CHAP. II.] MARKS USED BY THE FARMERS GENERAL. 45

List of the Farmers General of the Duties and their MARKS FROM 1672.

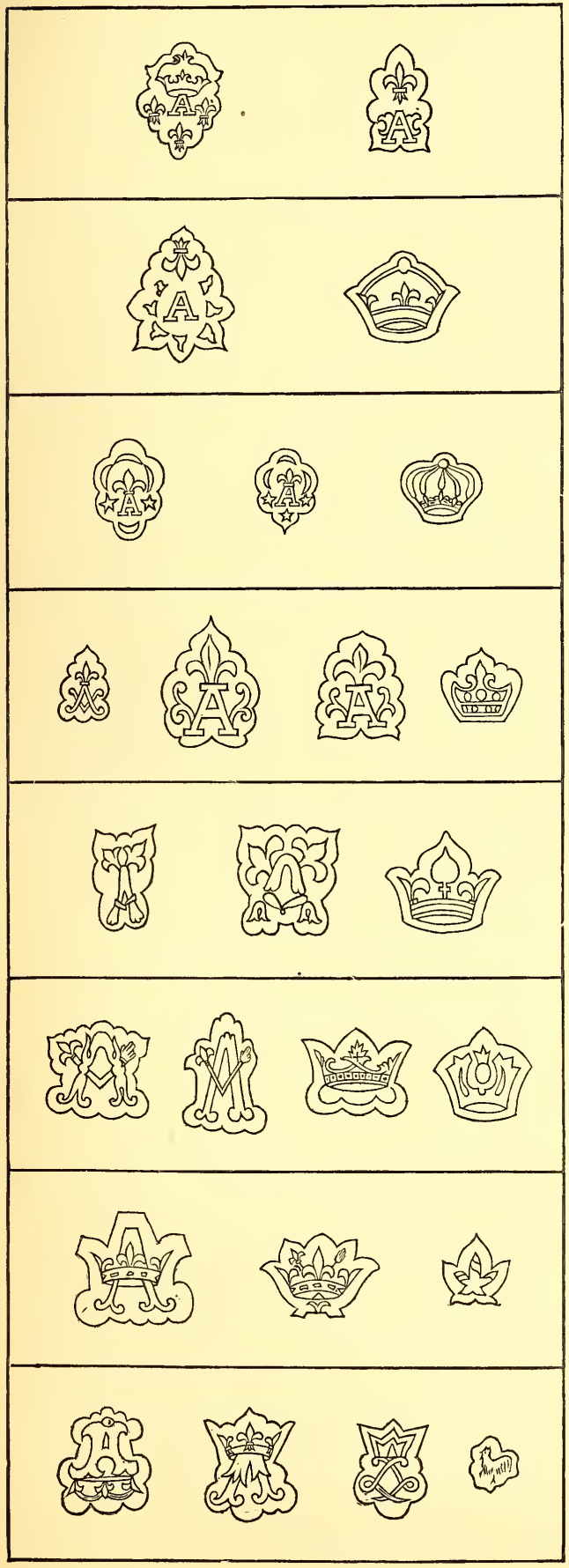

Vincent F'ortier, Oct. 1672-Oct. 1680.

Adjudicataire du droit de marque.

Paul Brion de Saussoy, Oct. 1680-1684.

Sous-Fermier.

Etienne Ridereau, $168 \pm$ $-1687$.

Fermier.

Jacques Leger, Oct. 1687-Dec. 1691.

Fermier.

Pierre Pointeau, Dec. 1691-1698.

Fermier-Général.

Perrine, 1698-1703.

Fermier-Général.

Etienne Baligny, 1703 -Dec. 1713.

Fermier-Général.

Florent Sollier, Dec. 1713-Oct. 1717.

Sous-Fermier. 
List of the Farmers General, ETC.-continued.

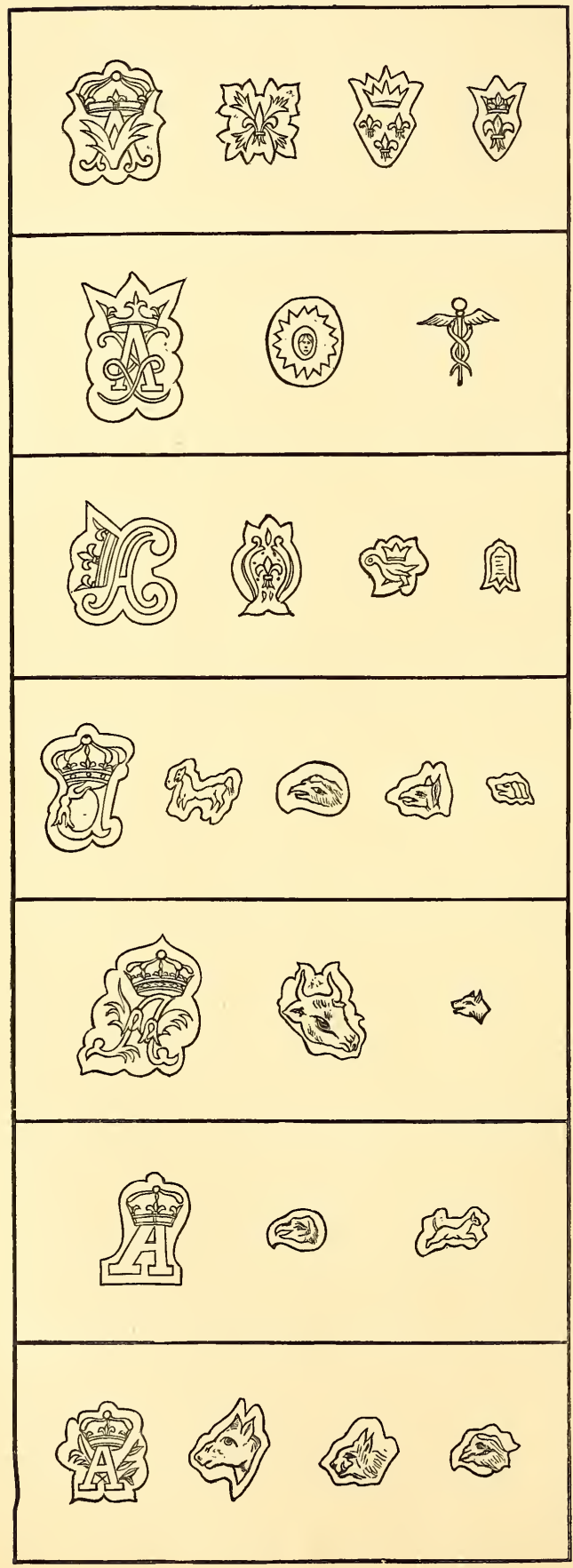

Etienne de Bouges, Oct. 1717-1722.

Fermier des droits de la marque.

Charles Cordier, 1722Nov. 1726.

Chargé de la Régie des Fermes Générales Unies.

Jacques Cottin, Dec. 1726-Oct. 1732.

Sous-Fermier.

Hubert Louvet, Oct. 1732-Oct. 1738.

Sous-Fermier.

Robin, Oct. 17381744.

Sous-Fermier.

Antoine l'Echaudel, 1744-Feb. 17 o0.

Fermier.

Julien Berthe, Feb. 1750-Oct. 1756.

Sous-Fermier. 
CHAP. II.] MARKS USEI BY THE FARMERS GENERAL. 47

List of the Farmers GeneraL, ETo.—continued.

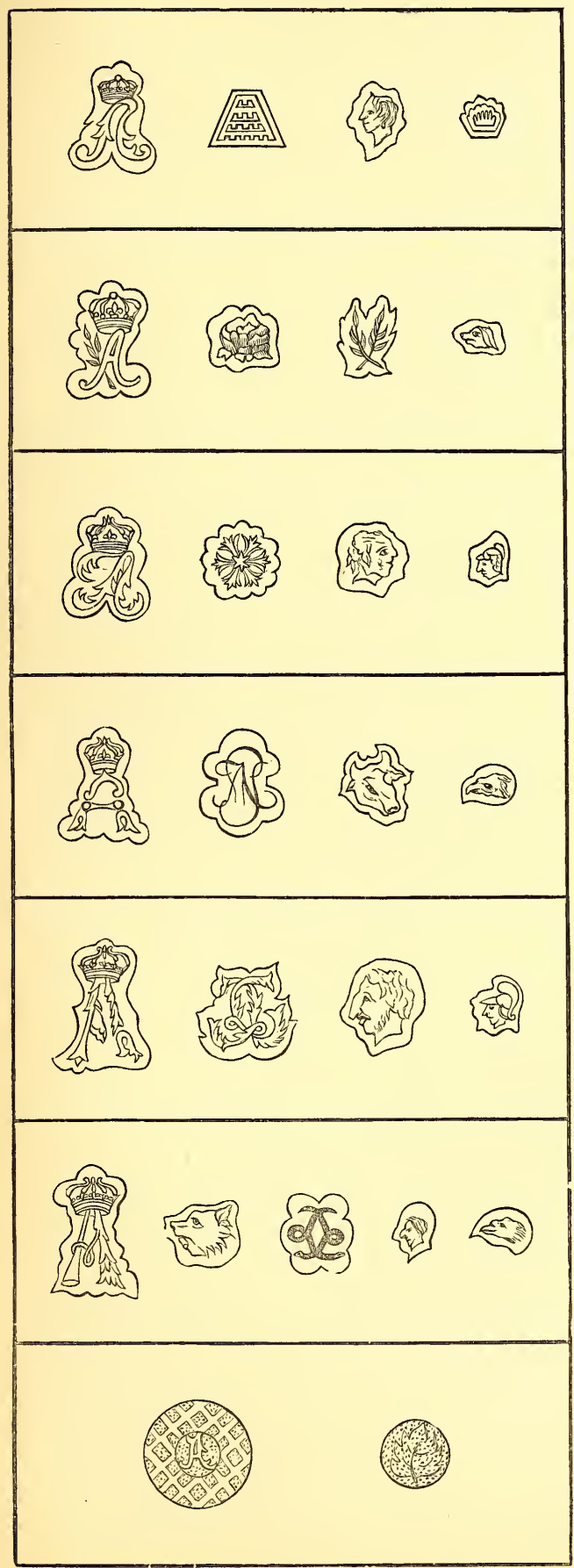

Eloi Brichard, Oct. 1756-Oct. 1762.

Sous-Fermier.

Jean Jacques Prevost, Oct. 1762-Oct. 1768. AdjudicataireGénéral.

Julien Alaterre, Oct. 1768-Oct. 1774.

AdjudicataireGénéral.

Jean Bte. Fouache, Oct. 1774-1780.

Régisseur pour le compte du Roi.

Henri Clavel, 17801783.

Régisseur-Général.

H. Clavel, 1783-1789.

By decree of 31 Aug. 1782.

Calandrin, 1789 . 
Alphabetical List of some of the best known Paris Goldsmiths of the Eighteenti CeNtury, together with the NAMEs of THE Wardens of the GUILD IN THE EARLIER YeArs. THE DATES ARE TAKEN FROM THOSE ASSIGNED BY THE BARON J. Pichon to various articles IN the Lenoir DoN IN the Musée DU Louvre; from the Ancient Plate sold in the Pichon and Eudel Collections; AND from other sources. The SPELLING OF THE NAMES IS IN SOME CASES UNCERTAIN.

A.

Henri Alain, 1758.

David André, 1731.

P. J. Antoine, reçu 1739. 1743.

Antoine Aubert, garde 1759.

Thomas Aubry, garde 1703-4.

Chas. Audry ou Haudry, garde 1706-7.

Robert J. Auguste, reçu $175 \%$. $1767,1770,1776$.

B.

Fred. Joseph Bachman, 1782.

Claude Ballin, nephew of Claude the elder (Louvre), reçu 1688, d. 1754; garde 1701-2.

Jacques Lallin, goldsmith to Louis XIV., nephew of Claude, 17191750. 1737.

Edme Pierre Balsac, 1744, 1766.

Jean Bastiers, garde 1705-6.

Robert Baucher, 1724.

J. F. Mathis de Beaulieu, pupil and successor to J. George, reçu 1768. 1777.

P. J. Bellangé, reçu 17õ4. 1762.

Chas. Etienne Berrubé, 1783.

Martin Berthe, 1722.

Nicholas Besnier, goldsmith to Louis XV., reçu 1715. 1728, 1737. J. E. Blerzy, reçu 1768. 1774, 1781. Michel Réné Bocher, 1787.

Jacques Ant. Bonhomme, 1777. Pierre Fras. Bonnestraine, 1718. Ant. Boullier, 1775, 1783, 1784. Claude Isaac Bourgoin, 1783.

Simon Bourguet, 1744, 1748, 1750.
Louis J. M. Bouty, 1778.

Jacques de Boy, 1776.

Pierre Jean Briceau, garde 1759.

Henri Nicolas de Brie, 1766.

Antoine Brigal, 1780.

Chas. Alex. Buillerot, 1787.

Pierre Desiré Bullot, 1778.

Pierre Etienne Buron, reçu 1735.

C.

Thomas Chancelier, reçu 1736. 1782.

Claude Charvet, 1741.

Remy Chatria, 1728, 1731.

Antoine Fras. Chéret, garde 1708-9.

J. B. Chéret, 1763, 1766, $178 j$.

Daniel de Clêves, garde 1703-4.

Mathieu Coiny, reçu 175̃. 1763, 1772.

Michel Colas, garde 1734-5.

François Coppin, garde 1708-9.

J. B. de Courdemanche, 1787.

Thomas Cousinet, 1769.

Ch. François Croze, 1725.

\section{D.}

R. L. Dany, 1779, 1786.

Jean François Dapché, reçu 1751.

Gabriel Dardel, 1719.

Jacques Daumy, 1785, son-in-law of M. J. Tugot.

Paul Delafosse, garde 1702-3.

Pierre Delahaye, garde 1700.

Nicolas Delaize, garde 1710.

C. N. Delanoy, 1775 .

Jean Baptiste Delens, 1736.

Jacques Joseph Demay, 1777. 
Charles Despots, 1729.

François Dubellay, garde 1710. 1704.

Jean Duché, 1769.

J. Ducrollay, reçu 1734. 1754, 1761.

J. C. Ducrollay, reçu 1737. 175う, 1761.

Jean Duhamel, 1729.

Adrien Mathieu Dumee, 1761.

Edme Duplessis, 1719.

Nic. Durier, 1787.

Antoine Dutry, 1767.

\section{F.}

Jacques Favre, 1774.

Réné Pierre Ferrier, 1782.

Jean François Forty, 1767.

Denis Franckson, 1770. 1782, 1787.

\section{G.}

Jean Gaillard, 1747.

Claude Fras. Gauché, 1740.

Fras. Gauchelet, reçu 1692; d.1715.

Simon Gaucher, 1721.

J. George, 1752, 1762.

Fras. Thos. Germain, reçu 1748; failed 1765 ; son of Thomas.

Pierre Germain II., reçu 1744; garde $1759 ; d .1783$.

Thomas Germain, reçu $1720 ; d$. 1748. 1733.

Ambroise Godin, garde 1705-6.

Denis Germain Godin, garde 17001701.

Jean Fras. Goget, 1755.

Germain Goujon, 1721.

Pierre Nicolas Grebende, 1746.

Antoine Fras. Grouvelle, garde 1734-5.

Louis Antoine Grouvelle, 1770, 1785 .

Claude Guignard, 1778.

\section{H.}

Jean Hanier, garde 1709-10.

Chas. Cesar Haudry, 1745.

Louis Antoine Herbault, 1725.
J.

Guillaume Jacob, garde 1700.

Marc Etienne Janety, 1777.

Richard Jarry, garde 1735. 1736.

Antoine Jossey, 1714.

François Joubert, 1762, 176ら, 1766, 1767, 1777, 1781, 1785.

J. E. Julliot, 1787.

L.

Pierre Fras. de Lafons, garde 1760.

Paul de Lafosse, garde 1702.

Thos. Leonard Lagneau, reçu 1694; garde $1720 ; d .1750$.

Leonard Lagneau, reçu 1722; garde 173j-6 (son of T. L. Lagneau above).

François Lains, garde 1707-8.

Antoine Lambert, 1768.

Pierre Landell, 1730.

Marcoult Langlois, 1725.

Bart. Bernard Lebastier, garde 1700-1.

François Lebastiers, garde 1708-9.

Jean Leblanc, 1744.

Louis Legros, 1736.

Claude Lemire, 1729.

Pierre Jean Lenfant, reçu 1772. 1776.

LouisLenhendrick, reçu 1747. 1760, 1764 ; garde 1759.

Alexandre Lenoir, 1729.

Noel Léonard, reçu 1714.

Jean Malquis Lequin, reçu 1748.

Rene Leriche, garde 1735-6.

Jean Pierre Leroy, garde 1735-6.

Charles Levesque, 1734.

Jullien Levesque, garde 1703-4.

Nic. Des Lions, garde 1759 .

Alexis Loir, 1749.

J. B. Loir, 1701.

Louis Loir, 1710.

Abraham Lorrin, garde 1710.

Jean Lorrin, garde 1700.

Guillaume Lucas, garde 1700-1. 
M.

Mathieu de Machy, 1753.

P. F. Marchand, 1768.

Nic. Marcoult, garde 1734-5.

Jacques Pierre Marteau, 1755.

Gregoire Masse, 1708.

J. A. Meissonnier, reçu 1725. 1735.

Louis Mermant, 1776.

Alex. Nic. le Moine, 1787.

Fras. Michel Montaigne, 1780-89.

Michel Fras. Montaigne, 1789.

Etienne Moreau, reçu 1753.

Simon Morel, garde 1735-6.

Jean Louis Morel, garde 1759.

Réné Morice, 1701-2.

Louis Mothet, 1775 .

J. Moynat, reçu 1745. 1754, 1761.

Robert Moynart, 1725.

N.

Antoine de Saint Nicholas, 1716. 1726.

Jean Baptiste Nolin, 1759.

O.

J. L. D. Outrebon, 1773. 1782, 1784.

Nic. Outrebon, 1733.

\section{P.}

Lambert Payen, garde 1709.

Julien Boulogne Petit, 1768.

Octave Cesar Petit, garde 1704-5.

Jacques Pijart, garde 1702-3.

B. Pillieu, reçu 1774. 1779.

Antoine Plot. 1733.

Jacques Pollet, 1729.

Adrien Polly, garde 1706-7.

Jean Simon Pougnet, 1768.

Jacques Provost, garde 1705-6.

Q.

Jean Quin, 1716. 1725.

R.

Simon Reconseil, 1751.

Louis Regnard, 1733, 1743, 1769.

Fras. Renard, garde 1706-7.

Fras. Rigal, reçu 1720. 1731.
C. Roettiers, 1723-1740.

Jacques Roettiers, b. 1707, reçu 1733 , garde 1759 , d. 1784 , sonin-law to N. Besnier.

Jean Roger, 1780.

Guillaume Fras. Rolland, 1777.

Chas. Dominique Rondé, garde 1759.

Louis Joseph Rondot, 1781.

Alex. de Roussy, $1765,1777$.

Daniel Royez, garde 1707-8.

\section{S.}

J.N. Sacher, reçu 1783. 1785, 1789.

C. B. Sageret, reçu 17 o2. 1764 ; goldsmith to the Duc d'Orleans.

Alex. Savart, 1777.

Pierre Nic. Somme, 1777.

Paul Soulaine, 1726.

Ch. Spriman, 1776, 1778.

Syrieys, 1729.

T.

I. F. A. Taunay, reçu 1761. 1773.

Simon Thierce, 1715.

Claude Tripart, garde 1707-8.

Jean Louis Tourteau (Gobelins), reçu 1757.

Marie Joseph Tugot, 1785; royal manufacturer, with his son-inlaw Daumy, of gold plate inlaid with plaques.

Joseph Turmel, garde 1704-5̃.

V.

A. J. M. Vachette, reçu 1779. $1789,1806$.

André Valette, garde 1709-10.

J. C. Vanconverberghen, 1775, 1784.

Philipes Vandives, garde 1701-2.

Jacques Fras. Varin, 1761.

Balthazar Philipes Vendive, garde 1735-6.

Claude de Villaire, garde 1702-3.

Antoine Jean de Villeclaire, reçu 1750. 1764.

François de Villers, reçu 1673 ; $d$. 1715. 


\section{CHAPTER III.}

\section{PROVINCIAL MARKS TILL 1789.}

Ancient provincial hall-marks-The Mint letters of provincial centresThe marks of 1783 - The standards of Burgundy and LorraineExamples of old provincial marks-Table of arms of towns where plate was made before 1783-Table of the marks used under the administration of $\mathrm{Jn}$. Bte. Fouache, 1774-1780-Table comparing Paris and Provincial marks under H. Clavel-Table of the town marks used from 1783-1789.

Most of the ordinances that have been already considered apply to the goldsmiths of the provinces as well as those of Paris. Some of the provincial communities were, as we have seen, of ancient foundation. If Marseilles and Bordeaux alone can trace the history of their goldsmiths' guilds to the thirteenth century, Cambrai, Puy-en-Velay, Rouen, and Troyes can go back as far as the fourteenth, whilst Toulouse and Montpellier both obtained royal recognition in the fifteenth century.

Goldsmiths must have worked in many of these places even earlier, for Philippe le Hardi in 1275 directs the goldsmiths everywhere to mark their work with the seign of the town in which they dwell.

This mark appears in very many cases to have been a shield of the town arms. Montpellier early in the fifteenth century, when adopting a date-letter, appoints that it shall be "reproduced beneath the shield of arms of the town " on the work. The most ancient specimens known of the work of Strasbourg craftsmen bear for town mark a shield with a bend, which is the armorial 
bearing of that city; whilst a very ancient spoon with an acorn head, found at Rouen, and now preserved in the South Kensington Museum, bears in the bowl a lamb and flag. A copper plate in the Musée de Cluny preserves the names and marks of no less than 154 goldsmiths of Rouen in 1408. These marks, which are however of little real use, for probably no work bearing them remains at the present day, give the lamb and flag of Rouen on a plain diamond shield with the maker's symbol in a smaller diamond or circle or small shield immediately under and touching it. Besides this there is in all case's a letter in black-letter capitals alongside the first mark or double mark already described. This capital letter is always the initial letter of the goldsmith's Christian name, his family name being no doubt signified by the device under the lamb and flag. In some places they seem to have used, at least in early times, the first two letters of the name of the town, or the first letters of each syllable of it, or sometimes its first and last letters.

The author is inclined to attribute the mark consisting of the letters $\overline{\mathbf{M}} \mathbf{O} \dot{\mathbf{P}}$ in Lombardic characters, which occurs on a basin or deep plate of the fourteenth century in the South Kensington Museum, to Montpellier. A M in the same style of lettering seems at one time to have been used at Amiens. Whether the arms or letters were used, a date-letter was often added in the course of the fifteenth or later centuries; indeed it was the great number of different alphabets in use, and the confusion thereby created that at length occasioned the abolition of all dateletters in 1783, and the substitution of a new and peculiar mark for each place to which the year should be added. We might almost infer from this that some of the provincial guilds, following the example of Paris, had used no mark except an alphabetical letter. 
This new town mark of 1783 is unfortunately no clue to any older one; for it was in hardly any case an armorial bearing, but some quite modern and fanciful device. A long list of them is given by Lacroix, and, for what they are worth, they are reproduced at the end of this chapter; though, as they were in use only from 1784 to 1789 , five troublous years in which little plate could have been made, it must be confessed that they are of small interest.

The shield of arms, then, accompanied or not by a date-letter, or in some instances, perhaps, a date-letter only, was the usual town mark until 1784 ; and from 1784 to 1789 this new modern device, accompanied by the last two figures of the year, or else some small, secret, and variable character.

In the work of Lacroix will be found the arms of a large number of old French provincial corporations ; but unfortunately the arms of these guilds seem to be no clue at all to the hall-marks used by them. Neither the $\mathrm{NE}$ 'avec une hermine cravatée' of ancient Nantes, (or perhaps of Vannes near Nantes,) nor the bend used at Strasbourg are even to be guessed at from the arms given by Lacroix as those of the goldsmiths' guilds in those cities, nor from the devices adopted by them in 1783 . The lamb and flag of Rouen is one of the rare exceptions.

A better clue is to be found from 1672, owing to the fact that from that time the mark of the farmer of the duty, or poinçon de charge, should be found on provincial French, as on Paris, plate in addition to the town-mark, maker's mark, and date-letter.

This mark was the mint letter of the town, and at one or other of the mint towns, of which there seem to have been some twenty or thirty, probably one for each of the provinces into which France was divided from the time 
of Louis XIV., plate must have paid duty and received the mark of the charge and discharge by way of receipt.

For the complete table of the marks, Parisian and provincial, in use during the administration of Fouache from 1774 to 1780 , appended to this chapter, the author is indebted to the kindness of the Baron Jerome Pichon, who is, without doubt, the highest authority on these points.

This table gives the mint-letters of the towns that were at that time centres of jurisdiction, but it will be remarked that some few letters of the alphabet are omitted. If these are restored from other sources, we shall probably be in possession of a nearly complete list of all the towns in France that have ever been of much plate-making or plate-marking consequence.

These missing letters are F, Q, T, V, and W.

$\mathrm{F}$ is the letter for Angers, the mint at which place was suppressed in 1738 .

$\mathrm{Q}$ was used at Perpignan.

$\mathrm{T}$ once stood for Nantes.

$\mathrm{V}$ seems for some time (after 1690) to have been in use at Amiens.

W used at Lille in some part of the eighteenth century.

To this list may be added a double $B$, which was in use at Strasbourg as the double A was at Metz.

It would seem that no letter was used at Pau for the province of Bearn ; possibly a cow was the local device for that town.

Lastly, the letters MA, linked by being placed one over the other, sometimes stand for Marseilles.

The fashion of the provincial mint letters used for the poinçon de charge probably followed the Paris use; thus if the Paris A was accompanied by three fleurs-de- 
lis, so probably were the provincial letters in use at the same period. Under Fouache and Clavel this was certainly so.

We have also appended to this chapter, for the purpose of illustrating this point, a fac-simile of an engraving given by M. Raibaud of the marks in use in Paris and one or two other large towns shortly before the abolition of taxes in 1791, but it cannot be taken as an accurate representation of the letters. It serves, however, to show the sort of correspondence which was then and probably always preserved between the fashion of the Parisian and provincial Mint letters of the poinçon de charge. The author has been able to assign the charge and discharge marks for Grénoble found on a spoon made by one Fauche of that place to the interval between 1762 and 1768, from their obvious relationship to those used in Paris under J. J. Prevost, the farmer-general of that date.

These tables, and one of the arms of the towns in which plate was chiefly made, will be all that the amateur or collector of old French plate will require to enable him to identify the origin of almost any specimens of provincial work older than 1784 that come under his notice.

It is not likely that any great amount of plate was made anywhere but in Paris, at all events for the last two centuries.

Some handsome eighteenth-century French plate was sold at Messrs. Christie and Manson's sale rooms in London, the auction mart which corresponds in importance to the Hotel Drouot, amongst "the Gregory Heirlooms" in the summer of 1878 , bearing four marks, viz., maker's mark, a date-letter, a Roman capital L, accompanied by a very small fleur-de-lis or trefoil, being no doubt the duty mark for Bayonne, and a fleur-de-lis, which was 
either the mark de décharge or a town mark then used at Bayonne.

A few words must be added about the provincial marks introduced in 1783 in lieu of those previously in use. It would have been better to give them in a separate chapter but for the two facts that they, like the earlier marks, are found in conjunction with the duty marks, and that they only lasted for about six years. If included, therefore, in the present chapter, French hall-marking is carried down to the time of the abolition of taxes, and with them of all old plate-marks, in 1791.

It has been a question whether the tables of these marks, as given by Raibaud and Lacroix, should be engraved afresh for this handbook, or whether the names of the towns, with a plain description of their marks, would not be an almost better indication. The actual marks used differ very much from the representations of them as given in the mint tables; besides which, though the marks in the tables are called fixed and invariable, in point of fact they all of them, including the letter $\mathrm{P}$ for Paris, seem to have varied in design each year.

They are given, however, at the -end of this chapter, and as before remarked, for what they are worth. It will be remembered that the mint letter of one or other provincial jurisdiction should be found with them. This may often serve to clear up any doubt as to the town mark, by adding an indication of the local centre to which it belonged.

In conclusion, as to the standards in use in the provinces of France. They were usually those of Paris, and in the case of gold this is so almost without exception. Burgundy and Lorraine, however, each had an inferior standard of their own for silver, although recognising the French standard as well. 
That of Burgundy was 11 den. 8 grs. fine, with a remedy of 2 gr., and was used at Besançon, Lille, and other places. The silver standard of Lorraine was lower, being only 9 den. 12 gr. fine, without any remedy. This was worked at Nancy and Bar-le-Duc. Strasbourg too had standards of its own; $18 \frac{1}{2}$ carats for gold, with a small remedy; and 9 den. 20 grs., with a remedy of 2 grs., for silver.

\section{EXAMPLES OF FRENCH PROVINCIAL MARKS.}

1001 Mark, probably Montpellier, from bowl of the fourteenth century in the South Kensington Museum, London.

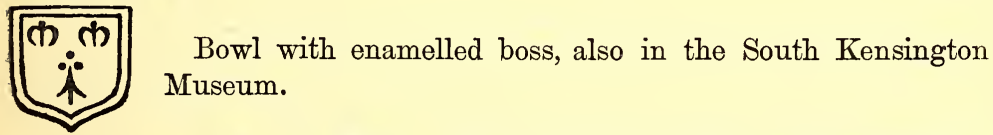

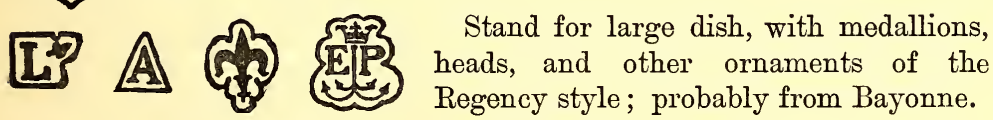

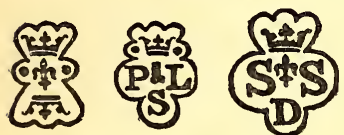

Pot-à-boire, with reeds, shells, and waves, of the Regency period; perhaps from Soissons. From the Pichon and Eudel Collections.

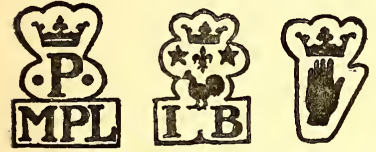

Ewer and basin, with contoured edge, ornamented with wreaths and straps, Louis XV. period; probably from Montpellier. Late Sir Richard Wallace, Bart.

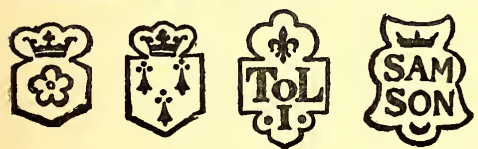

A similar one, probably by ' Samson' of 'Toulouse.' Late Sir Richard Wallace, Bart.

Gravy spoon, c. 1765, by Fauche of Gré-

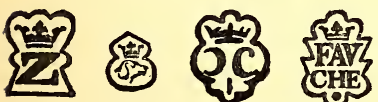
noble, with the 'poinçon de reconnaissance de deux CC adossé surmontée d'une couronne, pour Bourgogne.'

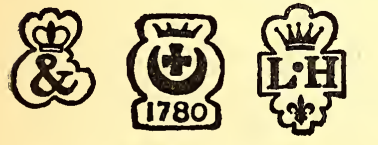

Pair of altar candlesticks. Made at Marseilles, jurisdiction de Aix. 
The following tables are used thus:-

In Table I. will be found the towns arms. In Table II. the mint letter of the poinçon de charge from 1672. Table III. will indicate the sort of comparison which should be made between the provincial and the Parisian mint letter in order to fix to which of the farmers or administrators of the taxes it relates. Lastly, Table IV. will give the town emblem which will be found between 1783 and 1789 instead of an earlier town mark, but still in conjunction with a mark of the charge.

\section{TABLE I.}

Arms of French Towns where Plate was made before 1783. THE TOWN OF JURISDICTION, THE MINT LETTER OF WHICH WOULD, SINCE 1672, BE FOUND AS A MARK IN CONJUNCTION WITH ANY OF THE FOLLOWING TOWN ARMS, IS GIVEN IN BRACKETS.

Abbeville (Amiens). Three bends within a bordure, on a chief three fleurs-de-lis.*

Agen (Bordeaux). Party per pale, 1st, a griffin or eagle displayed, holding in its claws a scroll; 2 nd, a castle.

Alais (Montpellier). A wing.

Aix (Aix). Five pallets, a chief of Jerusalem, Sicily and Anjou.

Alençon (Caen). Semy of fleurs-de-lis, a bordure charged with ten bezants.

Amiens (Amiens). Three branches, a chief of France.

Angers (Angers). A key in pale, on a chief two fleurs-de-lis.

Angoulême (Limoges). Semy of fleurs-de-lis, a bend compony gu. and arg. Another coat is, a city gate of two towers, and in chief a fleur-delis in a heart crowned.

Apt (Aix). A sheathed sword in pale, the girdle wound round the scabbard.

Arles (Aix). A lion sejant, the right paw raised, the tail between the legs. Arras (Lille). On a fess three rats, a mitre in chief and two saltire crosses in base. Another coat is, a lion having on his neck a shield semy of fleurs-de-lis with a label of four points, each charged with three towers. Avalon (Dijon). A single tower.

Avesnes (Lille). Bendy of six gu. and or, above the shield a hive surrounded by bees.

Aurillac (Riom). Three escallops, 2 and 1, on a chief 3 fleurs-de-lis.

* The coats of arms in this list are not described in minute heraldic detail, but only with a view to their identification when used as hall-marks. 
Autun (Dijon). A lion rampant, a chief of ancient Burgundy, which was three bends within a bordure. Another coat is a porcupine. A third was, three serpents in form of circles, their tails in their mouth,, on a chief two lions' heads affrontees erased.

Auxerre (Paris). Billety, over all a lion.

Bailleul (Lille). A cross vair, a lion in the first quarter.

Bar-le-Duc (Nancy). Semy of crosses-croslet fitchy, over all two fishes (bars) addorsed.

Bar-sur-Aube (Troyes). A bend, double cotised, potent and counterpotent.

Bayonne (Bayonne). A battlemented tower upon a wave, supported by two lions, one on each side, with their backs against two fir trees, a fleur-de-lis in chief between the two trees. Another coat is, a sword in pale, point downwards.

Beaucaire (Montpellier). Quarterly, or and gu.

Beaune (Dijon). A figure of Bellona upon a ground az., in right hand a sword, the left hand on the breast. After 1040. Our Lady leading the infant Jesus with her left hand, and holding a bunch of grapes in the right.

Beauvais (Paris). A pale fitchy.

Bergues St. Vinox (Lille). Party per pale, 1 a lion, 2 a fess, with a nail in base, on a canton a lion within a bordure.

Besançon (Besançon). An imperial eagle, holding in each of its claws two smail columns.

Beziers (Montpellier). Three fesses, on a chief 3 fleurs-de-lis.

Blois (Orleans). A fleur-de-lis. Another coat is, a porcupine bearing a shield with a fleur-de-lis fronting a fox bearing a similar shield.

Bordeaux (Bordeaux). A castle surmounted by a lion passant, at the foot of the walls a river charged with a crescent, on a chief 3 fleurs-de-lis.

Boulogne-sur-Mer (Amiens). A swan. Another coat is, Party per pale, 1st, a swan; 2nd, 3 torteaux, 2 and 1.

Bourg en Bresse (Dijon). A cross botonée.

Bourges (Bourges). Three sheep passant within an engrailed bordure; on a chief 3 fleurs-de-lis.

Brest (Rennes). Party per pale, 1st, 3 fleurs-de-lis, 2nd, ermine. Another coat is, a ship; a chief ermine.

Caen (Caen). Party per fess, 3 fleurs-de-lis, 2 and 1.

Cahors (Toulouse). A bridge of five arches, on which are five towers.

Calais (Amiens). A fleur-de-lis crowned, supported by a crescent. Another coat is, a vessel with sail furled.

Cambrai (Lille). A double-headed eagle, charged with an escutcheon with 3 lions, 2 and 1.

Carcassonne (Perpignan). Semy of fleurs-de-lis, a castle of three towers. Castres (Perpignan). Gules, 3 piles or, issuing from the dexter side.

Chalons-sur-Saone (Dijon). Three annulets, 2 and 1.

Chalons-sur-Marne (Reims). A cross between 4 fleurs-de-lis.

Charité, La (Bourges). Party per fess, in chief 3 towers, each surmounted by a fleur-de-lis, the base chequy. 
Chartres (Paris). Three bezants, each charged with an antique letter and a fleur-de-lis, a chief with 3 fleurs-de-lis.

Chateau Gonthier (Angers). No arms found.

Chateau Thierry (Reims). A castle of 5 towers between 3 fleurs-de-lis. Chatellerault (Poitiers). A lion rampant.

Chatillon sur Seine (Dijon). A square castle with corner towers, 3 fleurs-de-lis ranged in chief.

Chaumont en Bassigny (Troyes). Party per pale, 1st, a demy escarbuncle issuing from the sinister side, 2nd, a bend cotised; on a chief 3 fleurs-de-lis.

Clermont Ferrand (Riom). A fimbriated cross between 4 fleurs-delis.

Cognac (La Rochelle). Francis 1st on horseback, on a chief 3 fleursde-lis.

Colmar (Strasbourg). Per pale gu. and vert, over all a spur rowel.

Compiène (Paris). A liou semy of fleurs-de-lis and crowned.

Coutances (Caen). Three pillars in pale, on a chief a leopard.

Daligre (La Rochelle). No arms found.

Dieppe (Rouen). Per pale gu. and az., a 3-masted ship in full sail, or.

Dijon (Dijon). Gu. a chief parted per pale, 1st, semy of fleurs-de-lis within a bordure compony, 2nd, bendy of six within a bordure.

Dinan (Rennes). A castle of 3 towers, on a chief a row of 5 ermine spots.

Dole (Besançon). Party per fess, in chief a lion issuing out of the base, in base a sun.

Douai (Lille). Gules.

Draguignan (Aix). A wyvern.

Dunkerque (Lille). Party per fess; in chief a lion passant, in base a dolphin.

Etampes (Paris). Three battlemented towers, the middle one charged with an escutcheon bearing, quarterly, 1 and 4 a fleur-de-lis, 2 and 3 a battlemented tower.

Falaise (Caen). A castle of three towers.

Fécamp (Rouen). No arms found.

Fère, La. Barry of six vair and gu.

Fontenay le Comte (Poitiers). A fountain; sometimes between 2 unicorns and with a fleur-de-lis in chief.

Gien (Orleans). A castle with a pointed top, accompanied by two towers also.

Gisors (Rouen). A cross engrailed, on a chief 3 fleurs-de-lis.

Grasse (Aix). A paschal lamb with flag.

Grénoble (Grénoble). Three roses.

Guise (Reims). Semy of fleurs-de-lis, a lion over all on the dexter side. Havre, Le (Rouen). A salamander crowned, on a chief 3 fleurs-de-lis. Another coat is, a ship in full sail.

Joinville (Troyes). Three breys (horses' bits) in fess, on a chief a lion naissant.

Issoire (Riom). A shake-fork, or letter $\mathrm{Y}$, with a stem hooked to dexter. 
Issoudun (Bourges). A shake-fork or letter Y between 3 fleurs-de-lis.

Landrecy (Lille). Three bars couped.

Langheac (Riom). Three pales vair.

Langres (Troyes). A cross saltire between 4 fleurs-de-lis.

Laon (Reims). Three martlets, on a chief 3 fleurs-de-lis.

Laval (Angers). A lion passant guardant (? rampant).

Liesse, Notre Dame de (Reims). No arms found.

Lille (Lille). A fleur-de-lis.

Limoges (Limoges). St. Martial, on a chief 3 fleurs-de-lis.

Lisieux (Caen). Two keys in saltire, on a chief 3 fleurs-de-lis.

Longwy (Metz). Az. a bend arg.

Lons le Saulnier (Besançon). Quarterly, 1, a letter $\mathrm{N}$ under a star ; 2, a bend; 3 , a heart ; 4 , or.

L'Orient (Nantes). A ship sailing over sea, a sun rising behind mountains, a canton ermine, on a chief 3 bezants.

Loudon (Tours). A tower; on a chief 3 fleurs-de-lis.

Lunel (Montpellier). A crescent.

Luģon (Poitiers). Three fishes (pikes) placed fesswise.

Lyon (Lyon). A lion, holding in his right paw a sword, on a chief

3 fleurs-de-lis.

Macon (Dijon). Three annulets, 2 and 1.

Manosque (Aix). Quarterly 1 and 4, a dexter hand, 2 and 3 the same.

Mrns, Le (Tours). A cross and 3 church candlesticks, 2 and 1, a key in pale upon the lower one, on a chief 3 fleurs-de-lis.

Mantes (Paris). Party per pale a fleur-de-lis and a branch of mint, conjoined and dimidiated.

Marennes (La Rochelle). No arms found.

Murseilles (Aix). Arg. a cross az.

Maubeuge (Lille). Quarterly, 4 lions rampant.

Meaux (Paris). Party per pale vert and gu., the Gothic capital letter

$\mathrm{M}$ crowned, a chief semy of fleurs-de-lis.

Melle Poitiers). No arms found.

Melun (Paris). Semy of fleurs-de-lis, a castle triple-towered.

Mende (Montpellier). A sun in splendour in chief, a Gothic capital

letter $\mathrm{M}$ in base.

Metz (Metz). Party per pale, arg. and sa.

Mezières (Reims). Two rakes (râteaux) in chicf, a Roman capital letter

$\mathrm{M}$ in base.

Milhau (Toulouse). Three pales, a chief semy of fleurs-de-lis.

Montargis (Orleans). The Roman capital letter M crowned between

3 fleurs-de-lis, the letters $\mathrm{L}$ and $\mathrm{F}$ in base, one on each side of the $\mathrm{M}$ and

a little below it, the $\mathrm{L}$ on the dexter side.

Montauban (Toulouse). A trunk of a dead tree; on a chief 3 fleursde-lis.

Montpellier (Montpellier). A shield charged with a torteau.

Morlaix (Rennes). A ship on a wave having sails of ermine, and a flag bearing 3 fleurs-de-lis.

Moulins (Riom). Three crosses moline, 2 and 1. 
Nantes (Nantes). A ship with ermine sails; on a chief a line of 7 ermine spots.

Narbonne (Perpignan). A key in pale, wards upwards, and a double cross ranged side by side in fess; on a chief 3 fleurs-de-lis.

Nevers (Bourges). Billety, a lion rampant.

Nimes (Montpellier). A palm tree on a terrace, with a crocodile in fess chained, with the letters COL. NEM.

Niort (Poitiers.) Semy of fleurs-de-lis, a tower with its base in waves.

Noyon (Amiens). Arg. a fess gu.

Orléans (Orléans). Three flint-stones (cailloux) in a heart of fleurs-delis, 2 and 1 ; on a chief 3 fleurs-de-lis.

Parthenay (Poitiers). Barry, a bend engrailed.

Pau. Three stakes or pales united by a fess, on the middle one a peacock in his pride, 2 cows affrontées in base.

Payrat (Toulouse). No arms found.

Perigueux (Bordeaux). A castle of 3 towers, the middle one surmounted by a fleur-de-lis.

Perpignan (Perpignan). Two towers side by side, between them in chief a fleur-de-lis.

Pezenas (Montpellier). Barry, on a canton a porpoise embowed, on a chief 3 fleurs-de-lis.

Poitiers (Poitiers). A lion within a bordure charged with 12 bezants; in a chief 3 fleurs-de-lis.

Pons en Saintonge (La Rochelle). A fess bendy of six, or and gu.

Pontoise (Paris). A bridge of 4 arches supporting a tower having a turret; 2 fleurs-de-lis in chief.

Provins (Paris). A castle of three towers and a central turret surmounted by a fleur-de-lis.

Puy en Velay (Riom). Semy of fleurs-de-lis, an eagle displayed.

Quimper (Nantes). A hart trippant, on a chief 3 fleurs-de-lis.

Reims (Reims). Two branches entwined, a chief semy of fleurs-delis.

Rennes (Rennes). Paly of 6 arg. and sable, on a chief 3 fleurs-de-lis.

Réthel (Reims). Two rakes without handles, one above another.

Riez (Aix). An apple tree with a bear erect, reaching the apples.

Riom (Riom). Two fleurs-de-lis in chief; the Roman capital letter $\mathrm{R}$ in base.

Rochefort (La Rochelle). A rock under a fleur-de-lis in chief.

Rochelle, La (La Rochelle). A ship in full sail; sometimes with a chief of 3 fleurs-de-lis.

Rodez (Toulouse). Three annulets; on a chief 3 fleurs-de-lis.

Rouen (Rouen). A lamb and flag; on a chief 3 fleurs-de-lis.

Sables, Les (Poitiers). No arms found.

Saintes (La Rochelle). A castle with 5 lofty towers, its base in water.

St. Esprit (Montpellier). No arms found.

St. Flour (Riom). Paly gu. and or.

St. Germain-en-Laye (Paris). A child's berceaunette with a fleur-delis in chief and 1638 in base. 
St. Jean d'Angely (La Rochelle). Semy of fleurs-de-lis, a head of John the Baptist in a dish on high stand.

St. Lo (Caen). A unicorn passant; on a chief 3 fleurs-de-lis.

St. Malo (Rennes). A portcullis ; in chief a greyhound courant.

St. Maixent (Poitiers). A crown; on a chief 3 fleurs-de-lis.

St. Martin (La Rochelle). No arms found.

St. Menehould (Reims). Three crescents entwined.

St. Omer (Lille). A double cross (of Lorraine).

St. Quentin (Amiens). A man's head affrontée, behind it 2 batons between three fleurs-de-lis.

Salins (Besançon). Or, a bend gu.

Saumur (Angers). A fess embattled between 3 fleurs-de-lis in chief and the Roman capital letter S in base.

Sedan (Metz). A boar passant under a tree.

Semur en Auxois (Dijon). A tower charged with a shield bendy.

Senlis (Paris). Gu. a pale or.

Sens (Paris). Semy of fleurs-de-lis, a tower.

Soissons (Reims). A fleur-de-lis.

Strasbourg (Strasbourg). Arg. a bend gu.

Turascon (Aix). A castle of 3 towers, beneath it a dragon devouring a man.

Thouars (Poitiers). Three bunches of grapes.

Toul (Metz). A capital letter T.

Toulon (Aix). Or, a cross az., a flag in the first quarter, a chief semy of fleurs-de-lis.

Toulouse (Toulouse). A lamb supporting an upright rod surmounted by a fleur-de-lis, between 2 castles, a chief semy of fleurs-de-lis.

Tours (Tours). Three towers, 2 and 1, on a chief 3 fleurs-de-lis. Another coat is, a tower between 2 fleurs-de-lis, one on each side.

Trévoux (Lyon). A tower; on a chief 3 fleurs-de-lis, each charged with a bend.

Troyes (Troyes). A bend cotised potent and counter potent; on a chief 3 fleurs-de-lis.

Uzes (Montpellier). Bendy, or and gu. Another coat is, three fesses ; on a chief 3 fleurs-de-lis.

Valenciennes (Lille). Party per pale, 1 a lion rampant, 2 a swan. Another coat is, 2 lions leopardies one abovẽ another.

Valognes (Caen). A lion passant guardant.

Vannes (Nantes). An ermine courant, his head crowned and with a flying scarf or cravat (écharpe) arg. semy of ermine round the neck.

Verdun (Metz). A fleur-de-lis under a royal crown.

Versailles (Paris). Three fleurs-de-lis; on a chief a demi eagle with 2 heads, each crowned.

Vesoul (Besançon). Party per fess, the chief billety, a demy lion issuing out of the fess, in the base a crescent.

Vigan, Le. No arms found.

Vitry-le-Français (Troyes). A salamander crowned, in chief two Roman capital letters $\mathrm{F}$, each crowned. 


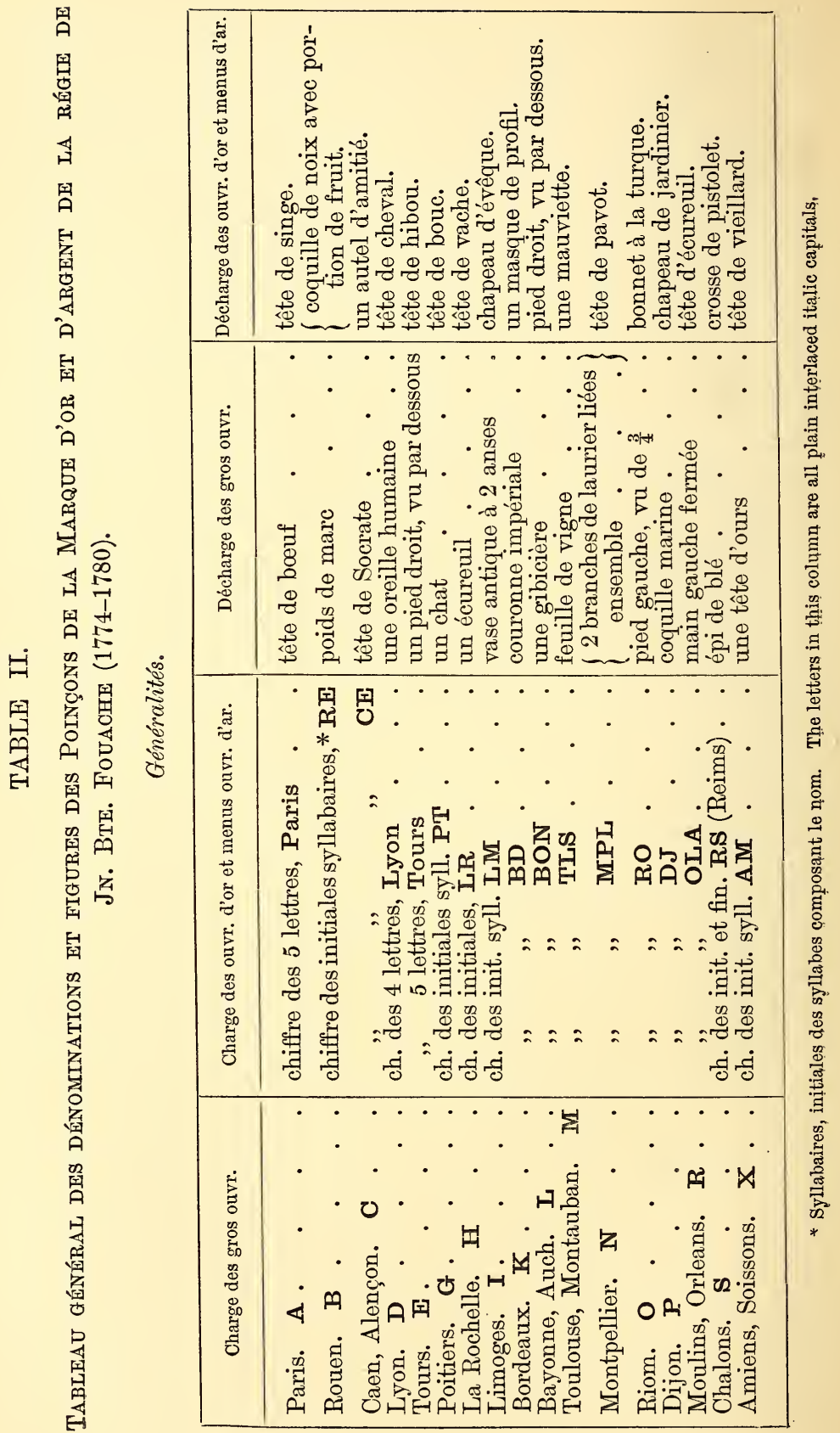


CHAP. III.] PROVINCIAL MARKS USED BY FOUACHE.
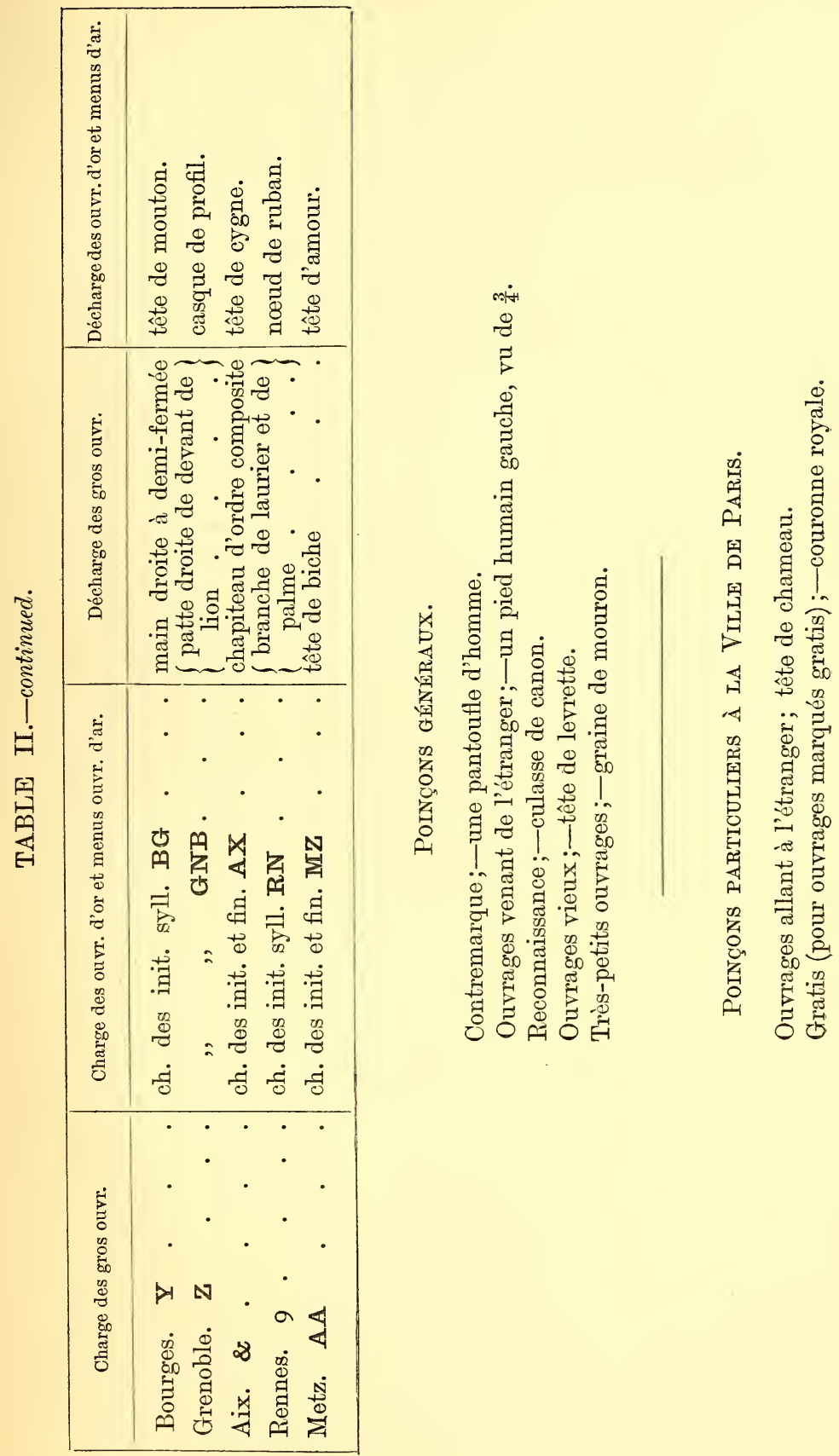


\section{TABLE III.}

Specimens of the Marks of the Charge and Discharge as used in Paris and the three Chief Towns in the Provinces shortly BEFore tHe abolition of aLl TAXes in 1791. (AFter RaIbaUd.)

\begin{tabular}{|c|c|c|c|c|c|c|}
\hline Paris. & $\underset{\begin{array}{c}\mathrm{CH} \\
\text { silver. }\end{array}}{\mathrm{CH}}$ & $\overbrace{\begin{array}{c}\text { Gold and } \\
\text { small } \\
\text { silver. }\end{array}}^{\text {ARGE. }}$ & $\overbrace{\begin{array}{l}\text { Large } \\
\text { silver. }\end{array}}^{\text {Diso }}$ & $\overbrace{\begin{array}{c}\text { Gold and } \\
\text { small } \\
\text { silver. }\end{array}}^{\text {HARGE. }}$ & $\begin{array}{l}\text { Ingots for } \\
\text { drawing. }\end{array}$ & 내을 \\
\hline Lyons. & & & veces & 6. & \multicolumn{2}{|c|}{ Foreign work. } \\
\hline Bordeaux. & & 82 & 鮞 & 5 & Old work. & Ses \\
\hline Rouen. & & De & 중 & (3) & $\begin{array}{l}\text { Very small } \\
\text { wares. }\end{array}$ & 数 \\
\hline
\end{tabular}

These are under H. Clavel, who succeeded J. B. Fouache in 1780. The large letters of the first column are highly ornamented capitals crowned, and those of the second column are of the same fashion but not crowned. These letters are interlaced when the mark is composed of more than one letter, and the letters are not quite the same as those used under J. B. Fouache (see Table II. preceding). Under H. Clavel they are as follows: -Paris, TC linked; Rouen, RV linked; Caen, CA linked; Lyons, L ; Tours, T; Poitiers, P; La Rochelle, LR; Limoges, LG; Bordeaux, B; Bayonne (wanting); Toulouse, TM; Montpellier, MP; Riom, R ; Dijon, D; Moulins, MO ; Chalons, C; Amiens, AS ; Bourges, B; Grenoble, G; Aix, A; Rennes, R; Metz, M. The fashion of the letters is as above.

Of the large discharge marks under Clavel only ten can be given, viz. : tête de satyr; tête de pucelle; tête de cheval; pigeon (probably Paris); grenade; bouquet de pomme (probably Rouen); gantelet; aiguière; pot à l'eau; nœud de rubans (probably Lyons). Of the small discharge marks five are recorded :-nœud de rubans ; tête de dolphin; tête d'enfant; tête de Henri IV.; tête de soldat.

Under the head of Paris, charge and discharge marks are given for St. Germain and Versailles-the former being the letters SG linked; and for the latter the large mark being an ornamented $V$ over two capital LL turned back to back, and for small work a capital $A$ with a $V$ in the form of a branch. This is, in fact, the mark given as for Paris in the small table printed above as Table III.

The mark under Clavel for old work was a lyre (see Table III.). 


\section{TABLE IV.}

A Table of the Maris used by the Communities of Goldsmiths in the Provincial Towns of France from May, 1784, until 1789 (AFter the Plates PUblished in 1786 BX Bernier, Engraver to the MiNT), takeN from "Tratté De LA GaR-

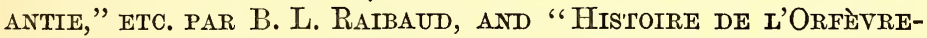
rie," etc., Par Lacroix at Seré.

\begin{tabular}{|c|c|c|c|c|c|}
\hline \multicolumn{2}{|l|}{ MARK. } & \multicolumn{3}{|l|}{ TOWN. } & JURISDICTION OF \\
\hline A bee. & & Abbeville, 1508* & & . & Amiens. $\dagger$ \\
\hline $\begin{array}{c}\text { The hands of a } \\
\text { clock. }\end{array}$ & \#uscos & Agen, 1775 & . & . & Bordeaux. \\
\hline A wing. & wa & Alais, 1775 . & . & . & Montpellier. \\
\hline A wheatsheaf. & & $\operatorname{Aix}$. & . & . & Aix. \\
\hline A spider. & & Alençon, 1718 & - & . & Caen. \\
\hline A crossbow. & & Amiens, 1727 & $\theta$ & . & Amiens. \\
\hline A battledore. & & Angers . & - & . & Angers. \\
\hline A calf's head. & & Angoulême, 1719 & • & . & Limoges. \\
\hline
\end{tabular}

* The date given is that of the incorporation of the goldsmiths of each place into a regular Community.

† The Mint-letter or poinçon de charge found on any piece of provincial plate will be that of the local centre of jurisdiction, under one or other of which each town was placed. For these letters refer to the preceding Table (p. 64). 


\section{TABLE IV.-continued.}

\begin{tabular}{|c|c|c|c|c|c|}
\hline \multicolumn{2}{|l|}{ MARK. } & \multicolumn{3}{|c|}{ TOwN. } & \multirow{2}{*}{$\begin{array}{l}\text { JURISDICTION OF } \\
\text { Montpellier. }\end{array}$} \\
\hline $\begin{array}{l}\text { A hand-brush or } \\
\text { sprinkler. }\end{array}$ & & Annonay & - & • & \\
\hline A pair of scales. & & Apt . & & - & Aix. \\
\hline A crozier head. & & Arles . & . & . & Aix. \\
\hline A chair. & & Arras, 15- & & • & Lille. \\
\hline A cow's head. & & Avalon, 1743 & . & . & Dijon. \\
\hline A shovel. & & Avesnes, 1773 & • & . & Lille. \\
\hline A jackboot. & & Aurillac & . & • & Riom. \\
\hline A buckle. & & Autun, 1784 & • & . & Dijon. \\
\hline A flat candlestick. & & Auxerre, 1731 & . & . & Paris. \\
\hline $\begin{array}{l}\text { A compass card in } \\
\text { flat square case. }\end{array}$ & $\Leftrightarrow$ & Bailleul, 1731 & & • & Lille. \\
\hline $\begin{array}{l}\text { A fish and a } \\
\text { flower. }\end{array}$ & 政 & Bar-le-Duc*. & . & - & Nancy. \\
\hline $\begin{array}{l}\text { A heraldic } \\
\text { maunche. }\end{array}$ & & Bar-sur-Aube, & 763 & - & Troyes. \\
\hline
\end{tabular}

* The goldsmiths of Bar-le-Duc used 2 marks:-1. For Paris standard, two barbels back to back, crowned. 2. For Lorraine standard, 3 pansies, 2 and 1 , crowned.-Lacroix. 
TABLE IV.-continued.

\begin{tabular}{|c|c|c|c|}
\hline \multicolumn{2}{|l|}{ MARK. } & Tows. & JURISDICTION OF \\
\hline A birdcage. & & Bayonne,* 1512 . & Bayonne. \\
\hline A cafetière. & & Beaucaire, 1776 & Montpellier. \\
\hline A wine-glass. & & Beaune, 1742 & Dijon. \\
\hline A fish. & s & Beauvais, 1609 . & Paris. \\
\hline A seal. & 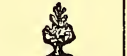 & Bergues St. Vinox, 1750 & Lille. \\
\hline A corkscrew. & & Besançon, $\uparrow 1688$. & Besançon. \\
\hline A trumpet. & $\Rightarrow$ & Béziers, 1598 & Montpellier. \\
\hline $\begin{array}{l}\text { A two-handled vase } \\
\text { with cover. }\end{array}$ & 䆓 & Blois, 1567 . & Orléans. \\
\hline An unicorn. & 海行 & Bordeaux, 12- & Bordeaux. \\
\hline A sailor's hat. & 쇼숭 & $\begin{array}{l}\text { Boulogne - sur - Mer et } \\
\text { Montreuil, } 1744\end{array}$ & Amiens. \\
\hline $\begin{array}{l}\text { A double chain } \\
\text { with tassel end. }\end{array}$ & & Bourg-en-Bresse, 1747 . & Dijon. \\
\hline $\begin{array}{l}\text { A horned sheep's } \\
\text { head. }\end{array}$ & ก次 & Bourges, 1557 & Bourges. \\
\hline
\end{tabular}

* For a second mark, the town arms.-Lacroix.

* An additional mark de reconnaissance was used here of $2 \mathrm{C}$ 's back to back, $\mathrm{OC}$, surmounted by a fleur-de-lis.-Lacroix. 
TABLE IV.-continued.

\begin{tabular}{|c|c|c|c|}
\hline \multicolumn{2}{|l|}{ MARK. } & тоwм. & JURISDICTION OE \\
\hline A great ship. & 角的 & $\begin{array}{l}\text { Brest, Tesneven Lander- } \\
\text { neau, } 169 j\end{array}$ & Rennes. \\
\hline A ploughshare. & & Caen, 1594 & Caen. \\
\hline A hound sejant. & & Cahors, 1777 . & Toulouse. \\
\hline A spur. & & Calais, 1748 & Amiens. \\
\hline A horse's head. & & Cambrai, 1315 & Lille. \\
\hline $\begin{array}{l}\text { A ciborium or } \\
\text { covered cup. }\end{array}$ & & Carcassonne, 1676 & Perpignan. \\
\hline A small bell. & 䟉 & Castres, 1749 . & Perpignan. \\
\hline $\begin{array}{l}\text { A leopard or } \\
\text { lioness passant. }\end{array}$ & 42 & Cau de bec . . & Rouen. \\
\hline A key. & & Chalons-sur-Saone, 1682 & Dijon. \\
\hline A watch-key. & 妈 & Chalons-sur-Marne,1749 & Reims. \\
\hline A bird soaring. & 20 & Chartres, $15-$ & Paris. \\
\hline $\begin{array}{l}\text { A pair of com- } \\
\text { passes. }\end{array}$ & S & Chateau Gonthier, 1757 & Angers. \\
\hline A cock. & $\sqrt{2}$ & Chateau Thierry & Reims. \\
\hline
\end{tabular}


CHAP. III.] PROVINCIAL TOWN MARKS, 1783-89.

TABLE IV.-continued.

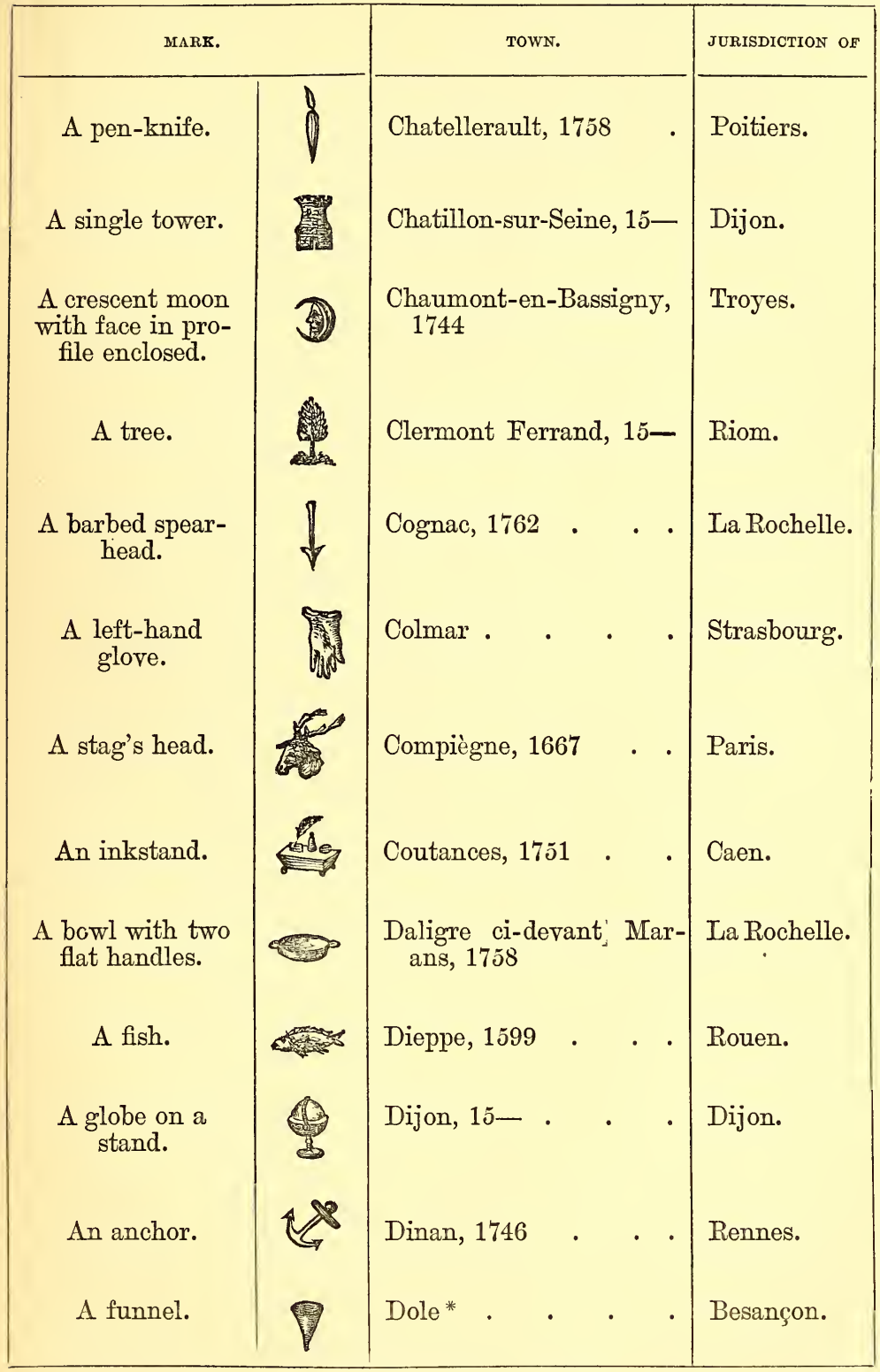

* Also 2 C's back to back, OC, surmounted by a ducal coronet, cf. Besançon.Lacroix. 
TABLE IV.-continued.

\begin{tabular}{|c|c|c|c|c|}
\hline \multicolumn{2}{|l|}{ MARK. } & \multicolumn{2}{|l|}{ TOWN. } & JURISDICTION OF \\
\hline $\begin{array}{c}\text { A . . . . . with } \\
\text { crown above and } \\
\text { crossed branches } \\
\text { below. }\end{array}$ & 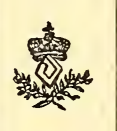 & Douai · & & Lille. \\
\hline An ear of wheat. & & Draguignan, 1751 . & . & Aix. \\
\hline A ragged branch. & & Dunkerque, 1753 & . . & Lille. \\
\hline A crayfish. & $\rightarrow$ & Etampes & . & Paris. \\
\hline A lancet. & & Falaise, 1750 & . & Caen. \\
\hline A stirrup. & & Fécamp, $174 j$ & . & Rouen. \\
\hline A torch. & & Fontenay-le-Comte, & 1571 & Poitiers. \\
\hline An arrow. & & Gien, 1757 & . . & Orléans. \\
\hline A sprig of yew. & 㴽 & Gisors, 1754 . & . & Rouen. \\
\hline A fork. & & Grasse & - . & Aix. \\
\hline A dolphin. & 㷎 & Grenoble & & Grenoble. \\
\hline $\begin{array}{c}\text { The head of a pole } \\
\text { or staff. }\end{array}$ & 竞 & Guise and Vervins, & 1743 & Reims. \\
\hline $\begin{array}{l}\text { A lance with a } \\
\text { pennon. }\end{array}$ & & Havre, Le, 15- & . . & Rouen. \\
\hline
\end{tabular}


CHAP. III.] PROVINCIAL TOWN MARKS, 1783-\$9.

TABLE IV.-continued.

\begin{tabular}{|c|c|c|c|c|}
\hline \multicolumn{2}{|l|}{ MARK. } & \multicolumn{2}{|l|}{ Tows. } & JURISDICTION OF \\
\hline $\begin{array}{l}\text { A staff with small } \\
\text { flag, or guidon. }\end{array}$ & 3 & Joinville, 1757 & . & Troyes. \\
\hline $\begin{array}{c}\text { An oak sprig with } \\
\text { acorn. }\end{array}$ & & Issoire, 1766 & . . & Riom. \\
\hline A goblet. & 1 & Issoudun, $17 \tilde{7}$ & & Bourges. \\
\hline $\begin{array}{l}\text { A holy-water } \\
\text { sprinkler. }\end{array}$ & & La Charité, 1757 & . . & Bourges. \\
\hline A pink. & & La Fère. & . & Reims. \\
\hline A scalpel. & & Landrecy, 1779 . & . . & Lille. \\
\hline A rule or level. & $\infty$ & Langheac, 1784 & . & Riom. \\
\hline $\begin{array}{l}\text { A clasp-knife } \\
\text { open. }\end{array}$ & & Langres, 1566 & . . & Troyes. \\
\hline $\begin{array}{l}\text { A prickly arti- } \\
\text { choke. }\end{array}$ & 2 & Laon & . & Reims. \\
\hline A griffin rampant. & 政 & La Rochelle, 1698 & . . & La Rochelle. \\
\hline A frog. & 5 & Laval . & & Angers. \\
\hline A gridiron. & $\Rightarrow$ & Le Vigan, 1775. & . & Montpellier. \\
\hline A hatchet. & & $\begin{array}{l}\text { Liesse, Notre Dame } \\
1749\end{array}$ & de, & Reims. \\
\hline
\end{tabular}




\section{TABLE IV.-continued.}

\begin{tabular}{|c|c|c|c|c|c|c|}
\hline \multicolumn{2}{|l|}{ MARK. } & \multicolumn{4}{|c|}{ Town. } & JURISDICTION OF \\
\hline A flying-bird. & Nin & Lille . & & . & • & Lille. " \\
\hline $\begin{array}{c}\text { A peasant's wood- } \\
\text { basket. }\end{array}$ & & Limoges, 1719 & · & - & . & Limoges. \\
\hline A cornucopia. & & Lisieux, 1750 & & - & . & Caen. \\
\hline An heraldic label. & $\Delta \Delta \Delta$ & Longwy . & . & . & . & Metz. \\
\hline A Roman lamp. & & Lons-le-Saulni & er, & 1780 & - & Besançon. \\
\hline $\begin{array}{l}\text { A five-pointed star } \\
\text { with three flames } \\
\text { issuing from it. }\end{array}$ & & Lorient, 1745 & & . & • & Nantes. \\
\hline A lantern. & & Loudun, 1646 & . & . & . & Tours. \\
\hline A pine cone. & & Lunel, 1775 . & & - & . & Montpellier. \\
\hline A shuttle. & $\Phi$ & $\begin{array}{l}\text { Luçon, } 1758 \\
\text { Lunéville.* }\end{array}$ & · & 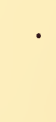 & . & Poitiers. \\
\hline A lion's head. & & Lyon & . & - & • & Lyon. \\
\hline $\begin{array}{c}\text { An open right } \\
\text { hand. }\end{array}$ & Ints & Macon, 1600 . & & - & - & Dijon. \\
\hline
\end{tabular}

* For Paris standard, a letter C crowned. For Lorraine standard, a letter C crowned, but in the middle of it a cross of Lorraine. The goldsmiths of this place and its dependencies used the two initial letters of their name, and a particular device for the town they lived in-e.g., for Lunéville, a crescent; for Charmes, a greyhound ; for Epinal, a star ; for Rembervillers, a letter $R$; and for Saint Diez, a rose.-Lacroix. 
CHAP. III.] PROVINCIAL TOWN MARKS, 1783-89.

TABLE IV.-continued.

\begin{tabular}{|c|c|c|c|c|}
\hline \multicolumn{2}{|l|}{ MARK. } & \multicolumn{2}{|l|}{ Town. } & \multirow{2}{*}{$\begin{array}{l}\text { JURISDICTION OF } \\
\text { Aix. }\end{array}$} \\
\hline A closed book. & 10 & Manosque . & - . & \\
\hline A tulip flower. & of & Mans, Le, 1757 & · & Tours. \\
\hline $\begin{array}{l}\text { A mascle, the } \\
\text { piercing invected. }\end{array}$ & (2) & Mantes . & . . & Paris. \\
\hline An oyster. & & Marennes, 1777 & . & La Rochelle. \\
\hline $\begin{array}{l}\text { A riband tied in } \\
\text { a bow. }\end{array}$ & 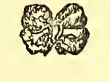 & Marseilles, 12- & . & Aix. \\
\hline An eye. & e & Maubeuge . & . & Lille. \\
\hline A cat sitting. & 2 & Méaux & . . & Paris. \\
\hline A left ear. & ( & Melle . & . & Poitiers. \\
\hline An eel. & $a$ & Melun, 1727 . & . & Paris. \\
\hline A butterfly. & 解 & Mende, 1757 & . & Montpellier. \\
\hline A cannon. & 2 & Mézières, 1746 . & . & Reims. \\
\hline $\begin{array}{l}\text { A peacock in his } \\
\text { pride. }\end{array}$ & 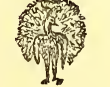 & Metz, $163 \check{~}$ & - & Metz. \\
\hline A fritillary flower. & 6. & Milhau, 1770 . & . & Toulouse. \\
\hline
\end{tabular}


TABLE IV.-continued.

\begin{tabular}{|c|c|c|c|c|}
\hline \multicolumn{2}{|l|}{ MARK. } & \multicolumn{2}{|l|}{ Tows. } & JURISDICTION OF \\
\hline A comb. & Finm & Montargis, 1737 & . & Orléans. \\
\hline A steel-yard. & og & Montauban, $170 \tilde{}$ & & Toulouse. \\
\hline A still. & & Montpellier & . . & Montpellier. \\
\hline A square column. & & Morlaix, 1607 & • & Rennes. \\
\hline $\begin{array}{l}\text { The sails of a } \\
\text { windmill. }\end{array}$ & & Moulins, 1736 & .. & Riom. \\
\hline . . . . . & . & Nancy* & 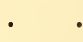 & Nancy. \\
\hline A tilting spear. & & Nantes, 1579 & . . & Nantes. \\
\hline A tobacco-pipe. & 2 & Narbonne, 1669 & • & Perpignan. \\
\hline A wine-bottle. & & Nevers, 1757 & . & Bourges. \\
\hline A porcupine. & & Nimes, 1586 & . & Montpellier. \\
\hline
\end{tabular}

* Two standards used here :--1. Paris, marked with an A under an eagle crowned. 2. Lorraine, marked with the letter A under a cross of Lorraine. The goldsmiths of this community and its dependencies used the two initial letters of their names added to a special device for the town they lived in, as follows :-For Nancy, a thistle ; for Briey, a B ; for Commercy, a crown of roses ; for Etain, a pitcher ; for Mirecourt, an ermine ; for Neuf-château, a tower ; for Pont-à-Mousson, a heart ; for St. Mihiel, a balance ; for St. Nicholas, a spur-rowel ; for Vezelize, a lozenge ; for Bouquenom, a goat; for Dieuze, an ear of wheat; for Forbach, a pine cone; for St. Avold, a pigeon; and for Sarreguemines, an acorn. - Lacroix. 
TABLE IV.-continued.

\begin{tabular}{|c|c|c|c|}
\hline \multicolumn{2}{|l|}{ MARK. } & rows. & JURISDICTION OF \\
\hline $\begin{array}{l}\text { A pot with one } \\
\text { handle on three } \\
\text { small feet. }\end{array}$ & 部 & Niort, 15- . . & Poitiers. \\
\hline $\begin{array}{l}\text { A shallow oval } \\
\text { pan or saltcellar. }\end{array}$ & S2: & Noyon, 1748 . & Amiens. \\
\hline $\begin{array}{l}\text { A Joan of Arc } \\
\text { head with head- } \\
\text { dress of feathers. }\end{array}$ & & Orléans, 1611 & Orléans. \\
\hline Letter P crowned. & & Paris, 1260 & Paris. \\
\hline A skate fish. & & Parthenay, $174 \check{~}$ & Poitiers. \\
\hline A cow. & & Pau & Pau. \\
\hline $\begin{array}{l}\text { A pear with a leaf } \\
\text { attached. }\end{array}$ & & $\begin{array}{l}\text { Payrat, Ste. Colombe et } \\
\text { Chalabre, 1753 }\end{array}$ & Toulouse. \\
\hline A snail. & & Perigueux & Bordeaux. \\
\hline A rat. & 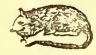 & Perpignan & Perpignan. \\
\hline A garden rake. & & Pézénas, 1586 & Montpellier. \\
\hline $\begin{array}{l}\text { An Eastern cap } \\
\text { with upright } \\
\text { feather and jewel. }\end{array}$ & 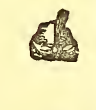 & Poitiers . & Poitiers. \\
\hline A beehive. & i & Pons-en-Saintonge, 1785 & La Rochelle. \\
\hline A clove pink & V & Pontoise, 1752 & Paris. \\
\hline
\end{tabular}


TABLE IV.-continued.

\begin{tabular}{|c|c|c|c|c|}
\hline \multicolumn{2}{|l|}{ MARK. } & \multicolumn{2}{|l|}{ тоwм. } & JURISDICTION OF \\
\hline A moss-rose. & de & Provins, 1759 & . & Paris. \\
\hline $\begin{array}{l}\text { A pulley and } \\
\text { rope. }\end{array}$ & & Puy-en-Telay, 1367 & . & Riom. \\
\hline A frame saw. & $=$ & Quimper, 1780 & . & Nantes. \\
\hline $\begin{array}{l}\text { A bunch of } \\
\text { grapes. }\end{array}$ & & Reims, 1560 & . & Reims. \\
\hline A monkey sejant. & & Rennes, 1579 & . & Rennes. \\
\hline $\begin{array}{l}\text { A quiver of } \\
\text { arrows. }\end{array}$ & & Réthel, 1660 & . & Reims. \\
\hline $\begin{array}{l}\text { A saucer with } \\
\text { one handle. }\end{array}$ & 0 & Riez . & . & Aix. \\
\hline $\begin{array}{l}\text { A cross moline } \\
\text { with an annulet. }\end{array}$ & $\stackrel{2}{7}$ & Riom & . & Riom. \\
\hline A rock. & 6 & Rochefort, 1713 & & La Rochelle. \\
\hline $\begin{array}{l}\text { An urn or vase } \\
\text { and RODEZ. }\end{array}$ & 䡒 & Rodez, 1777 & & Toulouse. \\
\hline $\begin{array}{l}\text { A branch with } \\
\text { cluster of apples. }\end{array}$ & 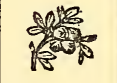 & Rouen, 13- & & Rouen. \\
\hline A sheep passant. & 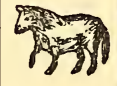 & Sables, Les, 168-- & . & Poitiers. \\
\hline A spring clasp. & 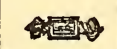 & Saintes, 1758. & & La Rochelle. \\
\hline
\end{tabular}


TABLE IV.-continued.

\begin{tabular}{|c|c|c|c|}
\hline \multicolumn{2}{|l|}{ MARK. } & тошм. & JURISDICTION OF \\
\hline A magpie. & & $\begin{array}{l}\text { St. Esprit et Bagnols, } \\
1777\end{array}$ & Montpellier. \\
\hline A squirrel sejant. & & St. Flour, 1785 . & Riom. \\
\hline A necklace. & 5 & St. Germain-en-Laye & Paris. \\
\hline $\begin{array}{l}\text { A tooth with three } \\
\text { fangs. }\end{array}$ & 鼠 & St. Jean d'Angely, 1779 & La Rochelle. \\
\hline A knotted club. & & St. Lô . & Caen. \\
\hline A hammer. & $\alpha$ & St. Malo, 168- & Rennes. \\
\hline A fly. & 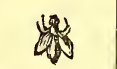 & St. Meixent & Poitiers. \\
\hline A pair of snuffers. & 20 & St. Martin, 1785 & La Rochelle. \\
\hline A watering-pot. & ? & St. Menehould, 1742 & Reims. \\
\hline A dog passant. & हो & St. Omer & Lille. \\
\hline A sword hilt. & & $\begin{array}{l}\text { St. Quentin et Péronne, } \\
1748\end{array}$ & Amiens. \\
\hline A boar. & $(x)$ & Salins, 1640 . & Besançon. \\
\hline $\begin{array}{l}\text { A helmet cup or } \\
\text { ewer. }\end{array}$ & 触 & Saumur, 1749 & Angers. \\
\hline
\end{tabular}


TABLE IV.-continued.

\begin{tabular}{|c|c|c|c|c|}
\hline \multicolumn{2}{|l|}{ MARK. } & \multicolumn{2}{|l|}{ TOWN. } & JURISDICTION OF \\
\hline $\begin{array}{l}\text { A sun or head } \\
\text { of Apollo in } \\
\text { splendour. }\end{array}$ & & Sedan, 1575 . & . & Metz. \\
\hline A caduceus. & & Semur-en-Auxois, & 1701 & Dijon. \\
\hline A kidney bean. & 8 & Senlis & . . & Paris. \\
\hline $\begin{array}{l}\text { A morion affrontée } \\
\text { with feathers. }\end{array}$ & 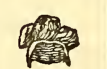 & Sens, $174 j$. & . & Paris. \\
\hline $\begin{array}{l}\text { A helmet affrontée } \\
\text { with vizor closed. }\end{array}$ & 通 & Soissons, 1734 & . . & Reims. \\
\hline A pear. & & Strasbourg & . & Strasbourg. \\
\hline $\begin{array}{l}\text { An open pair of } \\
\text { scissors. }\end{array}$ & & Tarascon . & . & Aix. \\
\hline $\begin{array}{l}\text { A head of Mer- } \\
\text { cury. }\end{array}$ & & Thouars, 1714 & . & Poitiers. \\
\hline A Moor's head. & & Toul, 1643 & . & Metz. \\
\hline An ancient chariot. & & Toulon, 1712 . & . & Aix. \\
\hline A trowel. & & Toulouse, 1500 . & . & Toulouse. \\
\hline A parrot. & & Tours, 1529 & . & Tours. \\
\hline A vine leaf. & 的留 & Trévoux, 1783 . & . & Lyon. \\
\hline
\end{tabular}


CHAP. III.] PROVINCIAL TOWN MARKS, 1783-89.

TABLE IV.-continued.

\begin{tabular}{|c|c|c|c|c|c|}
\hline \multicolumn{2}{|l|}{ MARK. } & \multicolumn{3}{|l|}{ TOWN. } & JURISDICTION OF \\
\hline $\begin{array}{l}\text { A bobbin handle } \\
\text { or short staff. }\end{array}$ & 8 & Troyes, 1369 . & & . & Troyes. \\
\hline A marigold. & 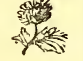 & Valenciennes, 1625 & . & . & Lille. \\
\hline An Apollo's head. & 等 & Valognes, 1750 & . & . & Caen. \\
\hline $\begin{array}{l}\text { An almond pod } \\
\text { split open. }\end{array}$ & 歌 & Vannes, $174 \check{~}$ & • & . & Nantes. \\
\hline A fleur de lys. & 旅 & Verdun, 1630 & - & . & Metz. \\
\hline A wolf's head. & & Versailles, 1768 & · & . & Paris. \\
\hline A double fan. & 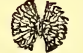 & Vesoul, 1775 & - & . & Besançon. \\
\hline $\begin{array}{l}\text { A head with three- } \\
\text { cornered hat and } \\
\text { pigtail. }\end{array}$ & 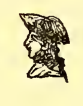 & Vitry-le-Français, & 1614 & & Troyes. \\
\hline
\end{tabular}




\section{CHAPTER IV.}

THE HALL MARKS USED IN PARIS AND THE DEPARTMENTS, SINCE 1797.

The modern hall-marks of $1797,1809,1819$, and 1838 , with tables.

The two preceding Chapters have brought down the history of plate-marking in Paris and the Provinces of France respectively to the year 1789. From that time a period of entire chaos intervenes, until in 1797 the necessary step was taken of starting the craft afresh upon a modern basis. Possibly it was found difficult to get on any longer without taxes.

This new departure was effected by the law of 19 Brumaire, Year VI. (9 Nov. 1797), which is not without some importance, as it is the groundwork of all more modern French and Swiss legislation.

But for this fact and for the necessity of bringing our account of French marks down, somehow or other, to the present day, it would hardly be worth venturing into the bewildering sea of modern French hall-marks, since they are of comparatively little interest to amateur or collector, and of none to the antiquary.

A few words about such features of the law of 1797 as seem of any importance will suffice.

Its first chapter deals with the standards and remedy, which it appoints shall be those detailed on an earlier 
page. It also ordains that the quality of metal shall be for the future reckoned in millièmes.

The second chapter deals with the punches and marks.*

To those of the maker, of the standard, and of the office, it added stamps for ancient and foreign and plated wares, and also a special mark called the poinçon de recense, to be applied by public authority should it be necessary at any time to counteract the effect of any falsifications of standards or punches, by verifying the authenticity of the marks found upon plate. The punches in use up to this time were to be defaced as soon as the new punches were ready to replace them.

The mark of the maker was to consist of the initial letters of his name with a symbol, and was to be of the form and propertions ordained by the administration of the Mint. The Mint authorities in due course (17 Nivôse, an 6, or 6 Jan. 1797-8) prescribed that the maker's mark should be the initials of his name with a symbol in a lozenge. The punch of the standard was to be a cock, with Arabic figures 1, 2, or 3, to denote the various standards. These punches were to be uniform throughout the Republic.

A particular sign or number is added to the punch for each departmental office. A small punch of a cock's head was appointed for small gold wares, and a fasces for small wares of silver.

A punch for old plate alone, called de hazard, represented a hatchet; and plate coming from abroad was marked $\mathrm{E} \mathrm{T}$.

* An entirely new set of marks were provided, which the tables appended to this Chapter sufficiently illustrate. 
It then provided for the care of the punches, for the punishment of those who made false punches, and for the destruction of the punches previously in use.

The third chapter levied a duty on gold and silver wares, whether made in France or imported, the usual exceptions being made in favour of the plate of ambassadors, and of a small quantity (5 hectogrammes) for travellers' personal use.

Other chapters then provide for the suppression of the Common Halls of Goldsmiths, the regulation of the Assay Offices and the functions of their officers; after which the obligations of makers are dealt with.

Goldsmiths were to enter their punches with the proper administrations, who were to strike them upon a copper plate kept for the purpose; they were to keep a detailed register of articles sold, and to particularise in the account rendered to customers the kind, standard, and weight of the articles, distinguishing between new and old wares.

These are all the provisions that are of any moment to us.

A few words need be added about the gratuitous recense, or verification, that accompanied the changes in the marks from time to time.

These took place in $1797,1809,1819$, and lastly 1838 , besides one for watches alone, in 1822. On the first occasion makers and merchants were bound, within six months after the publication of the law (Nov. 1797), to carry to the Assay Office of their district their new works of gold, silver, and silver gilt, marked with the old punches, to be marked with the punch of verification to be appointed by the Administration of the Mint. This verification of the old punches was to be done with- 
out charge for six months, but objects submitted after the expiration of that time were to be assayed and the assay dues charged.

Other unsold works, not bearing the stamp of the poinçon de charge, were also to be brought in and stamped with the standard and assay marks, and assay dues to be paid upon them.

The verification mark was also applied on occasion of each subsequent recense gratis within a certain limit of time, as a counter-mark of verification to the marks of the set of punches whose use ceased on the day of the recense commencing, and it was applied to all wares then exposed for sale. After the limit of grace, all wares for sale marked with the old punches, but not thus verified, were liable to be assayed afresh and to a payment of duty. The marks used on each occasion will be found with the rest in the subjoined tables.

The last recense took place in 1838, and from that time the punches then ordained for the future have remained in use.

The tables of these complicated nineteenth-century marks have been published and are comparatively wellknown.

Those from 1797 to 1838 are given by M. Raibaud in great detail in a work called Traité sur la Garantie des Matières d'Or et d'Argent, published in Paris in 1825, whilst those of 1838 have been printed by Raibaud and also in a little treatise by De Geneste called Nouveau Manuel de la Garantie, etc., published in Paris in 1839. Raibaud was assay master at Marseilles for many years, and De Geneste was contrôleur de la garantie for Paris in the year 1838. With these and other unexceptionable authorities, the following tables have been carefully com pared. Although they are not of much interest to the 
antiquary or the collector of old plate, an account of French plate marks would not be complete without them ; and they are therefore added here to the more interesting and important tables given in the preceding chapters. It is to be regretted that some French authority with better opportunities than those at the disposal of a foreign amateur should not have undertaken for the benefit of his fellow-students a more complete explanation of the mode of dating the beautiful works of the old French goldsmiths than that which was attempted, it is believed for the first time, in the first edition of the present little treatise, which has now been revised, and, it is hoped, rendered more useful to the amateur and collector of Old French Plate.*

\section{SUMMARY OF MODERN MARKS AND EXPLANATION OF THE FOLLOWING TABLES.}

$1797-1809$.

The cock in various attitudes for all the standards, accompanied by numerals to denote the qualities, alike for Paris and Departments. The numeral in the case of the Departments is in a different part of the punch, the attitude of the bird being the same for the same quality both in Paris and the Departments. A different attitude is adopted for each different quality.

The departmental assay mark is the classical head affrontée with the number of the Department.

Plate for sale, but not sold at the date of the commencement of these marks, if already marked with the then existing or older marks, would be countermarked or verified with the head having a Phrygian cap.

1809-1819.

The cock, but in a fresh set of attitudes, for standard; with a lion's head for Paris assay mark, or a hand with departmental number for the Departments, for gold.

* Long since they were printed in the present work they have appeared in France and in America, in the latter case avowedly copied from it. 
The Paris, as well as the departmental marks for silver, are human heads, a number being added on the rim of the punch for the Departments ; for smaller wares there is a different head, with the number on the cap for the Departments.

As before there are verification marks, used as in 1797 .

1819-1838.

Four-footed animals are now appointed for standard, with numerals as before for gold; human heads for silver, as shown in the tables.

For assay and verification, various marks; the assay marks for the Departments being differenced with departmental number as before.

Verification marks used as before in 1797 .

For very small wares of this period, see the table of Divisional Punches, and the long appended list of letters and figures that went with them.

The Bigornes are given on a separate plate. These were small countermarks introduced for the first time in 1819, and were applied in a novel manner, being borne on the surface of the anvil, and appearing, therefore, exactly behind the mark of the punch on the piece of plate under manipulation.

1838 to the present time.

For standard, head of Greek physician for gold, with departmental mark for each Department, as shown on appended table; for silver, head of Minerva, similarly differenced.

For assay, verification, \&c., the various marks shown.

A new mark for gold chains, called the poingon de remarque, was introduced at this time. It should appear at every decimetre of their length. A decimètre is a very little less than four inches.

As before, there were a great variety of Bigorne countermarks; those used in Paris are insects in profile, those of the Departments seen from above in bird's-eye view. It would be useless, if not impossible, to give engravings of them. 
Table of the Punches Made in pursuance of the LaW of 19 Brumatre, Year VI. (9 Nov. 1797), to Replace those of the Communities of Goldsmiths AND OF the Administration of Taxes. Used 9 Nov. 1797-1 SePt. 1809.

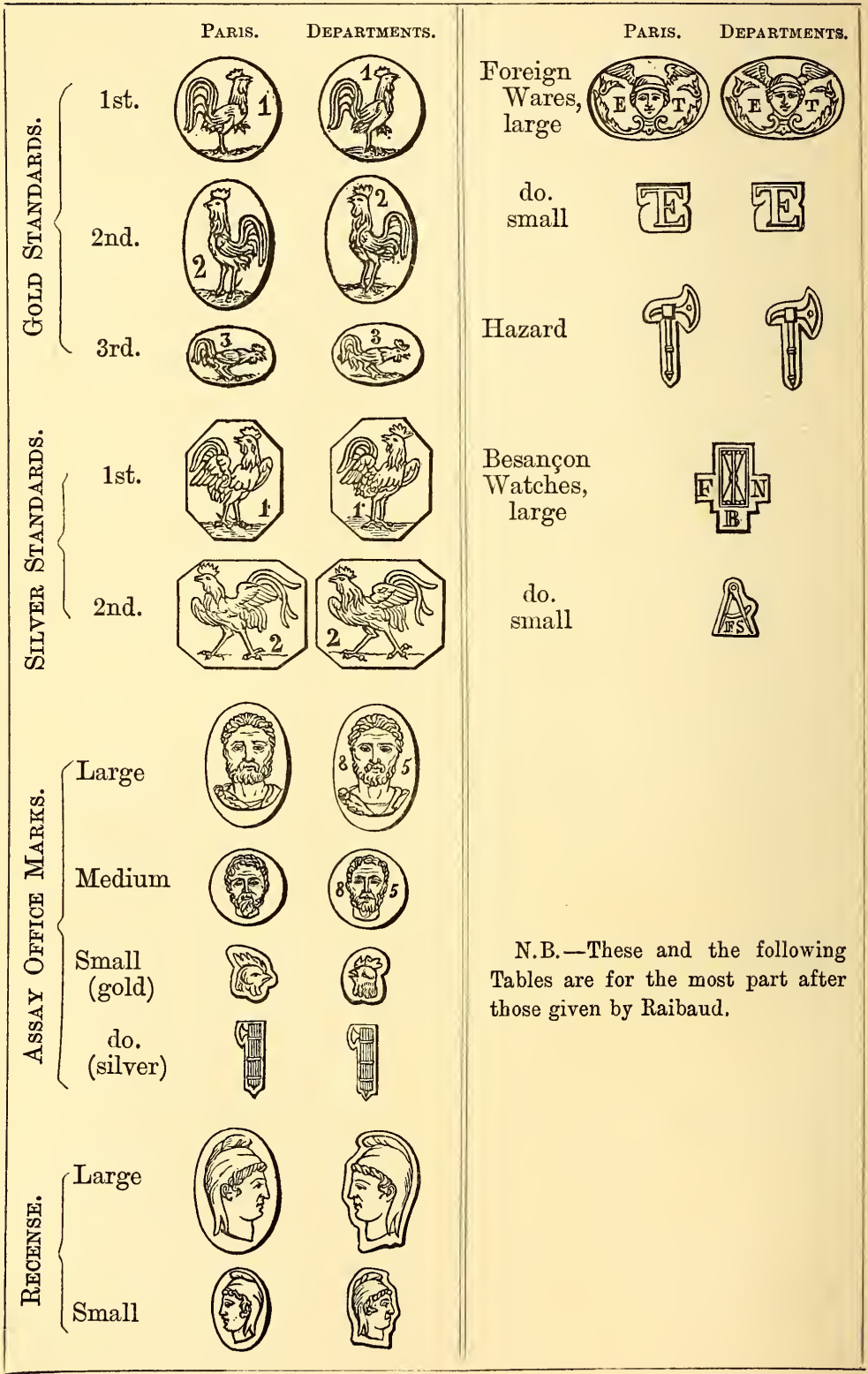


CHAP. IV.]

Table of the Punches made in pursuance of a Decree of 11 Prairial, Year XI. (31 MaY, 1803). Used 1 SePt. 1809-16 AUg. 1819.

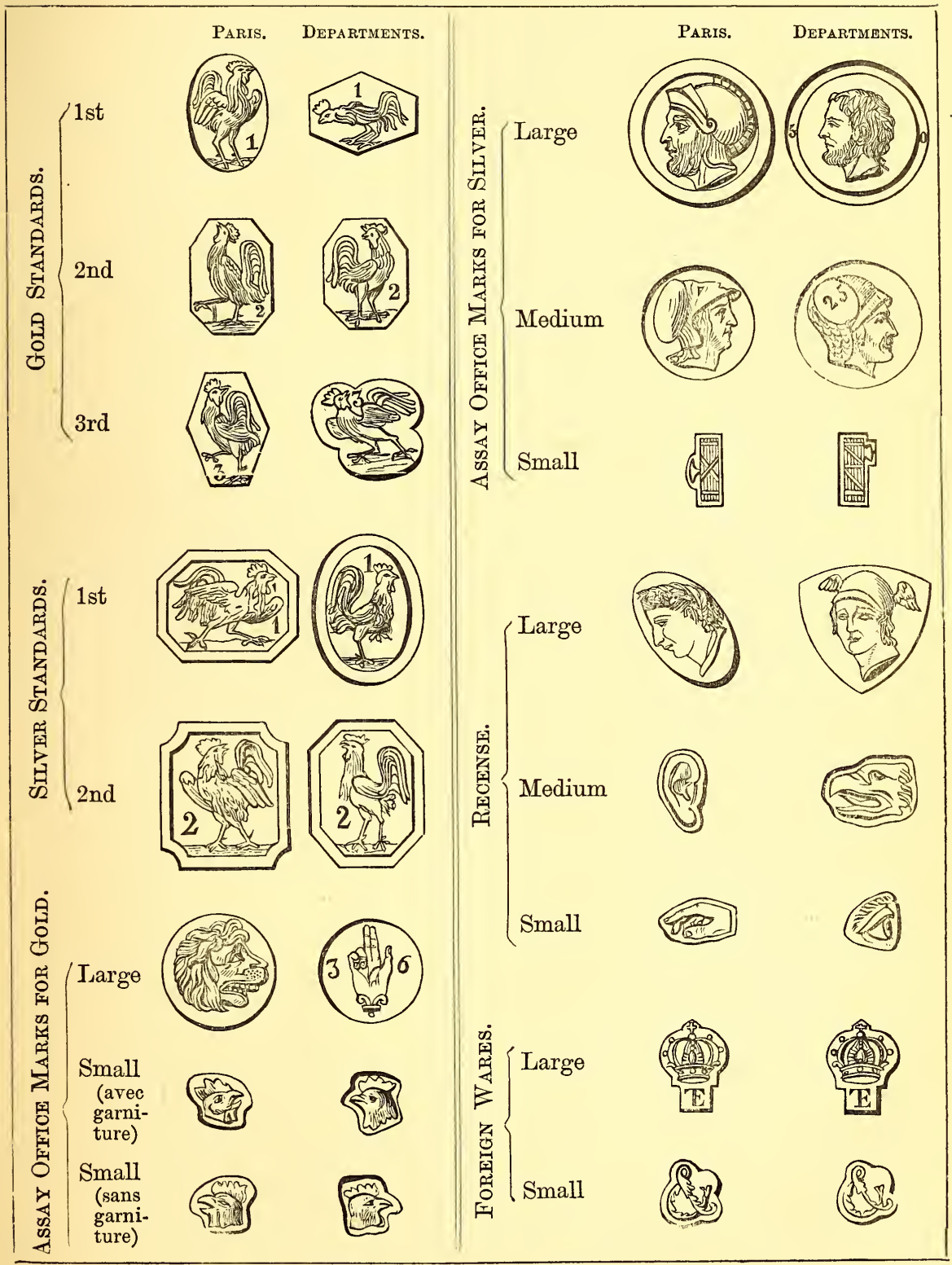


Table of the Punches made in pursuance of a Royal Ordinance of 22 OCT. 1817. UsEd 16 AUg. 1819-10 MAY, 1838.

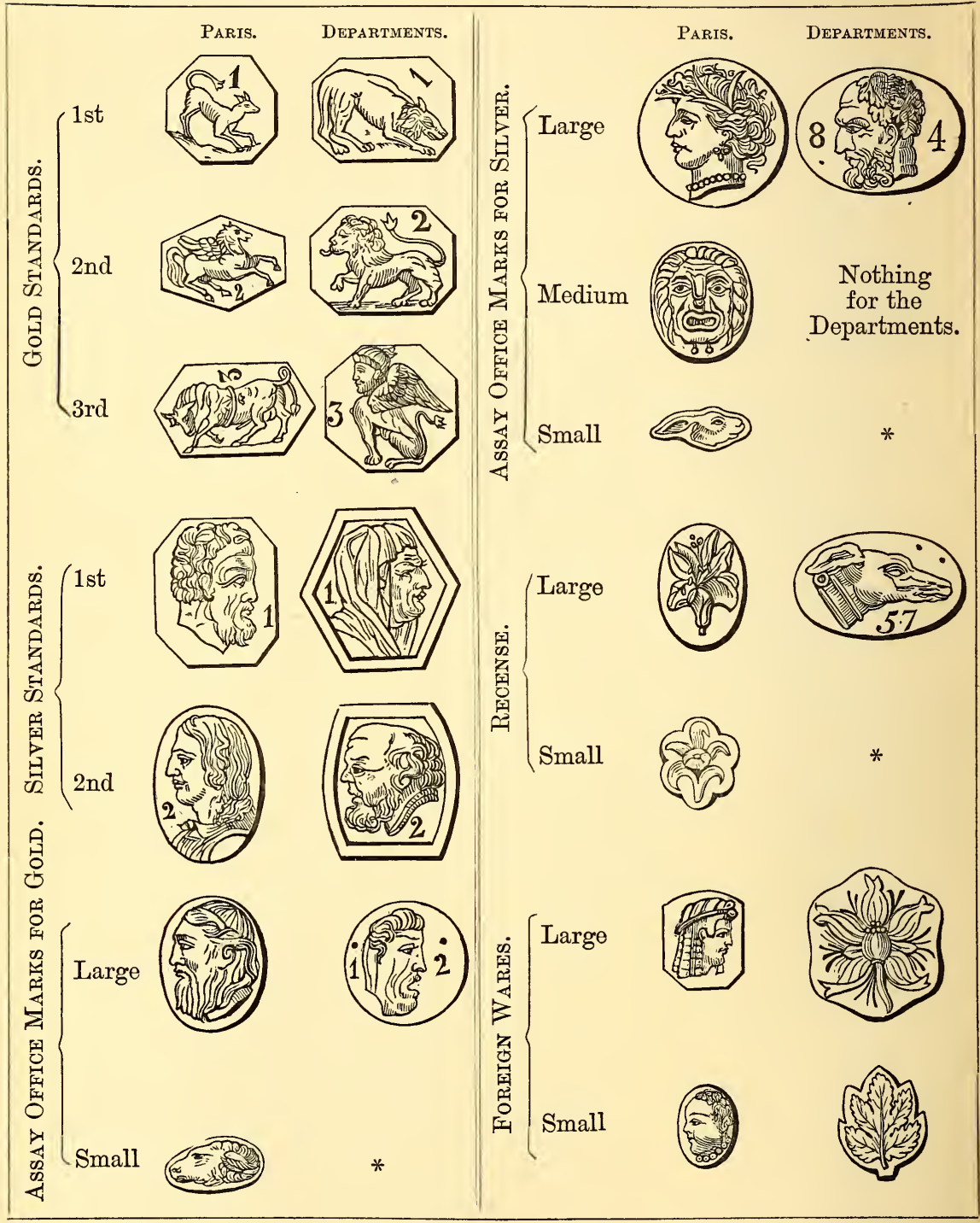

Note (1). - In the figure of the large Assay Office and Recense Marks is engraved the number of the Department, as given in the following list of Assay Offices (p. 93).

(2.) For the marks proper to the spaces marked above with an asterisk, thus *, see the Table of Divisional Punches on the opposite page. 
CHAP. IV.]

Table of Divisional Punches made in pursuance of the Ordinance of 22 OCt. 1817. Used 16 AUg. 1819-10 MaY, 1838.

\begin{tabular}{|c|c|c|c|}
\hline Drvisions. & GoLD. & SILVER. & RECENSE. \\
\hline 1. NоRтн. & Car & Butterfly & $\begin{array}{r}\text { Coffee } \\
\text { Pot }\end{array}$ \\
\hline $\begin{array}{l}\text { 2. NortH- } \\
\text { EAST. }\end{array}$ & $\begin{array}{c}\text { Sword- } \\
\text { hilt }\end{array}$ & Tortoise & Tower \\
\hline 3. EAst. & Tiara & Shell & Ciborium \\
\hline $\begin{array}{l}\text { 4. South- } \\
\text { EAST. }\end{array}$ & Fan & Beetle & Goblet \\
\hline 5. SoutH. & Helmet & Lysse & Bell \\
\hline $\begin{array}{l}\text { 6. South- } \\
\text { WEST. }\end{array}$ & Lyre & Frog & $\begin{array}{l}\text { Watering } \\
\text { Pot }\end{array}$ \\
\hline 7. West. & Morion & Snail & Ewer \\
\hline $\begin{array}{c}\text { 8. NoRTH- } \\
\text { WEST. }\end{array}$ & Trumpet & $\begin{array}{c}\text { Skate- } \\
\text { fish }\end{array}$ & Guitar \\
\hline 9. Centre. & $\begin{array}{l}\text { Fleur-de- } \\
\text { lis }\end{array}$ & $\begin{array}{c}\text { Guinea } \\
\text { Pig }\end{array}$ & Book \\
\hline
\end{tabular}

NoтE. - In the figure of the small Assay Office and Recense Marks for each Division is engraved the characteristic sign indicated in the following Tabular List of Assay Offices (p. 93). 
Table of the Signs which form the Bigorne Marks and CounterMarks made in pURsuance of THE ORdinance of 1 July, 1818. Used 16 AUg. 1819-10 MaY, 1838.

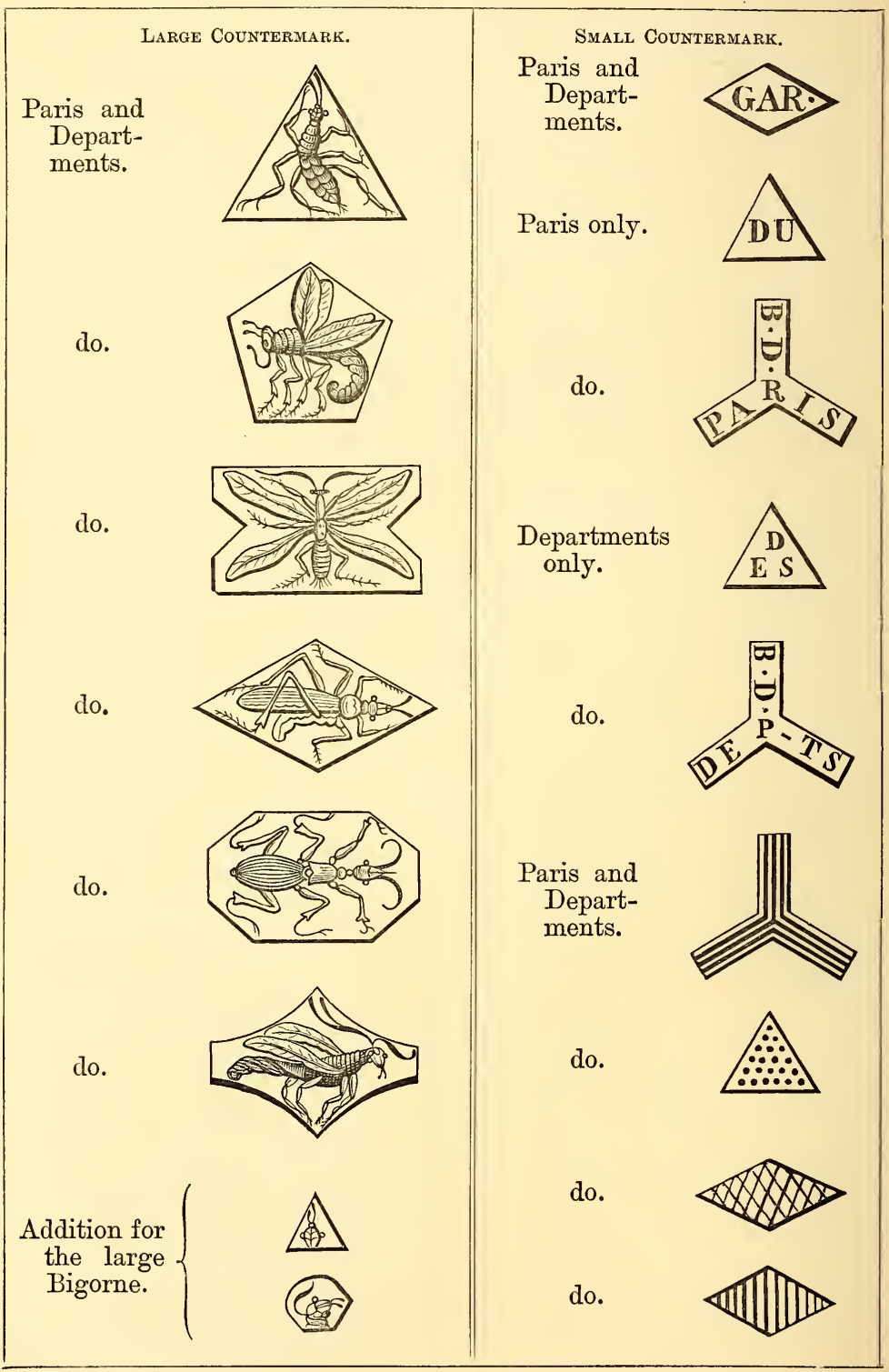


Tabular List of the Assay Offices in the Departments, Divided into Nine Regions, with the Characteristic Signs which Distinguish the Punches OF EACH. Used 16 AUg. 1819-10 MaY, 1838.

\begin{tabular}{|c|c|c|c|c|c|c|}
\hline \multirow{2}{*}{ Divisions. } & \multirow{2}{*}{ Departments. } & & \multirow{2}{*}{\multicolumn{2}{|c|}{ Bureaux. }} & \multicolumn{2}{|c|}{$\begin{array}{l}\text { Characteristic } \\
\text { Signs. }\end{array}$} \\
\hline & & & & & $\begin{array}{l}\text { Large } \\
\text { Work. }\end{array}$ & $\begin{array}{l}\text { Small } \\
\text { Work. }\end{array}$ \\
\hline I. 故 & $\begin{array}{l}\text { Nord } \\
\text { Pas de Calais } \\
\text { Somme. } \\
\text { Aisne . } \\
\text { Seine Inférieure . } \\
\text { Oise . } \\
\text { Eure } \\
\text { Eure et Loir . } \\
\text { Seine et Oise. } \\
\text { Seine et Marne. } \\
\end{array}$ & & 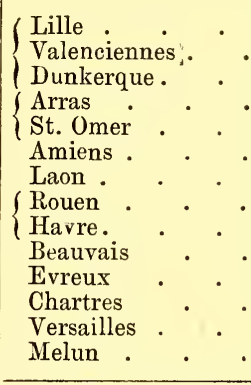 & 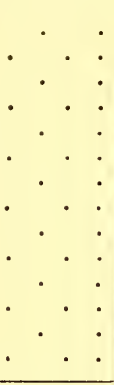 & $\begin{array}{l}57 \\
57^{*} \\
57^{* *} \\
60 \\
60^{*} \\
75 \\
2 \\
73 \\
73 * \\
58 \\
25 \\
26 \\
72 \\
71 \\
\end{array}$ & $\begin{array}{c}\text { A } \\
\text { C } \\
\text { D } \\
\text { E } \\
\text { H } \\
\text { J } \\
\text { I } \\
8 \\
\text { N } \\
\text { T } \\
\text { V } \\
\text { X } \\
\text { Y } \\
\text { W }\end{array}$ \\
\hline 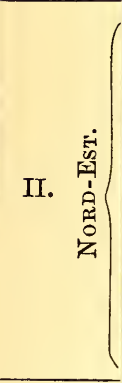 & $\begin{array}{l}\text { Ardennes } \\
\text { Meuse } \\
\text { Moselle . } \\
\text { Rhin (Bas) } \\
\text { Meurthe } \\
\text { Vosges . } \\
\text { Marne . } \\
\text { Marne (Haute). } \\
\text { Aube . } \\
\end{array}$ & & 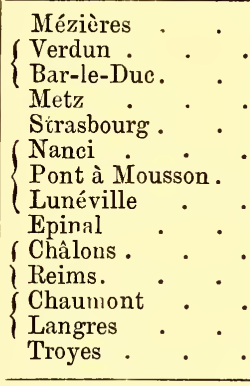 & 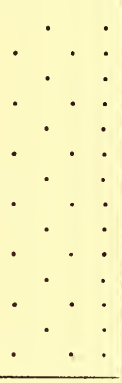 & $\begin{array}{l}7 \\
53 \\
53 * \\
55 \\
65 \\
52 \\
52 * \\
52 * * \\
83 \\
49 \\
49 * \\
50 \\
50 * \\
9\end{array}$ & $\begin{array}{l}\mathrm{A} \\
\mathrm{C} \\
\mathrm{D} \\
\mathrm{E} \\
\mathrm{H} \\
\mathrm{J} \\
\mathrm{M} \\
8 \\
\mathrm{~N} \\
\mathrm{~T} \\
\mathrm{~V} \\
\mathrm{X} \\
\mathrm{Y} \\
\mathrm{W}\end{array}$ \\
\hline III. 点 & $\begin{array}{l}\text { Rhin (Haut) } \\
\text { Saône (Haute) } \\
\text { Doubs } \\
\text { Jura } \\
\text { Côte d'Or. } \\
\text { Saône et Loire } \\
\text { Ain . } \\
\text { Isère . . } \\
\text { Rhône . }\end{array}$ & & $\begin{array}{l}\text { Colmar } \\
\text { Vesoul . } \\
\text { \{esançon } \\
\text { Montbeliard . } \\
\text { Lons-le-Saulnier } \\
\text { Dijon } \\
\text { Macon } \\
\text { Trévoux. } \\
\text { Grenoble } \\
\text { Lyon . }\end{array}$ & 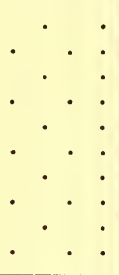 & $\begin{array}{l}66 \\
68 \\
23 \\
23 * \\
37 \\
19 \\
69 \\
1 \\
36 \\
67\end{array}$ & $\begin{array}{c}\mathrm{A} \\
\mathrm{C} \\
\mathrm{D} \\
\mathrm{E} \\
\mathrm{H} \\
\mathrm{J} \\
\mathrm{M} \\
8 \\
\mathrm{~N} \\
\mathrm{~T}\end{array}$ \\
\hline IV. & $\begin{array}{l}\text { Var } \\
\text { Bouches du Rhône } \\
\text { Gard . } \\
\text { Vaucluse . } \\
\text { Alpes (Basses) } \\
\text { Alpes (Hautes). } \\
\text { Drôme . } \\
\text { Ardèche } \\
\text { Loire (Haute) } \\
\text { Loire . }\end{array}$ & & $\left\{\begin{array}{l}\text { Toulon } \\
\text { Grasse } \\
\text { MIarseille } \\
\text { Aix } \\
\text { Arles } \\
\text { Nîmes } \\
\text { Alais } \\
\text { Avignon } \\
\text { Digne. } \\
\text { Gap } \\
\text { Valence } \\
\text { Privas } \\
\text { Le Puy } \\
\text { St. Etienne } \\
.\end{array}\right.$ & 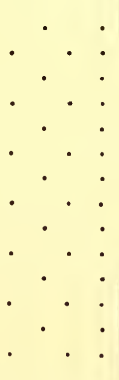 & $\begin{array}{l}78 \\
78 * \\
12 \\
12^{*} \\
12^{* * *} \\
28 \\
28 * \\
79 \\
4 \\
5 \\
24 \\
6 \\
41 \\
40\end{array}$ & $\begin{array}{l}\mathrm{A} \\
\mathrm{C} \\
\mathrm{D} \\
\mathrm{E} \\
\mathrm{H} \\
\mathrm{J} \\
\mathrm{M} \\
8 \\
\mathrm{~N} \\
\mathrm{~T} \\
\mathrm{~V} \\
\mathrm{X} \\
\mathrm{Y} \\
\mathrm{W}\end{array}$ \\
\hline
\end{tabular}


Tabular List of the Assay Offices, etc.-continued.

\begin{tabular}{|c|c|c|c|c|}
\hline \multirow{2}{*}{ Divisions. } & \multirow{2}{*}{ Departments. } & \multirow{2}{*}{ Bureaux. } & \multicolumn{2}{|c|}{$\begin{array}{c}\text { Characteristic } \\
\text { Signs. }\end{array}$} \\
\hline & & & $\begin{array}{l}\text { Large } \\
\text { Work. }\end{array}$ & $\begin{array}{l}\text { Small } \\
\text { Work. }\end{array}$ \\
\hline V. $\begin{array}{c}\text { S } \\
\text { 记 }\end{array}$ & 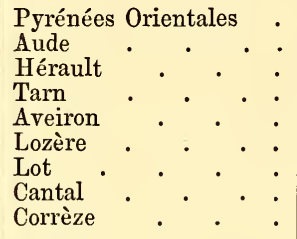 & 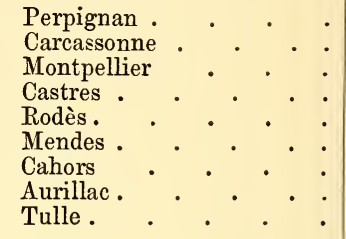 & $\begin{array}{l}64 \\
10 \\
32 \\
76 \\
11 \\
46 \\
44 \\
14 \\
18\end{array}$ & $\begin{array}{l}\mathrm{A} \\
\mathrm{C} \\
\mathrm{D} \\
\mathrm{E} \\
\mathrm{H} \\
\mathrm{J} \\
\mathrm{M} \\
8 \\
\mathrm{~N}\end{array}$ \\
\hline 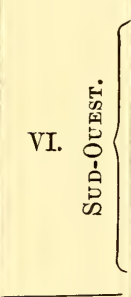 & 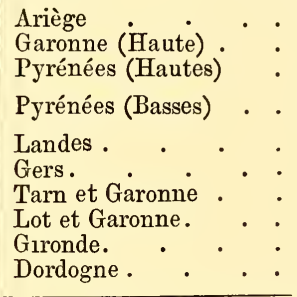 & $\begin{array}{l}\text { Foix } \\
\text { Toulouse } \\
\text { Tarbes . } \\
\begin{array}{l}\text { Pau } \\
\text { Baionne }\end{array} \\
\text { Mont de Marsan. } \\
\text { Auch } \\
\text { Montauban } \\
\text { Agen } \\
\text { Bordeaux . } \\
\text { Périgueux }\end{array}$ & $\begin{array}{l}8 \\
29 \\
63 \\
62 \\
62 * \\
38 \\
30 \\
77 \\
45 \\
31 \\
22\end{array}$ & $\begin{array}{l}\mathrm{A} \\
\mathrm{C} \\
\mathrm{D} \\
\mathrm{E} \\
\mathrm{H} \\
\mathrm{J} \\
\mathrm{M} \\
8 \\
\mathrm{~N} \\
\mathrm{~T} \\
\mathrm{~V}\end{array}$ \\
\hline 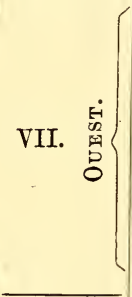 & 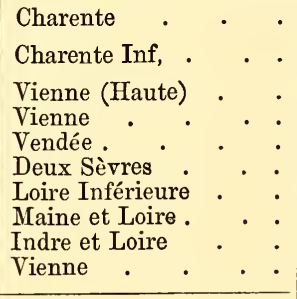 & $\begin{array}{l}\text { Angoulême. } \\
\text { La Rochelle } \\
\text { Saintes } \\
\text { Limoges }\end{array}$ & $\begin{array}{l}15 \\
16 \\
16 * \\
82 \\
81 \\
80 \\
74 \\
42 \\
47 \\
35 \\
\cdots\end{array}$ & $\begin{array}{l}A \\
C \\
D \\
E \\
H \\
J \\
M \\
8 \\
N \\
T \\
\text { W }\end{array}$ \\
\hline 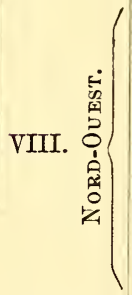 & 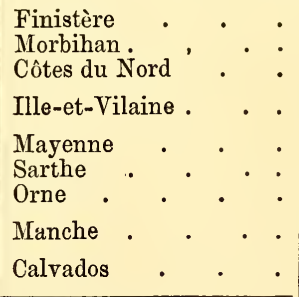 & 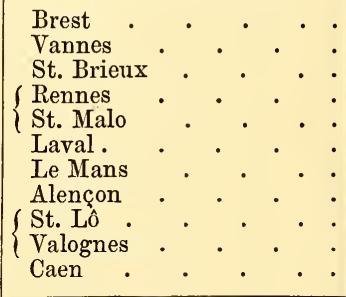 & $\begin{array}{l}27 \\
54 \\
20 \\
33 \\
33 * \\
51 \\
70 \\
59 \\
48 \\
48^{*} \\
13\end{array}$ & $\begin{array}{l}\mathrm{A} \\
\mathrm{C} \\
\mathrm{D} \\
\mathrm{E} \\
\mathrm{H} \\
\mathrm{J} \\
\mathrm{M} \\
8 \\
\mathrm{~N} \\
\mathrm{~T} \\
\mathrm{~V}\end{array}$ \\
\hline 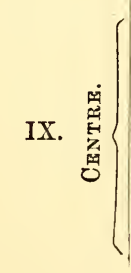 & 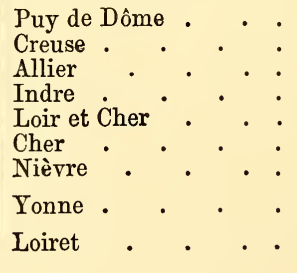 & 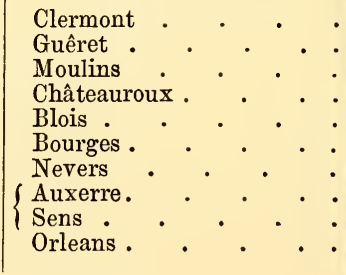 & $\begin{array}{l}61 \\
21 \\
3 \\
34 \\
39 \\
17 \\
56 \\
84 \\
84 * \\
43\end{array}$ & $\begin{array}{l}\mathrm{A} \\
\mathrm{C} \\
\mathrm{D} \\
\mathrm{E} \\
\mathrm{H} \\
\mathrm{J} \\
\mathrm{M} \\
\mathrm{N} \\
\mathrm{T} \\
8\end{array}$ \\
\hline
\end{tabular}


Table of Standard, Assay Office, and Verification Marks for Paris and the Departments, made in pursuance of an OrdiNANCE OF 30 JUNE, 1835. USED FROM 10 MAY, 1838.

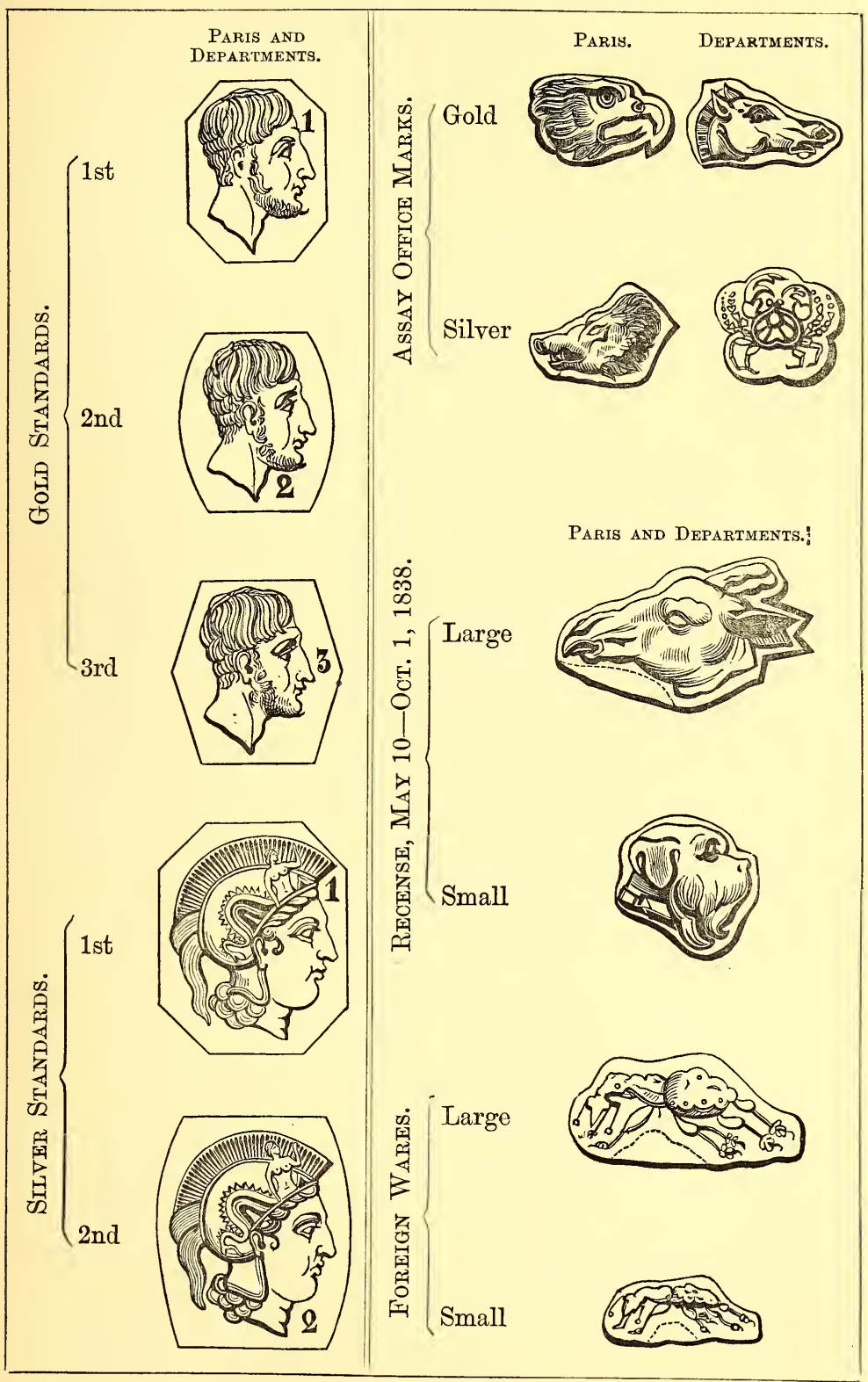


Table of Standard, Assay Office, and Verification Marks, etc. -continued.

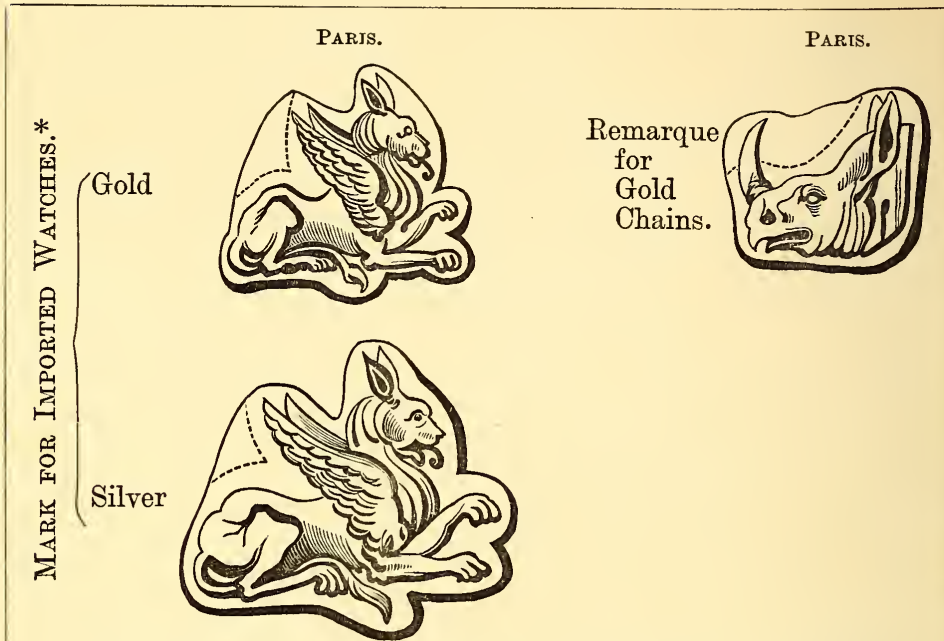

* Used in Paris, Lyons, Besançon, Montbéliard, and Lons-leSaulnier.

Nore.-In the figures of the above marks when used out of Paris the distinctive sign of one or other of the Assay Offices in the Departments would appear. There is no special mark to distinguish the punches used in Paris.

Spectal Marks for Watches made in pUrsuance of aN ORdinance of 19 SePt. 1821.
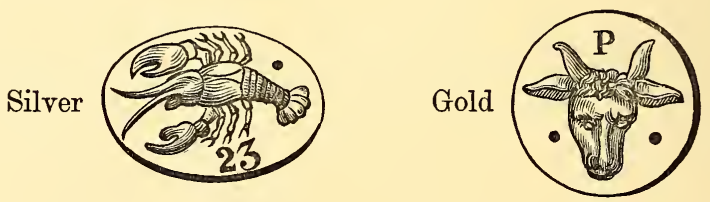

Note. -The letter $\mathrm{P}$ signifies the Paris Office. The Departments had the number indicated for them in the Table (see p. 93) in use from 1819-1838. 
Alphabetical List of the Departments, showing all the Assay Offices throvghout France, and the Characteristic Signs Which distinguish the Standard and Assay Office Punches in each place. Used from 10 MAY, 1838, IN CONJUNCTION WITH THE MARKS ON THE LAST PRECEDING TABLE (SEE P. 95).

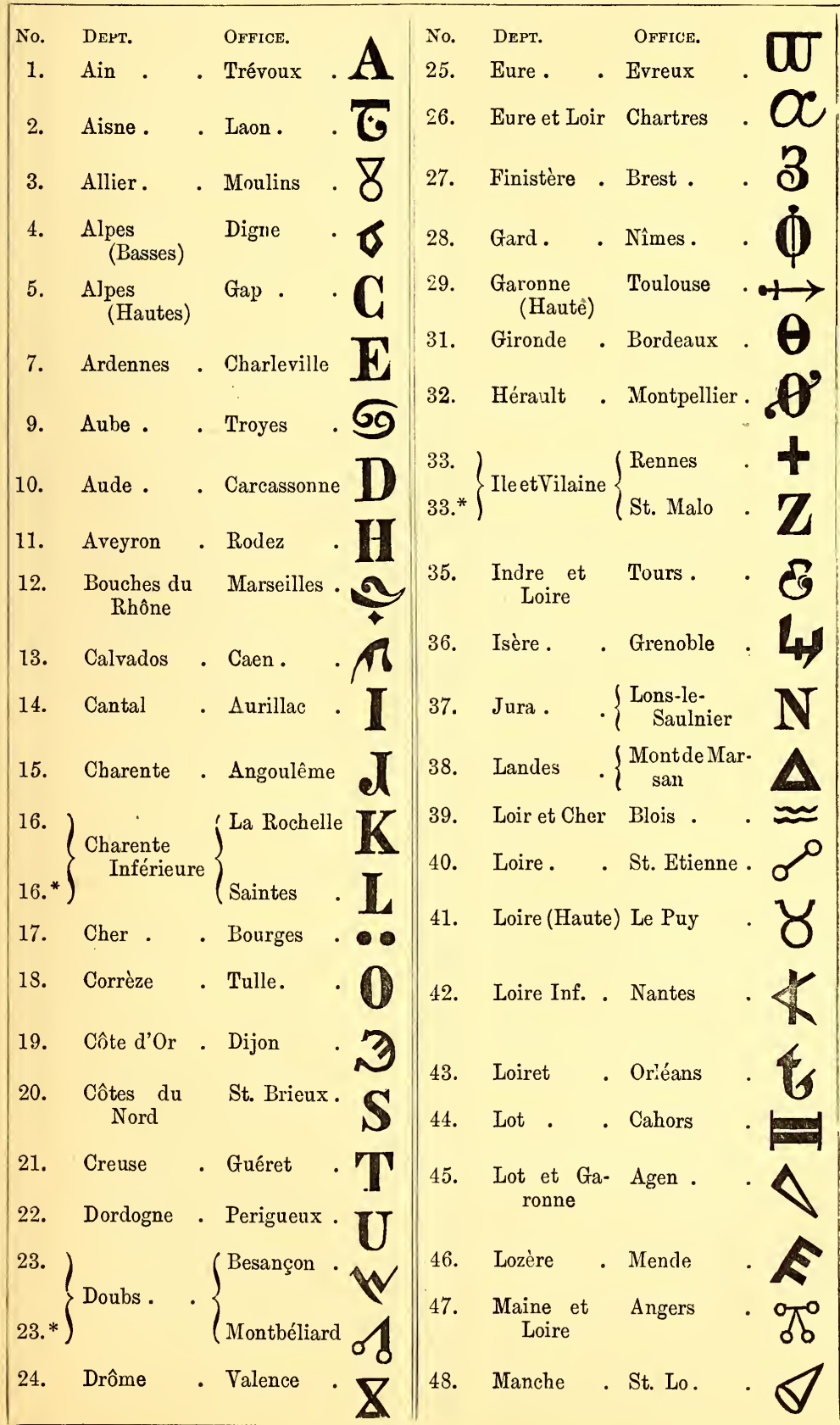


Alphabetical List of Departments, ETc.-continued.

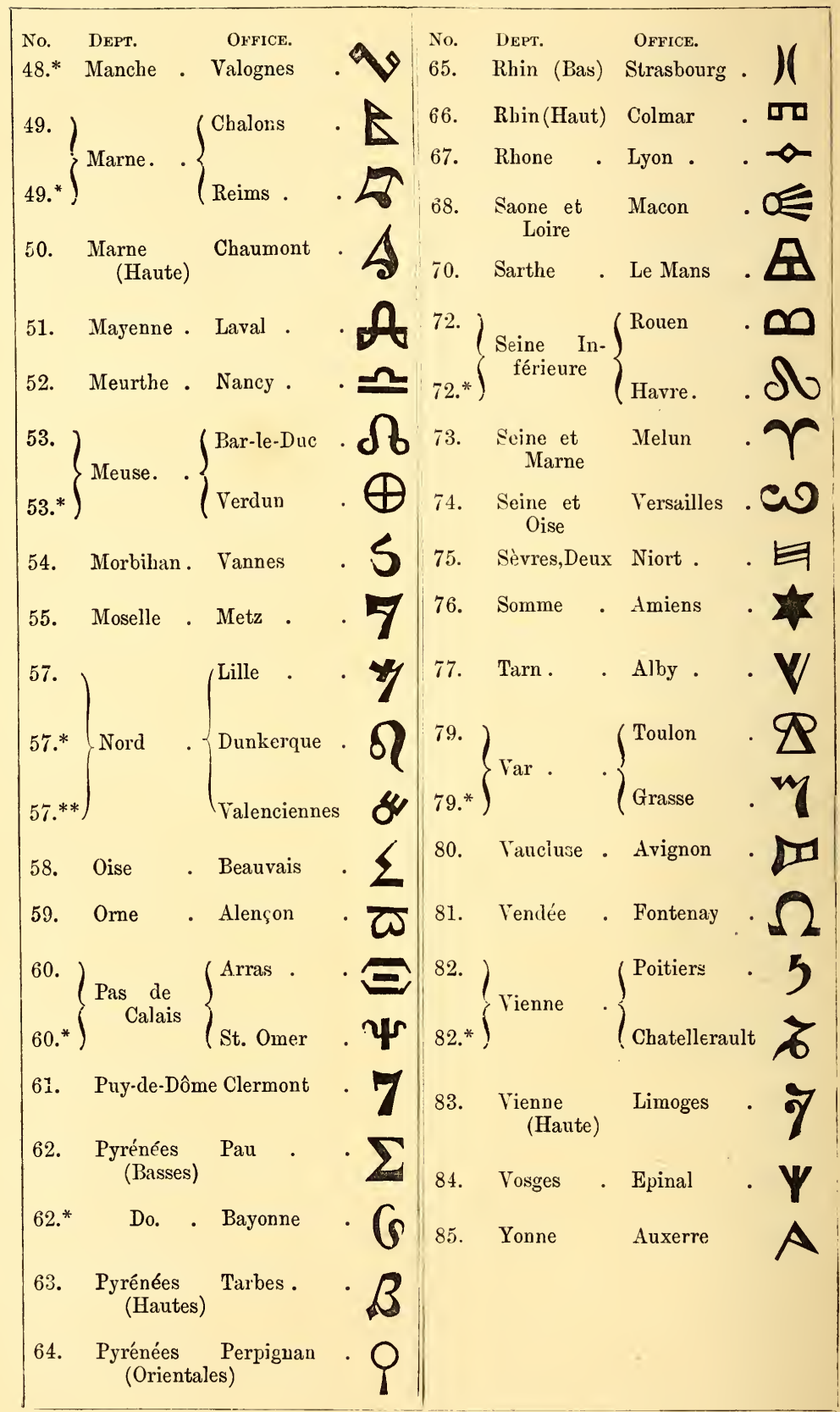




\section{APPENDIX.}

\section{CHRONOLOGICAL LIST}

OF

\section{SPECIMENS OF OLD FRENCH PLATE, WITH \\ THE MARKS OF THE MAKERS.}

PART I.-Period anterior to 1672.

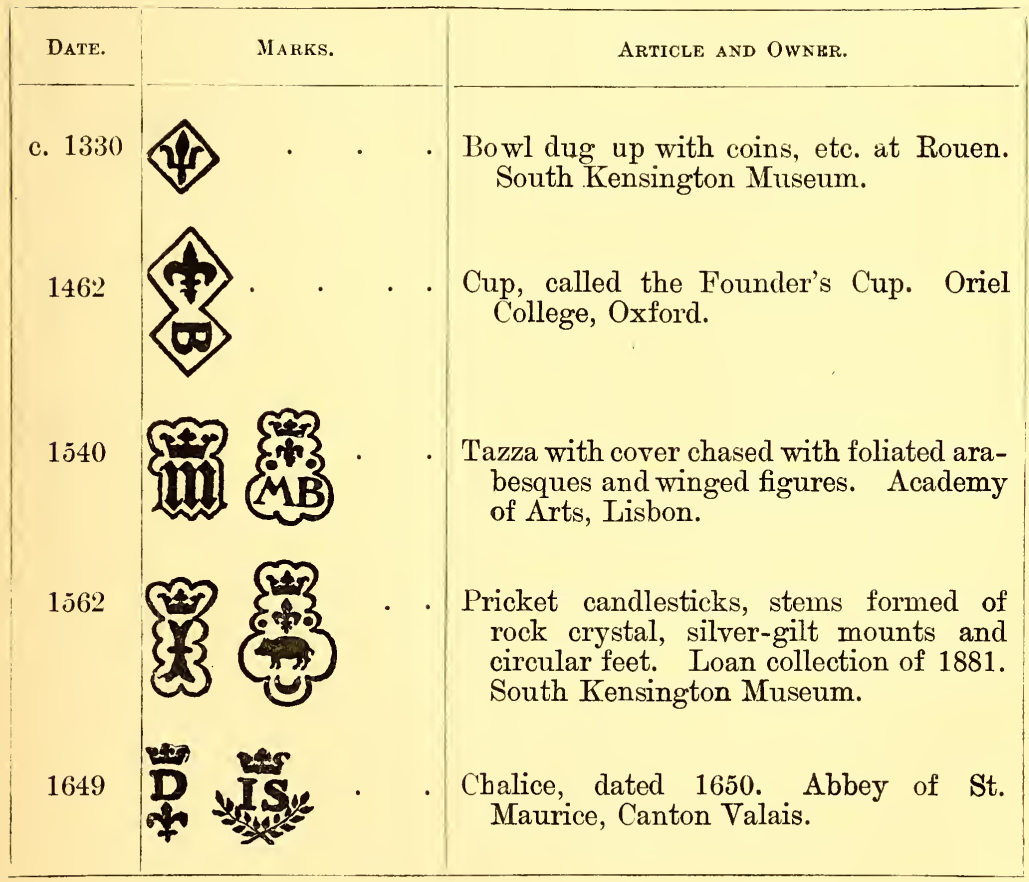




\section{Part I.-continued.}

The four following have the maker's mark only :-

\begin{tabular}{|l|l|l|}
\hline c. 1675 \\
c. 1680 \\
Do. 1690
\end{tabular}




\section{PaRT II.-Period from 1672.}

\begin{tabular}{|c|c|c|c|}
\hline Date. & $\begin{array}{l}\text { MAKER'S MARK } \\
\text { AND DIFFÉRENT. }\end{array}$ & NAME. & ARTICLE AND OWNER. \\
\hline $167 j$ & LP anchor & $\begin{array}{l}\text { Qy. Louis } \mathrm{Plu}- \\
\text { viers. }\end{array}$ & $\begin{array}{l}\text { Small bowl, part of toilet service. } \\
\text { Rosenborg Collection, Copen- } \\
\text { hagen. }\end{array}$ \\
\hline Do. & $\begin{array}{l}\text { CB flower } \\
\text { spray. }\end{array}$ & $\begin{array}{l}\text { Qy. Claude Bal- } \\
\text { lin. }\end{array}$ & Small toy pilgrim-bottle. Do. \\
\hline Do. & GL éto & $\begin{array}{l}\text { Qy. Guillaume } \\
\text { Lucas. }\end{array}$ & $\begin{array}{l}\text { Crucifix. Messrs. Lamberts, } \\
\text { London. }\end{array}$ \\
\hline 1701 & $\begin{array}{c}\text { IB } \\
\text { L }\end{array}$ & J. Baptiste Loir & $\begin{array}{l}\text { Two vases with handles. Pichon } \\
\text { Collection. }\end{array}$ \\
\hline 1708 & GMI étoile & Grégoire Masse & Huilier. Pichon and Eudel C \\
\hline 1710 & LL Ste. Esprit & Louis Loir & $\begin{array}{l}\text { Flambeaux. Pichon and Eudel } \\
\text { Collections. }\end{array}$ \\
\hline 1714 & AJ vase . & Antoine Jossey . & Bougeoir. Eudel Collection. \\
\hline 1716 & JQ & Jean Quin & $\begin{array}{l}\text { Boite à éponges. Pichon and } \\
\text { Eudel Collections. }\end{array}$ \\
\hline Do. & PP casque & . . & $\begin{array}{l}\text { Tumbler cup. Wilfred Cripps, } \\
\text { Esq., C.B. }\end{array}$ \\
\hline 1720 & NL . & Noel Léonard . & $\begin{array}{l}\text { Salt cellars. Noted by late Oct. } \\
\text { Morgan, Esq. }\end{array}$ \\
\hline 1722 & MB raisin & Martin Berthe . & Flambeaux. Eudel Collection. \\
\hline Do. & $\begin{array}{c}\text { JM lance with } \\
\text { pennon } \\
\text { upright }\end{array}$ & 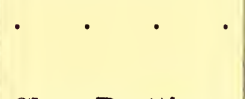 & $\begin{array}{l}\text { ndlesticks, Regency style. } \\
\text { by the author in Russia. }\end{array}$ \\
\hline 1723 & CR ring . . & Chas. Roettiers. & $\begin{array}{l}\text { Centrepiece or surtout de table. } \\
\text { Imperial Collections, Russia. }\end{array}$ \\
\hline Do. & . & . & $\begin{array}{l}\text { Pair of octagonal boxes. Lord } \\
\text { Bateman. }\end{array}$ \\
\hline 1724 & NN étoile & & $\begin{array}{l}\text { Candlesticks, Regency style. } \\
\text { Earl of Ilchester. }\end{array}$ \\
\hline 1725 & RMI étoile & Robt. Mognart . & Aiguière. Eudel Collection. \\
\hline Do. & $\stackrel{\text { CF }}{\mathbf{C}}$ & $\begin{array}{l}\text { Chas. } \\
\text { Croze. }\end{array}$ & $\begin{array}{l}\text { Flambeau à deux umières. } \\
\text { Pichon Collection. }\end{array}$ \\
\hline Do. & $\underset{\text { S.N }}{\text { A }}$ rose & $\begin{array}{l}\text { Antoine de St. } \\
\text { Nicholas. }\end{array}$ & $\begin{array}{l}\text { Ecuelle. Noted by the author in } \\
\text { Russia. }\end{array}$ \\
\hline 1726 & Do. & Do. & $\begin{array}{l}\text { veau à huit pans. Eudel } \\
\text { ection. }\end{array}$ \\
\hline Do. & PS & Paul Soulaine & $\begin{array}{l}\text { Flambeaux triangulaires. Pichon } \\
\text { Collection. }\end{array}$ \\
\hline 1727 & I工 Ste. Esprit & Probably Loir & $\begin{array}{l}\text { re, motives maritimes. Eu- } \\
\text { ollection. }\end{array}$ \\
\hline
\end{tabular}




\begin{tabular}{|c|c|c|c|}
\hline DAte. & $\begin{array}{l}\text { MAKER'S MARK } \\
\text { AND DIFFÉRENT. }\end{array}$ & NAME. & ARTICLE AND OWNER. \\
\hline 1728 & RC . & Remy Chatria . & Salières. Pichon Collection, \\
\hline Do. & NB & Nicholas Besnier & Sucrier. Do. \\
\hline 1729 & IF marteau & . & $\begin{array}{l}\text { Tall sugar-castor, Regency style. } \\
\text { Late Sir R. Wallace, Bart. }\end{array}$ \\
\hline 1732 & II acorn & . . & $\begin{array}{l}\text { Théière. South Kensington } \\
\text { Museum. }\end{array}$ \\
\hline 1733 & T G toison & Thos. Germain . & $\begin{array}{l}\text { Ecuelle en vermeil. Demidofi, } \\
\text { Double, and Eudel Collections. }\end{array}$ \\
\hline Do. & NO & Nic. Outrebon & $\begin{array}{l}\text { Jattes ou compotiers. Pichon } \\
\text { Collection. }\end{array}$ \\
\hline Do. & AP. & Antoine Plot & Deux plateaux à contours. Do. \\
\hline Do. & $\begin{array}{c}\text { CI } \\
\mathbf{C}\end{array}$ & . & $\begin{array}{l}\text { Snuff-box of jewelled St. Cloud } \\
\text { ware. Late Octavius Morgan, } \\
\text { Esq. }\end{array}$ \\
\hline 1734 & $\stackrel{\mathbf{P}}{\text { FB }}$ fleur & $\begin{array}{l}\text { Probably Pierre } \\
\text { Fras. Bonne- } \\
\text { straine. }\end{array}$ & $\begin{array}{l}\text { Soupière, shell-fish on the cover. } \\
\text { Noted by the author in Russia. } \\
\text { Signed " Fait par J. A. Meis- } \\
\text { sonnier, architecte." }\end{array}$ \\
\hline Do. & $\begin{array}{l}\text { IR pot-aux - } \\
\text { fleurs }\end{array}$ & Jacques Roettiers & $\begin{array}{l}\text { Centre-piece, with stag and } \\
\text { hounds and a wolf in a trap. } \\
\text { Noted by the author in Russia. }\end{array}$ \\
\hline Do. & TG toison & Thos. Germain & $\begin{array}{l}\text { Flambeaux. Lord Amherst of } \\
\text { Hackney. }\end{array}$ \\
\hline 1736 & IR & . & Salts. Lord Fitzhardinge. \\
\hline Do. & IB cinquefoil & • & $\begin{array}{l}\text { Ecuelle. Late Sir Rich. Wallace, } \\
\text { Bart. }\end{array}$ \\
\hline 1737 & CP étoile & . & $\begin{array}{l}\text { Table spoon. Noted by author } \\
\text { in Edinburgh. }\end{array}$ \\
\hline Do. & TG toison & See 1734 & Flambeau. Pichon Collection. \\
\hline 1738 & $\begin{array}{l}\text { JR pot-aux- } \\
\text { fleurs }\end{array}$ & Jacques Roettiers & $\begin{array}{l}\text { Soupière. Late Duke of Somer- } \\
\text { set. Signed "J. RoETIERS INET } \\
\text { FECIT A PARIS 1739." }\end{array}$ \\
\hline 1739 & AH couronne & $\begin{array}{l}\text { Qy. Antoine Her- } \\
\text { bault. }\end{array}$ & $\begin{array}{l}\text { Tall chalice on baluster-stem. } \\
\text { Noted by author in Paris. }\end{array}$ \\
\hline 1743 & CR bague & See 1723 . . & $\begin{array}{l}\text { Candlesticks with two branches. } \\
\text { Noted by author in Russia. }\end{array}$ \\
\hline Do. & LR rénard & Louis Regnard & $\begin{array}{l}\text { Paire de candélabres. Eudel } \\
\text { Collection. }\end{array}$ \\
\hline Do. & & P. J. Antoine & $\begin{array}{l}\text { Tabatière. Lenoir Don, Musée } \\
\text { du Louvre. }\end{array}$ \\
\hline 1744 & TG toison & See 1734 & $\begin{array}{l}\text { Salt-cellars. The Royal Collec- } \\
\text { tion, Copenhagen. }\end{array}$ \\
\hline $\begin{array}{r}1744 \\
-50\end{array}$ & $\underset{\mathbf{B}}{\mathbf{E P}}$ cinquefoil & $\begin{array}{l}\text { Edmé } \text { Pierre } \\
\text { Balsac. }\end{array}$ & $\begin{array}{l}\text { Dish. Late Sir Rich. Wallace, } \\
\text { Bart. }\end{array}$ \\
\hline
\end{tabular}




\begin{tabular}{|c|c|c|c|}
\hline DATE. & $\begin{array}{l}\text { MAKER's MARK } \\
\text { AND DIFFÉRENT. }\end{array}$ & NAME. & ARTICLE AND OWNER. \\
\hline 1745 & $\begin{array}{l}\text { CC } \\
\text { H }\end{array}$ & $\begin{array}{l}\text { Chas. César } \\
\text { Haudry. }\end{array}$ & $\begin{array}{l}\text { Deux saucières. Eudel Collec- } \\
\text { tion. }\end{array}$ \\
\hline Do. & PE étoile. & $\begin{array}{l}\text { Pierre Etienne } \\
\text { Buron. }\end{array}$ & $\begin{array}{l}\text { Plateau aux armes de Bragance. } \\
\text { Foz Collection. }\end{array}$ \\
\hline 1746 & AL lampe & Alexis Loir & $\begin{array}{l}\text { Ecuelle with cover and stand. } \\
\text { Late Sir Rich. Wallace Bart. }\end{array}$ \\
\hline $17+7$ & TG toison & See 1734 & Flambeau. Pichon Collection. \\
\hline 1748 & $\underset{\mathbf{B}}{\mathbf{J F}}$ rosace & $\begin{array}{l}\text { Jean Fras. Bal- } \\
\text { sac. }\end{array}$ & Huilier. Eudel Collection. \\
\hline Do. & SB & Simon Bourguet & Ecuelle. Pichon Collection. \\
\hline 1750 & $\begin{array}{l}\text { LG coquille } \\
\text { T (escallop) }\end{array}$ & - & $\begin{array}{l}\text { Cup with two handles and cover. } \\
\text { South Kensington Museum. }\end{array}$ \\
\hline 1753 & MIM tulipe & Mathieu, de & Gobelet. Eudel Collection. \\
\hline Do. & CI fleur & & $\begin{array}{l}\text { Snuff-box. Mitchell Collection, } \\
\text { South Kensington Museum. }\end{array}$ \\
\hline $17 \check{17}$ & JD . & Jean Ducrollay . & $\begin{array}{l}\text { Snuff-box. Lenoir Don, Musée } \\
\text { du Louvre. }\end{array}$ \\
\hline Do. & JM & Jean Moynat & Do. \\
\hline 1755 & $\begin{array}{l}\text { JP } \\
\text { MI marteau . }\end{array}$ & $\begin{array}{l}\text { Jean Pierre } \\
\text { Marteau. }\end{array}$ & Plat à poulet. Eudel Collection. \\
\hline Do. & $\underset{\mathbf{G}}{\mathbf{J F}}$ oiseau & $\begin{array}{l}\text { Jean Fras. Go- } \\
\text { get. }\end{array}$ & Plat d'entrée. Do. \\
\hline Do. & $\begin{array}{l}\text { JC } \\
\text { D }\end{array}$ & $\begin{array}{l}\text { Jean Chas. Du- } \\
\text { crollay. }\end{array}$ & $\begin{array}{l}\text { Snuff-box. Lenoir Don, Musée } \\
\text { du I Louvre. }\end{array}$ \\
\hline Do. & $\mathbf{A D}$ arbre & . & $\begin{array}{l}\text { Snuff-box, Louis XV. style. Late } \\
\text { Octavius Morgan, Esq. }\end{array}$ \\
\hline 1757 & $\underset{\mathbf{A}}{\mathbf{R J}}$ cornucopi & $\begin{array}{l}\text { Robt. Jacques } \\
\text { Auguste. }\end{array}$ & $\begin{array}{l}\text { Soupières, Louis XV. style. The } \\
\text { Royal Collection, Copenhagen. } \\
\text { Signed "Auguste fecit." }\end{array}$ \\
\hline 1758 & 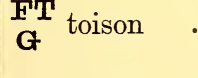 & $\begin{array}{l}\text { Fras. Thos. Ger- } \\
\text { main. }\end{array}$ & $\begin{array}{l}\text { Très beaux flambeaux. Eudel } \\
\text { Collection. }\end{array}$ \\
\hline Do. & HA globe & Henri Alain & Bougeoir. Do. \\
\hline 1761 & JF étoile & $\begin{array}{c}\text { Jacques } \\
\text { Varin. }\end{array}$ & Cafetière. Do. \\
\hline Do. & • & A. M. Dumel . & Gobelet. Do. \\
\hline Do. & JY colonne & - & $\begin{array}{l}\text { Snuff-box. Mitchell Collection, } \\
\text { South Kensington Museum. }\end{array}$ \\
\hline
\end{tabular}




\begin{tabular}{|c|c|c|c|}
\hline Date. & $\begin{array}{l}\text { MAKER's MARK } \\
\text { AND DIFFÉREN'T. }\end{array}$ & NAME. & ARTICLE AND OWNER. \\
\hline 1762 & F'J cœur . . & Fras. Joubert & Boîte à brosses. Eudel Collec- \\
\hline Do. & $\cdot$ & P. J. Bellangé & $\begin{array}{l}\text { Tabatière. Lenoir Don, Musée } \\
\text { du Louvre. }\end{array}$ \\
\hline Do. & $\mathbf{A J}$ étoile . & $\begin{array}{l}\text { Antoine Jean de } \\
\text { Villeclair. }\end{array}$ & $\begin{array}{l}\text { Soupière. San Donato, Pichon } \\
\text { and Eudel Collections. }\end{array}$ \\
\hline Do. & JG & Jean George & $\begin{array}{l}\text { Snuff-box. Lenoir Don, Musée } \\
\text { du Louvre. }\end{array}$ \\
\hline Do. & $\mathbf{F C}$ point & & $\begin{array}{l}\text { Snuff-box. Mitchell Collection, } \\
\text { South Kensington Museum. }\end{array}$ \\
\hline 1763 & TR & Mathieu Coiny . & $\begin{array}{l}\text { Snuff-box. Lenoir Don, Musée } \\
\text { du Louvre. }\end{array}$ \\
\hline Do. & JB clef . & $\begin{array}{l}\text { Jean Baptiste } \\
\text { Cheret. }\end{array}$ & Huilier. Chas. A. North, Esq. \\
\hline Do. & $\underset{\mathbf{B}}{\mathbf{N C}}$ cinquefoil & . & $\begin{array}{l}\text { Silver boxes fitting together. M. } \\
\text { de Falbe. }\end{array}$ \\
\hline 1764 & LL colonne . & $\begin{array}{l}\text { Louis Thos. Len- } \\
\text { hendrick. }\end{array}$ & Flambeaux. Eudel Collection. \\
\hline Do. & $\cdot \cdot$ & C. B. Sageret . & $\begin{array}{l}\text { Tabatière. Lenoir Don, Musée } \\
\text { du Louvre. }\end{array}$ \\
\hline Do. & $\underset{\mathbf{G}}{\mathbf{F T}}$ toison & See $175 \mathrm{~s}$ & Chocolatière. Pichon Collection. \\
\hline 1765 & $\begin{array}{l}\text { JT triangle or } \\
\text { plomb. }\end{array}$ & $\cdot$ & $\begin{array}{l}\text { Snuff-box. Mitchell Collection, } \\
\text { South Kensington Museum. }\end{array}$ \\
\hline Do. & $\underset{\mathbf{R}}{\mathrm{AD}}$ two palms & $\begin{array}{l}\text { Alexandre de } \\
\text { Roussy. }\end{array}$ & $\begin{array}{l}\text { Ecuelle with cover. Noted by } \\
\text { author in Russia. }\end{array}$ \\
\hline Do. & JD . & Qj. Jean Duché & $\begin{array}{l}\text { Aiguière avec cuvette. Late Sir } \\
\text { Rich. Wallace, Bart. }\end{array}$ \\
\hline 1766 & $\underset{\mathbf{C}}{\mathrm{JB}}$ clef & See 1763 & $\begin{array}{l}\text { Petite cafetière. Pichon Collec- } \\
\text { tion. }\end{array}$ \\
\hline Do. & FJ cœur & See 1762 & Sucrier. Do. \\
\hline Do. & - mitre . . & H. N. de Brie & Cafetière. Eudel Collection. \\
\hline 1767 & AJ cornucopia & See $17 \overline{7} 7$ & $\begin{array}{l}\text { Salts with shells and amorini. } \\
\text { Count Bobrinsky, Moscow. }\end{array}$ \\
\hline 1768 & $\begin{array}{l}\text { PF crois de } \\
\text { M Malte. }\end{array}$ & P. F. Marchand & Gobelet. Eudel Collection. \\
\hline Do. & JB étoile & Julien B. Petit . & Huilier. Do. \\
\hline Do. & $\begin{array}{l}\text { PS } \\
\mathbf{M}\end{array}$ & $\cdot$ & $\begin{array}{l}\text { Snuff-box, gold and green, with } \\
\text { miniatures. Earl of Ilchester. }\end{array}$ \\
\hline
\end{tabular}




\begin{tabular}{|c|c|c|c|}
\hline DAte. & $\begin{array}{l}\text { MAKER's MaRk } \\
\text { AND DIFFÉRENT. }\end{array}$ & NAME. & ARTICLE AND OWNER. \\
\hline 1769 & CI étoile & . . & $\begin{array}{l}\text { Snuff-box. Mitchell Collection, } \\
\text { South Kensington Museum. }\end{array}$ \\
\hline Do. & II colonne . & See 1764 . & $\begin{array}{l}\text { Soupières on lion feet, military } \\
\text { motives. The Imperial Collec- } \\
\text { tions, St. Petersburg. }\end{array}$ \\
\hline 1770 & DF triangle . & Denis Franckson & Moutardier. Pichon Collection. \\
\hline 1772 & $\mathbf{P A} \cdot \cdot \cdot \cdot$ & & $\begin{array}{l}\text { Snuff-box. Mitchell Collection, } \\
\text { South Kensington Museum. }\end{array}$ \\
\hline 1773 & $\begin{array}{l}\mathbf{L} \mathbf{H}^{\prime} \\
\mathrm{T}\end{array}$ & $\begin{array}{l}\text { Qy. Louis Fras. } \\
\text { Auguste Tau- } \\
\text { nay. }\end{array}$ & Do. \\
\hline Do. & $\stackrel{\text { CA }}{\mathbf{B}}$ & $\begin{array}{l}\text { Chas. Alex. } \\
\text { Bouillerot. }\end{array}$ & $\begin{array}{l}\text { Snuff-box. Mitchell Collection, } \\
\text { South Kensington Museum. }\end{array}$ \\
\hline Do. & FJ cœur & See 1762 & $\begin{array}{l}\text { Aiguière with swan on lid. Late } \\
\text { Sir Rich. Wallace, Bart. }\end{array}$ \\
\hline Do. & GP canard . & $\cdot \quad \cdot \quad \cdot \cdot$ & Noted by author in London. \\
\hline 1774 & $\underset{\mathbf{B}}{\mathrm{JE}}$ & $\begin{array}{l}\text { Joseph Etienne } \\
\text { Blerzy. }\end{array}$ & $\begin{array}{l}\text { Snuff-box. Lenoir Don, Musée } \\
\text { du Louvre. }\end{array}$ \\
\hline Do. & $\overline{\mathbf{B}}^{\mathbf{R}}$ lapin & $\begin{array}{l}\text { Qy. Michel Réné } \\
\text { Bocher. }\end{array}$ & $\begin{array}{l}\text { Snuff-box. Mitchell Collection, } \\
\text { South Kensington Museum. }\end{array}$ \\
\hline 1775 & $\underset{\mathrm{D}}{\mathrm{CH}}$ soleil & C. H. Delanoy & $\begin{array}{l}\text { Saucière (avec plateau de 1776). } \\
\text { Pichon and Eudel Collections. }\end{array}$ \\
\hline Do. & JT lis & $\begin{array}{l}\text { J.T. Vanconver- } \\
\text { berghen. }\end{array}$ & Chocolatière. Do. \\
\hline Do. & $\mathbf{A B} \cdot \cdot \cdot \cdot$ & Antoine Boullier & $\begin{array}{l}\text { Cafetière à trois pieds. Pichon } \\
\text { Collection. }\end{array}$ \\
\hline Do. & $\begin{array}{l}\text { RJ } \\
\text { A }\end{array}$ & See $17 j 7$ & $\begin{array}{l}\text { Table candlesticks, Louis XVI. } \\
\text { style. The Royal Collections, } \\
\text { Stockholm. }\end{array}$ \\
\hline 1776 & CS Ste. Esprit & Chas. Spriman . & $\begin{array}{l}\text { Plateau pour saucière de } 1775 . \\
\text { Pichon and Eudel Collections. }\end{array}$ \\
\hline Do. & — coquille & Jacques de Boy. & Ecuelle avec plateau. Do. \\
\hline Do. & $\begin{array}{l}\text { JL aigle . } \\
\text { M }\end{array}$ & Louis Mermant. & Gobelet. Do. \\
\hline Do. & $\underset{\mathbf{A}}{\mathbf{R J}}$ cornucopia & See 1757 & $\begin{array}{l}\text { Soupière. The Imperial Collec- } \\
\text { tions, St. Petersburg. }\end{array}$ \\
\hline Do. & $\mathbf{N C} \operatorname{coq}$ & - & Wilfred Cripps, Esq., C.B. \\
\hline 1777 & AS . & Alex. Savart & $\begin{array}{l}\text { Petite cafetière. Pichon and Eudel } \\
\text { Collections. }\end{array}$ \\
\hline
\end{tabular}




\begin{tabular}{|c|c|c|c|}
\hline Date. & $\begin{array}{l}\text { MAKER'S MARK } \\
\text { AND DIFFÉRENT. }\end{array}$ & NAME. & ARticle aNd OWNer. \\
\hline 1777 & $\underset{\mathbf{R}}{\mathbf{A D}}$ two palms & See $176 j$ & $\begin{array}{l}\text { Saucière. Pichon and Eudel } \\
\text { Collections. }\end{array}$ \\
\hline Do. & $\underset{\mathbf{R}}{\mathbf{G F}}$ boule & $\begin{array}{l}\text { Guillaume Fras. } \\
\text { Rolland. }\end{array}$ & Moutardier. Do. \\
\hline Do. & $\begin{array}{l}\text { JJ coquille } \\
\text { D (escallop) }\end{array}$ & $\begin{array}{l}\text { Jacques Joseph } \\
\text { Demay. }\end{array}$ & Truelle à poisson. Do. \\
\hline Do. & $\underset{\mathbf{J}}{\mathrm{ME}}$ marc & $\begin{array}{l}\text { Marc Etienne } \\
\text { Janety. }\end{array}$ & $\begin{array}{l}\text { Paire de salières. Pichon and } \\
\text { Eudel Collections. }\end{array}$ \\
\hline Do. & ${ }_{\mathbf{B}}^{\mathbf{J A}}$ point & $\begin{array}{l}\text { Jacques Antoine } \\
\text { Bonhomme. }\end{array}$ & Deux plats. Eudel Collection. \\
\hline 1778 & PD étoile & $\begin{array}{l}\text { Pierre Désiré } \\
\text { Bullot. }\end{array}$ & Gobelet. Do. \\
\hline Do. & CS Ste. Esprit & See 1776 . & Ecuelle avec anses. Pichon Col- \\
\hline 79 & BP . & $\begin{array}{l}\text { Barthélemy Pil- } \\
\text { lieu. }\end{array}$ & $\begin{array}{l}\text { Snuff-box. Lenoir Don, Musée } \\
\text { du Louvre. }\end{array}$ \\
\hline 1780 & JR hermine & Jean Roger & Plat. Eudel Collection. \\
\hline Do. & AB pied . . & Antoine Brigal . & Rechaud à esprit de vin. Do. \\
\hline Do. & JF pistolet & . & $\begin{array}{l}\text { Chocolate pot, style de Louis XVI. } \\
\text { M. de Falbe. }\end{array}$ \\
\hline Do. & $\underset{\mathbf{B}}{\mathbf{C L}}$ cinquefo l & See 1769 & $\begin{array}{l}\text { Snuff-box. Late Octavius Morgan, } \\
\text { Esq. }\end{array}$ \\
\hline 1781 & $\begin{array}{l}\text { NG crosse } \\
\text { d'évêque }\end{array}$ & $\cdot \quad \cdot \quad \cdot$ & Cup. Wilfred Cripps, Esq., C.B. \\
\hline Do. & $\underset{\mathrm{B}}{\mathrm{JA}}$ & See 1777 & $\begin{array}{l}\text { Vegetable dish with pom egranate } \\
\text { on the cover. Noted by author } \\
\text { in Russia. }\end{array}$ \\
\hline Do. & $\begin{array}{l}\text { JL } \\
\text { AG }\end{array}$ & $\begin{array}{l}\text { Qy. L. A. Grou- } \\
\text { velle. See } 1785 \\
\text {-7. }\end{array}$ & Cup. Noted by author in Kent. \\
\hline Do. & JLO • & $\begin{array}{l}\text { J. L. D. Outre- } \\
\text { bon. }\end{array}$ & $\begin{array}{l}\text { Cuillers. Pichon and Eudel Col- } \\
\text { lections. }\end{array}$ \\
\hline Do. & $\mathrm{JE}$ & See 1774 & $\begin{array}{l}\text { Snuff-box. Lenoir Don, Musée } \\
\text { du Louvre. }\end{array}$ \\
\hline 1782 & $\underset{\mathbf{F}}{\mathbf{R P}} \operatorname{coq}$ & $\begin{array}{l}\text { Réné Pierre } \\
\text { Ferrier. }\end{array}$ & Huilier. Eudel Collection. \\
\hline Do. & $\underset{\mathbf{B}}{\mathbf{F C}}$ baton. & $\begin{array}{l}\text { Fred. Chas. } \\
\text { Bachman. }\end{array}$ & Bain-marie. Eudel Collection. \\
\hline
\end{tabular}




\begin{tabular}{|c|c|c|c|c|}
\hline DATE. & $\begin{array}{l}\text { MAKER'S MARK } \\
\text { AND DIFFÉRENT. }\end{array}$ & & NAME. & ARTiCle AND OWNER. \\
\hline 1782 & $\mathbf{D F}$ & . & See 1770 . & $\begin{array}{l}\text { Huilier sur terrasse. Pichon } \\
\text { Collection. }\end{array}$ \\
\hline 1783 & B grenade & & $\begin{array}{l}\text { Claude Isaac } \\
\text { Bourgoin. }\end{array}$ & $\begin{array}{l}\text { Bassin. Pichon and Eudel Col- } \\
\text { lections. }\end{array}$ \\
\hline Do. & ${ }_{\mathbf{B}}^{\mathbf{C F}}$ cœur & & $\begin{array}{l}\text { Chas. Etienne } \\
\text { Berrubé. }\end{array}$ & Flambeaux. Do. \\
\hline Do. & $\mathrm{AB}$. & . & See 1775 & $\begin{array}{l}\text { Aiguière avec cuvette. Late Sir } \\
\text { Rich. Wallace, Bart. }\end{array}$ \\
\hline 1784 & Do. & . & Do. . & $\begin{array}{l}\text { Soup tureens. Princess Souwa- } \\
\text { roff. Signed "A. BOULLIER. } \\
\text { F. A. PARIS." }\end{array}$ \\
\hline Do. & $\begin{array}{c}\text { RJ } \\
\mathbf{A}\end{array}$ & & See 1757 & $\begin{array}{l}\text { Set of gilt salvers. The Royal } \\
\text { Collections, Stockholm. }\end{array}$ \\
\hline Do. & $\underset{\mathbf{J}}{\mathrm{ME}}$ & - & See 1777 & $\begin{array}{l}\text { Vase with cover (oval), Louis } \\
\text { XVI. style. Noted by author } \\
\text { at Messrs. Christie, Manson \& } \\
\text { Woods. }\end{array}$ \\
\hline Do. & C & - & See 1763 & $\begin{array}{l}\text { Toilet-boxes, with arms of De } \\
\text { Rohan. A. W. Franks, Esq., } \\
\text { C.B. }\end{array}$ \\
\hline 1785 & $\underset{\mathbf{S}}{\mathbf{N}} \operatorname{cup}$ & - & J. N. Sacher & Cafetière. Eudel Collection. \\
\hline$\frac{178 j}{-7}$ & - croissant & • & $\begin{array}{l}\text { Louis Antoine } \\
\text { Grouvelle. }\end{array}$ & Gobelets. Do. \\
\hline 1788 & $\underset{\mathbf{B}}{\mathbf{J}} \operatorname{coq}$ & & . & $\begin{array}{l}\text { Vegetable dish with cover. Noted } \\
\text { by author in Russia. }\end{array}$ \\
\hline 1789 & $\underset{\mathbf{M}}{\mathbf{M F}}$ lambel & & $\begin{array}{l}\text { Michel Fras. } \\
\text { Montaigne. }\end{array}$ & Grand gobelet. Eudel Collection. \\
\hline $\begin{array}{c}c . \\
1788\end{array}$ & JE equerre & & See 1774 & $\begin{array}{l}\text { Snuff-box. Mitchell Collection, } \\
\text { South Kensington Museum. }\end{array}$ \\
\hline Do. & $\begin{array}{l}\mathbf{P C} \text { crois de } \\
\mathbf{P} \text { Malte. }\end{array}$ & & $\cdot$ & Do. \\
\hline $\begin{array}{c}\text { c. } \\
1780 \\
-9\end{array}$ & $\begin{array}{c}\mathbf{F M} \\
\mathbf{M}\end{array}$ étoile & & $\begin{array}{l}\text { Fras. Michel } \\
\text { Montaigne. }\end{array}$ & Bougeoir. Eudel Collection. \\
\hline
\end{tabular}





\section{INDEX.}

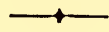

A.

A, Paris mint letter

A A, Metz mint letter . . . . . . . . . . 65

Alphabetical date-letters, introduction of : . . . . . . 19

letters, as Mint marks _ . . . . . . 27,64

\&, Aix mint mark . . . . . . . . . . 57,65

Apprentices, regulations as to . . . . . . . . . 10

Argent le roy . . . . . . . . . . . . . . 6, 13,14

Arms of towns, anciently used as marks _ . . . . . 20,51

$, \quad, \quad$ table of . . . . . . . . . . 58

B.

$\mathrm{B}$, Rouen mint letter . $\quad . \quad$. $\quad . \quad$. $\quad . \quad$. $\quad 64,66$

B B, Strasbourg mint letter . . . . . . . . . 54

Ballin, Claude . . . . . . . . . . . . 25,48

, Jacques . . . . . . . . . . . . 48

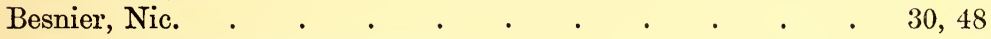

Bigorne countermarks, how used . . . . . . . . $\quad$. 87

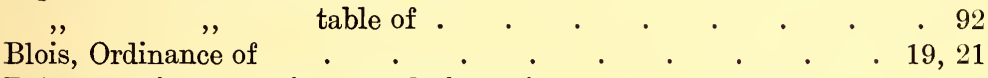

Boileau, Etienne, ancient regulations of $\quad$. $\quad$. $\quad$. $\quad$. $\quad$. 9

Bordeaux, goldsmiths of, and their marks . . . . . 15, 64, 66

Borihls, what . . . . . . . . . . . 16

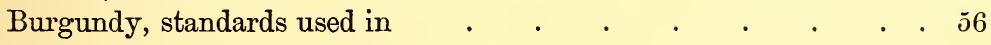

C.

C, Caen mint letter . $\quad . \quad$. $\quad . \quad$. $\quad . \quad$. $\quad . \quad$. 64

Carat measure, when abolished . . . . . . . . 5

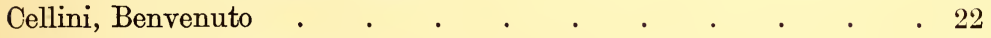

Chains, remarque for gold . . . . . . . . . . 87

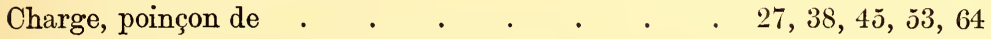

Cock, a standard mark under the Republic . . . . . 83, 86, 88 
Coin, standards of French gold and silver .

D.

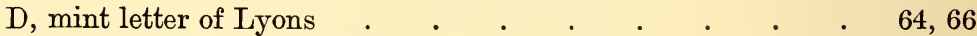

Date-letters, tables of Parisian . . . . . . . . 40

Décharge, poinçon de . . . . . . . . . $27,38,45,64$

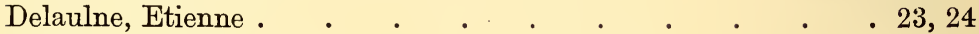

Deniers, a weight $\quad . \quad$. $\quad . \quad$. $\quad . \quad$. $\quad . \quad$. $\quad .2$

Departments, marks used for the different . . . . . . 93, 97

Destruction of plate at various epochs _ . . . . . . 26, 33

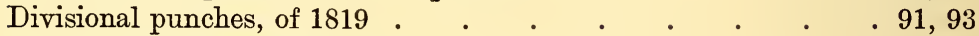

Droit de marque, imposition of . . . . . . . . . 27

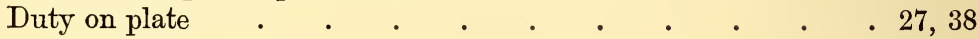

E.

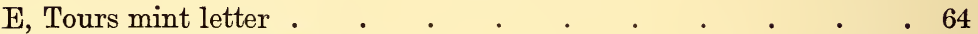

Esterlins, an ancient weight . . . . . . . . . 2

$\mathrm{E} \mathrm{T}$, a mark for foreign wares $\quad . \quad$. $\quad . \quad$. $\quad .35,83,88,89$

F.

F, Angers mint letter . $\quad . \quad$. $\quad . \quad$. $\quad . \quad$. 54

Fermier-général, marks used by the . . . . 27, 38, 45, 53, 64

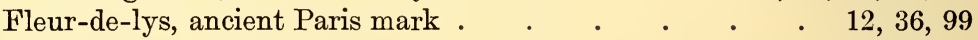

Fontainebleau, edict of . . . . . . . . . $\quad$. 23

Foreign wares, marks used to distinguish ․ . $35,83,88,89,90,95$

G.

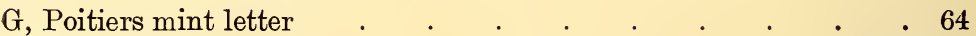

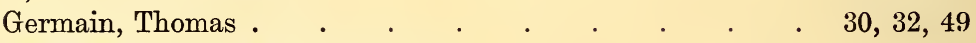

Gobelins, school of goldsmiths' art . . . . . . . . 25

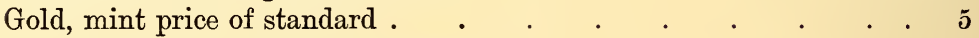

,, standards at various epochs for . . . . . . . 4

,, value of various qualities of . . . . . . . . . . 5

Goldsmiths, lists of French _ . . . . . . 25, 29, 48, 99

Gramme weights . . . . . . . . . . . 2 2

,,$"$ compared with Troy, etc. . . . . . 3

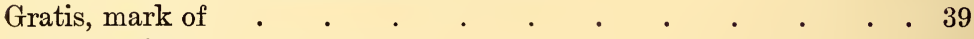

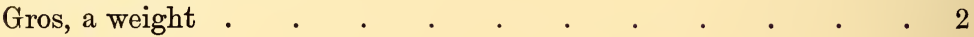


H.

$\mathrm{H}$, mint letter of La Rochelle

PAGE

Hall-marks, origin of

I.

I, Limoges mint letter . $\quad$. $\quad$. c . . . . . . 64

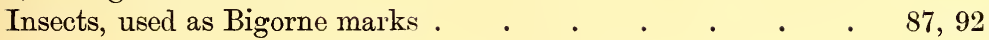

J.

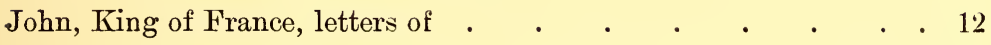

K.

$\mathrm{K}$, Bordeaux mint letter 64,66

L.

L, Bayonne mint letter . . . . . . . . . . 64

Lacroix's Histoire de l'Orfèvererie, \&c. . . . 28, 35, 67

Le Roy, Pierre, code compiled by . . . . . . . . . 33

Letters, initial and other, used as town marks . . . $\quad 52,54,64$ „ mint, used as plate marks . . . . . . . 27, 38

" tables of alphabetical year . . . . . . . 40

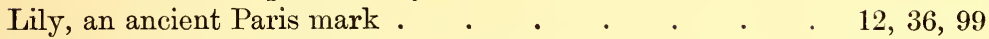

Limoges, the cradle of the goldsmiths' art . . . . . . 7

Lorraine, standards used in . . . . . . . $57,74,76$

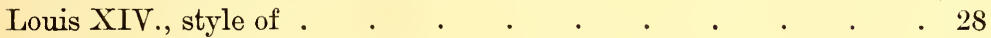

„, XV., style of . . . . . . . . . . 30

", XVI., style of . . . . . . . . . . . . . . 32

Louvre, school of the . . . . . . . . . . . . 25

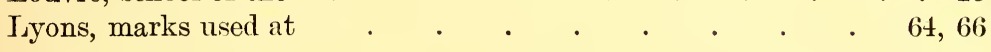

M.

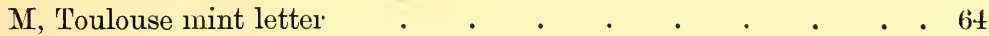

Maker's mark, regulations respecting _ _ . . . 13, 28, 38, 83

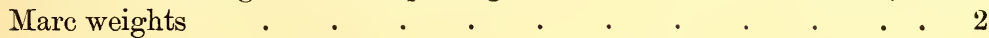

, , $\quad$ compared with Troy, etc. . . . . . . . . 3

Marks, when first mentioned . . . . . . . . . 11

Metric system, weights of the.$\quad$. $\quad$. . . . . . . 3

Millesimal notation, introduction of . . . . . . . . . 2

Mint letters as marks, use of . . . . . . . 27, 28

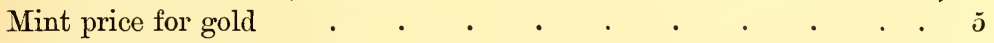

Montpellier, records of

, ancient marks used at $\quad . \quad . \quad . \quad$. $46,52,57$ 
N.

$\mathrm{N}$, Montpellier mint letter

0.

0 , Riom mint letter

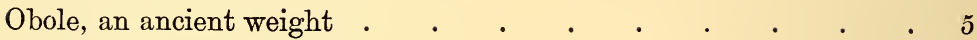

Or de touche . . . . . . . . . . . . 4, 44

P.

P, Dijon mint letter .

$\mathrm{P}$ crowned, a Paris mark $\quad . \quad$. $\quad . \quad$. $\quad . \quad$. $\quad . \quad$. 36,39

Paris, early mention of goldsmiths in . . . . . . 8

„, date-letters used at . . . . . . . . . 40

„ mint letter for . . . . . . . $27,38,45,64,66$

, touch of . . . . . . . . . . . 4

Philippe le Hardi, ordinances of . . . . . . . . 11

, le Bel, ordinances of . . . . . . . . . 11

Plate, destruction of, at various times _ . . . . . 26, 33

Provincial marks, alphabetical lists of . _ _ _ . 5 58, 93,97

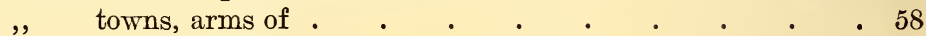

", " marks used in . . . . . . . . . 51

,, mint letters of various . . . . 27, 54,64

Puy-en-Velay, the goldsmiths of . . . . . . . . . 15, 62

Q.

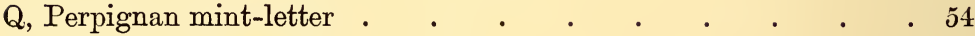

R.

R, Orleans mint letter • • • . . . . . . . 64

Recense, what . . . . . . . . . $84,88,89$

Regency, style of the . . . . . . . . . . 30

Remarque, mark for gold chains . . . . . . . . 87

Remedy, what . . . . . . . . . $5,6,14$

Renaissance, effect of the . . . . . . . . . . 22

Republic, marks introduced under the . . . . . . 82,88

Rosnel, Pierre de . . . . . . . . . . . . . 19

Rouen, the goldsmiths of . . . . . . . . . . 52

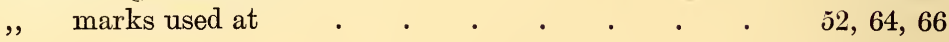

S.

$\mathrm{S}$, Chalons mint letter •

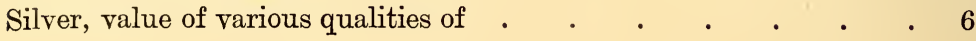


Solignac, the monks of .

St. Eloi, patron of the goldsmiths . . . . . . . . 7

St. Martial, first patron of the craft . . . . . . . 7

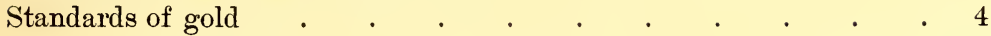

, $\quad$ provincial . . . . . . . . . . . 56

,, silver . . . . . . . . . . . . 5

Sumptuary legislation . . . . . . . . . . . . . 12,30

T.

T, Nantes mint letter . . . . . . . . . . 54

Tables of old Paris marks . . . . . . . . . . . 45

,. , provincial marks . . . . . . . 57, 58-81, 93, 97

,, modern marks . . . . . . . . . . . . . . . . . . . . . .

Tours, the goldsmiths of . . . . . . . . . . . . 15,64

Town marks, lists of . . . . . . . . . . . . . 58,67

Trinity, Hospital of the . . . . . . . . . . . . 34, 38

Troy weight, compared with mares, etc. . . . . . . . . 3

Troyes, the goldsmiths of . . . . . . . . . 15

$\nabla$.

$\mathrm{V}$, an Amiens mint letter . . . . . . . . . . . . 54

Verification marks, when used . . . . . . . . 84

IV.

W, a Lille mint letter . . . . . . . . . . 54

Wardens, early mention of . . . . . . . . . . 12

,, their duties, etc. . . . . . . . . . 16,20

Watches, marks for . . . . . . . . . . . . 96

X.

X, an Amiens and Soissons mint letter . . . . . . . . 64

Y.

Y, Bourges mint letter

\%.

$\mathrm{Z}$, Grénoble mint lettel 


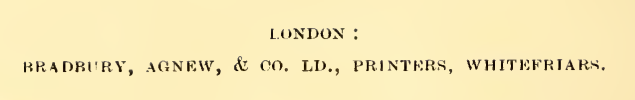



SMITHSONIAN INSTITUTION LIBRARIES

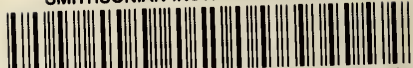

39088003397684 chm NK7149.C8 18932

Old French plate, 